\title{
Appraisal of Ground-Water Quality in the Bunker Hill Basin of San Bernardino Valley, California
}

By Lowell F.W. Duell, Jr., and Roy A. Schroeder

\section{U.S. GEOLOGICAL SURVEY}

Water-Resources Investigations Report 88-4203

Prepared in cooperation with the

SAN BERNARDINO VALLEY MUNICIPAL WATER DISTRICT 
DEPARTMENT OF THE INTERIOR

MANUEL LUJAN, JR., Secretary

U.S. GEOLOGICAL SURVEY

Dallas L. Peck, Director

\footnotetext{
For additional information write to:

District Chief

U.S. Geological Survey

Federal Building, Room W2234

2800 Cottage Way

Sacramento, CA 95825
}

Copies of this report

can be purchased from:

U.S. Geological Survey

Books and Open-File Reports Section

Federal Center, Building 810

Box 25425

Denver, CO 80225 
CONTENTS

Page

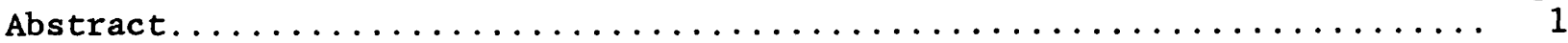

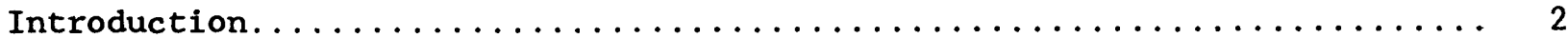

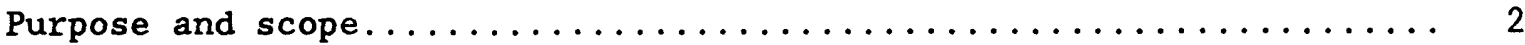

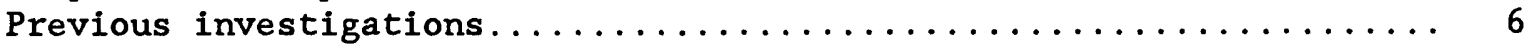

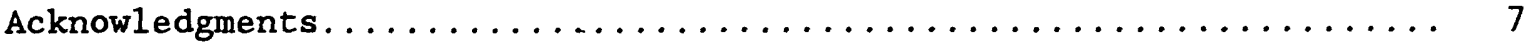

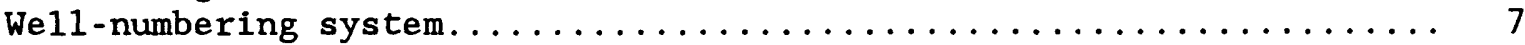

Description of study area.............................. 8

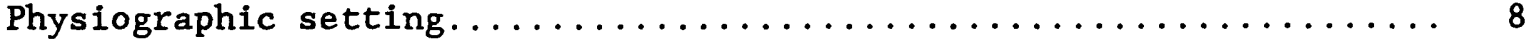

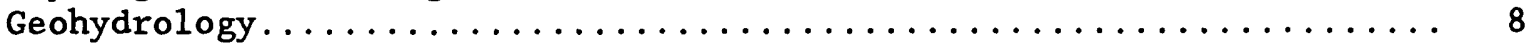

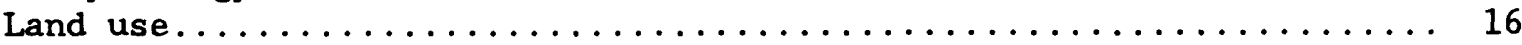

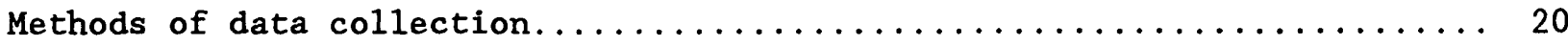

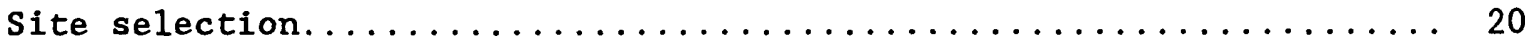

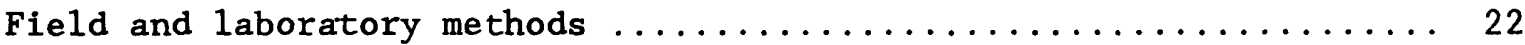

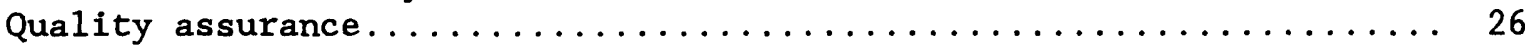

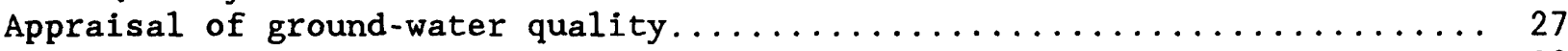

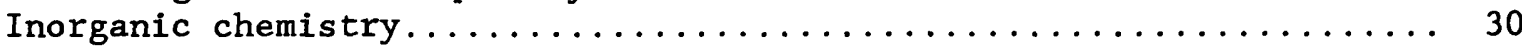

Inorganic-constituent concentrations............... 30

Relation to land use and aquifer.................... 32

Historical trends............................ 33

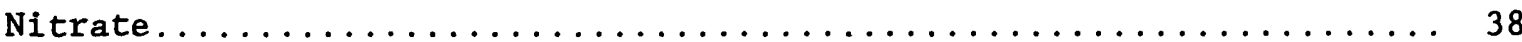

Nitrate concentration........................ 38

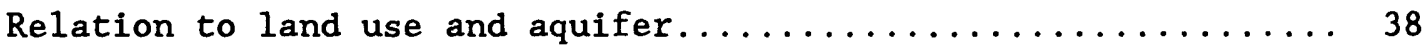

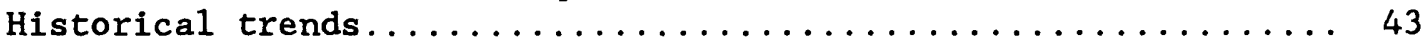

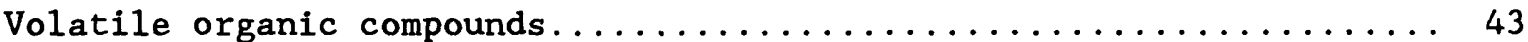

Quality-assurance results..................... 46

Volatile-organic-compound concentrations.............. 48

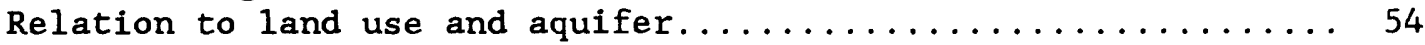

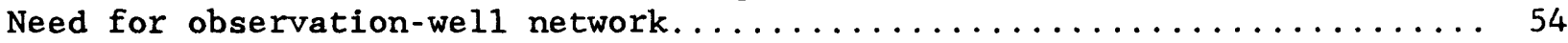

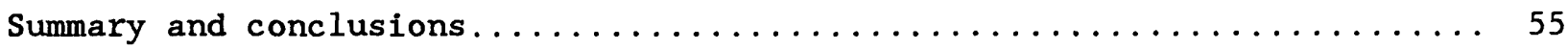

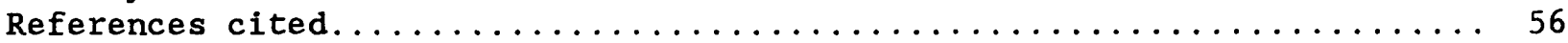

Supplemental data: Physical and chemical data for wells........... 58 
Figures 1-3. Maps showing:

Page

1. Location of study area................... 3

2. Ground-water basins in San Bernardino Valley......... 4

3. Generalized geology...................... 10

4. Geologic sections $A-A^{\prime}$ and $B-B^{\prime} \ldots \ldots \ldots \ldots \ldots \ldots \ldots \ldots \ldots \ldots \ldots$

5-10. Maps showing:

5. Altitude of potentiometric surface and direction of ground-water movement, summer $1986 \ldots \ldots \ldots \ldots \ldots 14$

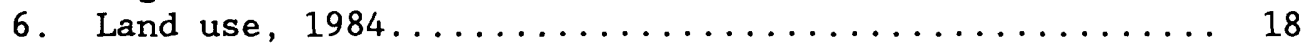

7. Location of wells sampled.................. 24

8. Distribution of dissolved solids in ground water,

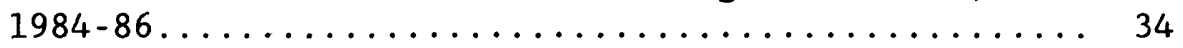

9. Chemical quality of water from selected wells....... 36

10. Nitrate concentration in water from selected wells,

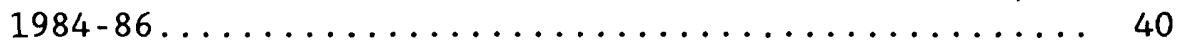

11. Graph showing distribution of nitrate concentration compared to depth of well-perforation interval............ 42

12-14. Maps showing:

12. Comparison of present (1986) and historical nitrate concentration in water from selected wells....... 44

13. Tetrachloroethylene concentration in water from

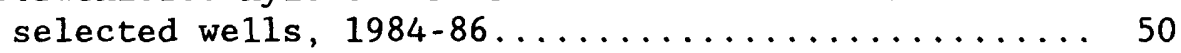

14. Trichloroethylene concentration in water from selected

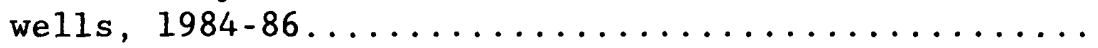

\section{TABLES}

Table 1. Wells used for water-quality sampling............... 21

2. Water-quality constituents analyzed for this study......... 23

3. Maximum contaminant levels for domestic drinking water....... 28

4. Selected data for statistical analysis, $1988 \ldots \ldots \ldots \ldots \ldots \ldots$

5. Concentration of selected inorganic constituents in samples from wells in the upper and lower aquifers, $1988 \ldots \ldots \ldots \ldots \ldots \ldots 33$

6. Summary statistics of recovery rate on surrogate spikes for 52 samples analyzed for volatile organic compounds.......... 46

7. Volatile-organic-compound concentrations in duplicate samples,

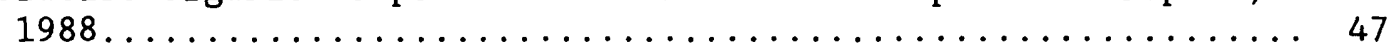

8. Frequency of detection, highest concentration, and well having the highest concentration of volatile organic compounds..... 49

9. Wells and locations for potential ground-water quality observation-well network..................... 55 
For readers who prefer to use metric (International System) units rather than inch-pound units, the conversion factors for the terms used in this report are listed below:

Multiply inch-pound unit

acre

acre-foot (acre-ft)

acre-foot per year

(acre-ft/yr)

foot ( $f t$ )

foot per mile ( $\mathrm{ft} / \mathrm{mi}$ )

inch (in.)

mile (mi)

ounce, fluid (fl. oz)

ounce, avoirdupois (oz)

square mile $\left(\mathrm{mi}^{2}\right)$
To obtain metric unit hectare

cubic hectometer

cubic hectometer per annum

meter

meter per kilometer

millimeter

micrometer $(\mu \mathrm{m})$

kilometer

milliliter (mL)

microgram

square kilometer

Abbreviations used:

DBCP - dibromochloropropane

PCE - tetrachloroethylene

TCE - trichloroethylene

Temperature is given in degrees Celsius $\left({ }^{\circ} \mathrm{C}\right)$, which can be converted to degrees Fahrenheit $\left({ }^{\circ} \mathrm{F}\right)$ by using the following equation:

Temp. ${ }^{\circ} \mathrm{F}=1.8$ (temp. $\left.{ }^{\circ} \mathrm{C}\right)+32$.

Chemical concentration is given in milligrams per liter (mg/L) or micrograms per liter $(\mu \mathrm{g} / \mathrm{L})$. Milligrams per liter is a unit expressing the solute per unit volume (liter) of water. One thousand micrograms per liter is equivalent to one milligram per liter. For concentrations less than 7,000 $\mathrm{mg} / \mathrm{L}$, the numerical value in milligrams per liter is about the same as for concentrations in parts per million (ppm), and the numerical value in micrograms per liter is about the same as for concentrations in parts per billion ( $\mathrm{ppb}$ ).

Specific conductance is given in microsiemens per centimeter $(\mu \mathrm{s} / \mathrm{cm})$ at $25^{\circ} \mathrm{C}$. Microsiemens per centimeter is numerically equal to micromhos per centimeter.

Sea leve1: In this report "sea level" refers to the National Geodetic Vertical Datum of 1929 (NGVD of 1929)--a geodetic datum derived from a general adjustment of the first-order level nets of both the United States and Canada, formerly called Sea Level Datum of 1929. 


\section{APPRAISAL OF GROUND-WATER QUALITY IN THE BUNKER HILL BASIN}

OF SAN BERNARDINO VALLEY, CALIFORNIA

By Lowell F.W. Duell, Jr., and Roy A. Schroeder

\section{ABSTRACT}

Increasing population and an associated shift from agricultural to urban land use in the Bunker Hill basin of San Bernardino Valley, California, have caused increasing concern about the ground-water quality in the basin. Forty-seven wells were sampled during 1986 and analyzed for the concentration of major inorganic ions, nitrogen species, and volatile (purgeable) organic priority pollutants to address this concern. Data from this study were supplemented with additional analyses of nitrate, tetrachloroethylene, and trichloroethylene concentrations determined by other agencies.

The inorganic quality of ground water in the basin generally was suitable for most uses during 1986, although fluoride concentration exceeded the California public drinking-water standard of 1.4 milligrams per liter in water from 5 of the 47 wells that were sampled.

Nitrate (as nitrogen) concentration equaled or exceeded the public drinking-water standard of 10 milligrams per liter in water from 13 of 47 wells sampled for this study and in an additional 19 of 120 samples analyzed by other agencies. Concentration generally decreased with increasing depth below land surface. No relation between nitrate concentration and land use was found, and no basinwide trend in concentration since 1955 was evident.

Twenty-four of the 33 volatile organic priority pollutants were detected in water from wells sampled during this study. When supplemental data from other agencies are included, tetrachloroethylene concentration was found to exceed California's interim advisory standard (action level) of 4 micrograms per liter in water from 36 of 134 wells, and trichloroethylene concentration exceeded the standard of 5 micrograms per liter in water from 49 of 138 wells. No basinwide relation between contamination by these two chemicals and well depths or land use was discerned; however, the two chemicals were commonly detected in ground water in central Redlands and northwest San Bernardino.

A network of 11 observation wells that could be sampled twice yearly and 47 wells that could be sampled once every 5 years would enhance the monitoring of changes in ground-water quality in the Bunker Hill basin. 
Ground water is the principal source of public water supplies in the Bunker Hill ground-water basin (hereafter referred to as the Bunker Hill basin) (fig. 1), which is about 60 miles east of Los Angeles in southern California. Land use and water use in the basin are rapidly changing from agricultural to urban, and domestic consumption has increased. Because of these recent developments, ground-water-quality problems have become a concern to residents and water-supply agencies. The principal ground-water-quality problems in 1977-80 were high nitrate and fluoride concentrations. Since then, commonly used industrial solvents, such as tetrachloroethylene (PCE) and trichloroethylene (TCE), have been detected in ground water of the basin. In addition, dibromochloropropane (DBCP), an agricultural fumigant, has been reported in ground water from the Redlands area in the southeast part of the basin.

A rising water table in the Bunker Hill basin could introduce contaminants contained in the unsaturated zone to the saturated zone. Previous investigators (Klein and Bradford, 1980, p. 64) projected a worst case scenario in which the concentration of nitrate as nitrogen $\left(\mathrm{NO}_{3}-\mathrm{N}\right)$ in ground water could reach as high as $66 \mathrm{mg} / \mathrm{L}$ in the Highland-East Highlands area in the east-central part of the basin. A similar calculation for the Redlands area (Klein and Bradford, 1979, p. 73) indicated that the concentration of $\mathrm{NO}_{3}-\mathrm{N}$ could reach as high as $48 \mathrm{mg} / \mathrm{L}$ if the water levels rose to within 50 feet of land surface. Because of decreases in pumpage of local water for agricultural irrigation, recent above-average rainfall, and artificial recharge of water imported from outside the basin, ground-water levels again are high in the former swampland area of the Bunker Hill basin (fig. 2). Therefore, current water-quality conditions need to be compared with historical data to determine whether changes have occurred. In addition, an assessment of water quality in the basin might aid in defining ground-water flow and recharge patterns and could provide local water districts with information needed to provide water of a given quantity while maintaining adequate quality. The U.S. Geological Survey, in cooperation with the San Bernardino Valley Municipal Water District, began a ground-water-quality assessment of the Bunker Hill basin in 1986.

\section{Purpose and Scope}

This report describes current (1986) ground-water-quality conditions, compares current to historical ground-water quality, and describes a ground-water-quality observation-well network for the basin. The scope of the study included analysis of major inorganic ions in water samples from 46 wells, nitrate in samples from 47 wells, and volatile (purgeable) organic compounds in samples from 45 wells. In addition, water-quality data collected by other agencies from more than 100 wells also were reviewed. 


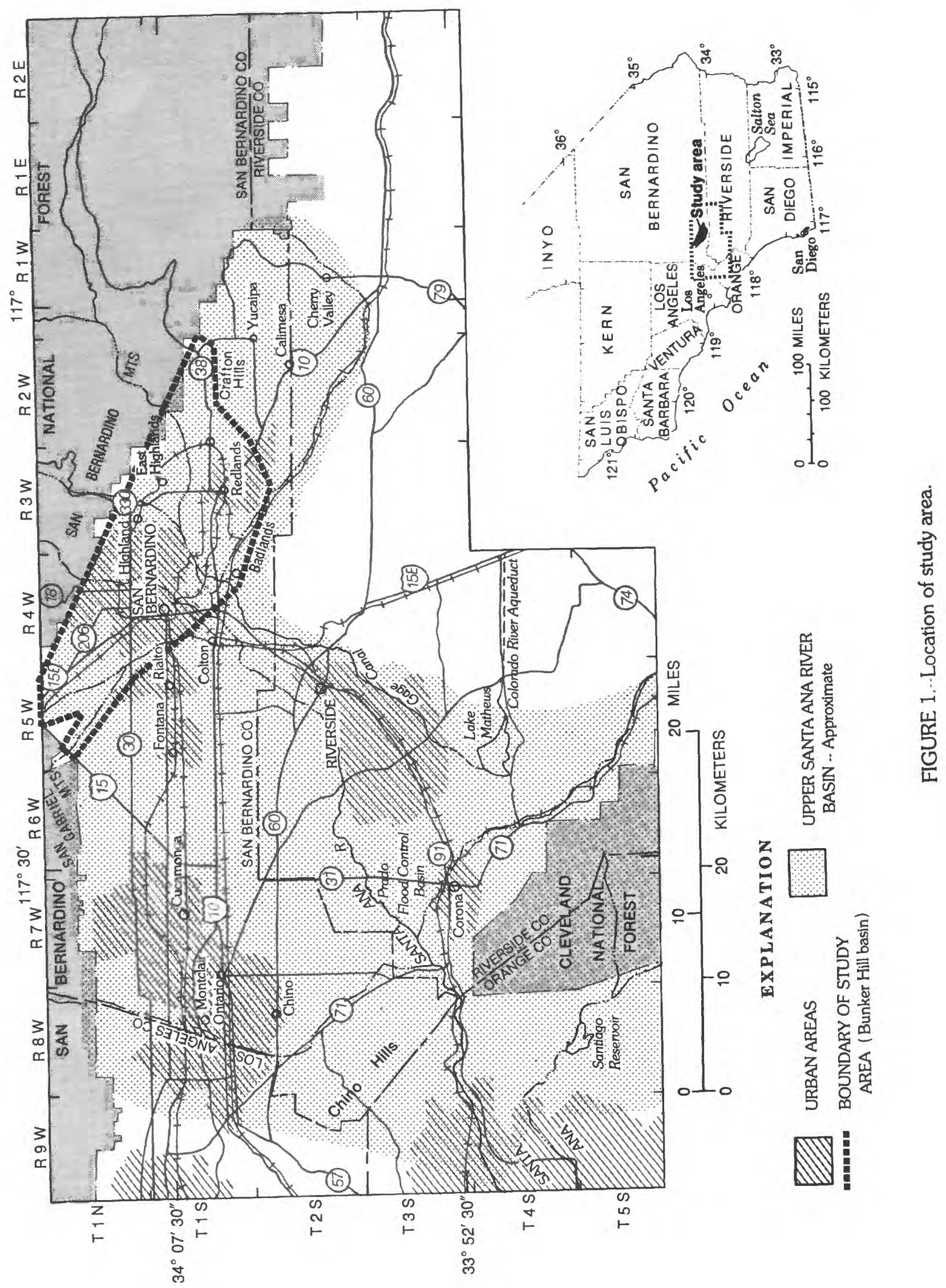




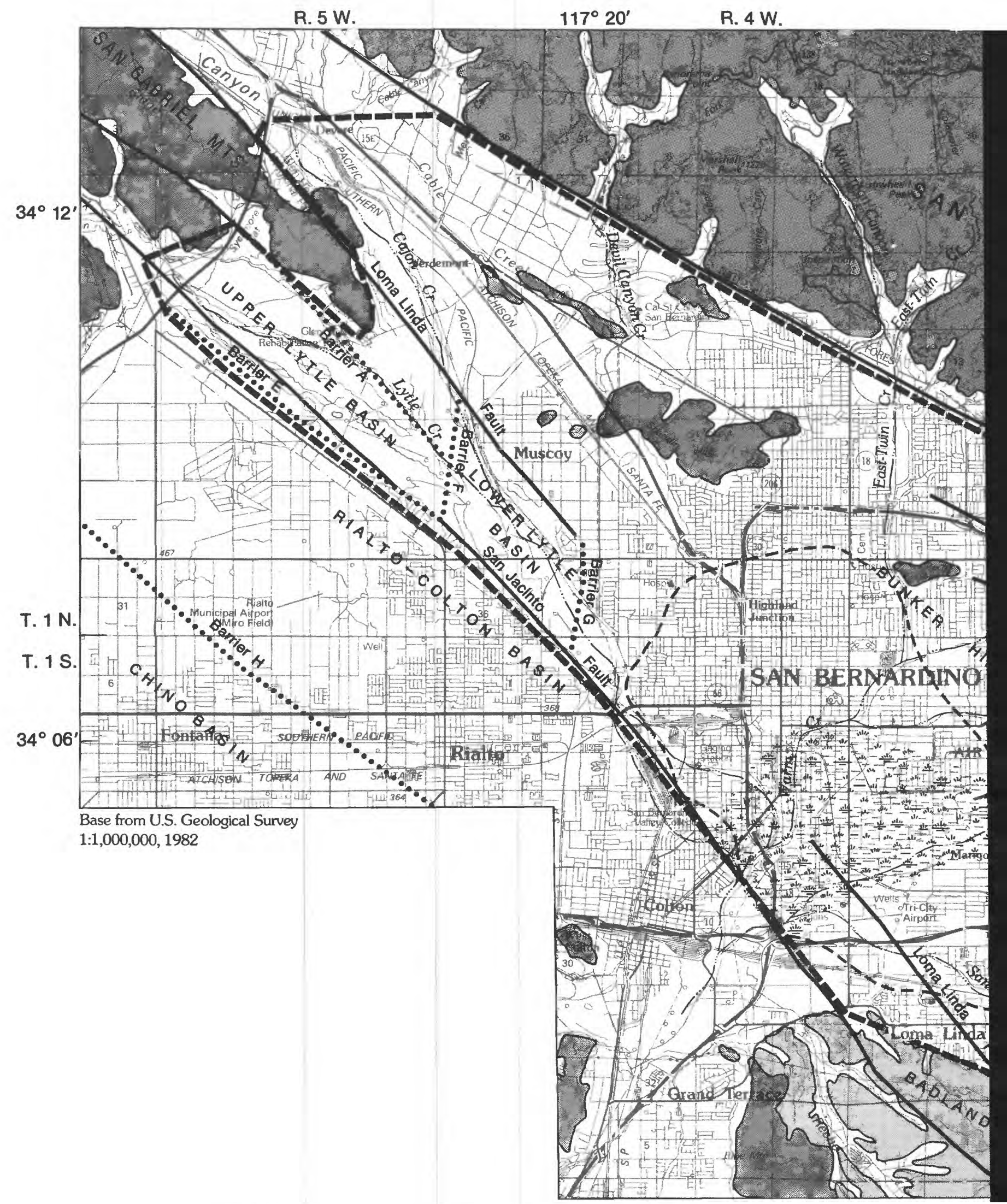

FIGURE 2.--Ground-water basins in San Bernardino Valley. 
0
0

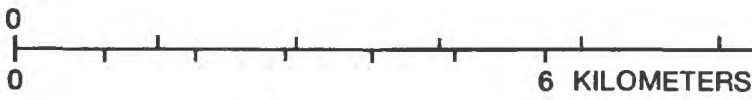

6 MILES

R 3 W $117^{\circ} 10^{\prime}$

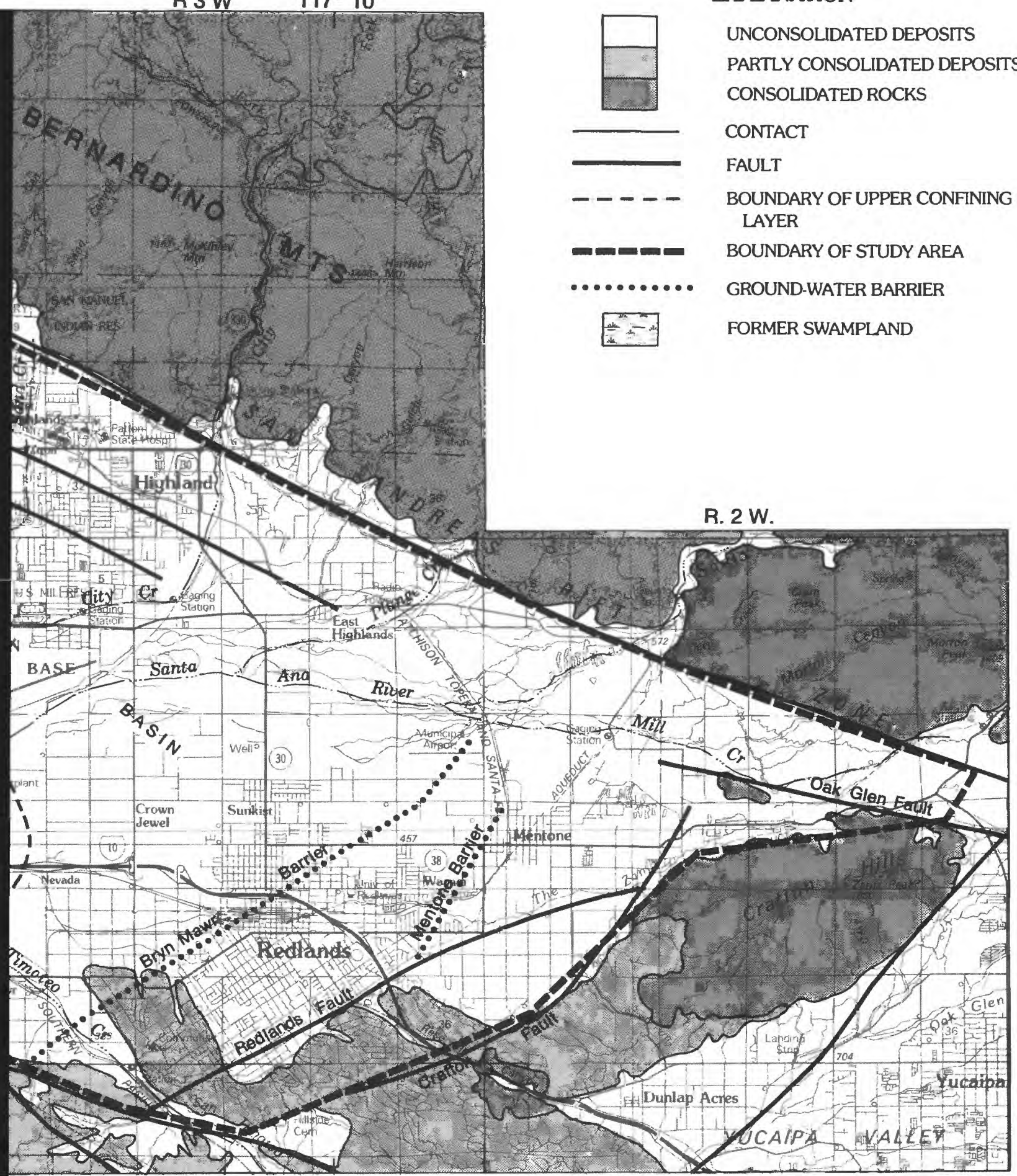

Geology modified from Dibblee $(1963,1968)$ and Dutcher and Garrett $(1963)$ 
This report includes (1) water-quality data that indicate where constituents exceeded public-health standards; (2) illustrations that show areal distribution of ground-water quality, with emphasis on dissolved solids, nitrate, PCE, and TCE; (3) identification of factors that might affect groundwater quality, such as land use, recharge, and geology; (4) comparison of current and historical ground-water quality; and (5) description of an observation-well network that could be used to identify future ground-water-quality changes in the basin.

\section{Previous Investigations}

Extensive descriptions of the geology, hydrology, and ground-water chemistry are given for the Redlands area, in the southeast part of the Bunker Hill basin, by Burnham and Dutcher (1960) and for the San Bernardino area, in the west-central part of the basin (fig. 2), by Dutcher and Garrett (1963). Furthermore, they identified sources of recharge and discharge, and delineated subbasin boundaries on the basis of the presence of flow barriers (faults). Geologic sections and recharge and discharge values for the basin are given by Hardt and Hutchinson (1980).

Nitrate contamination in the Bunker Hill basin has been reported in several previous studies. Eccles (1979) identified high nitrate concentrations in some wells of the Bunker Hill basin during a general assessment of ground-water quality in the upper Santa Ana River basin, of which Bunker Hill basin is a part (fig. 1). The distribution of nitrate in ground water in the Redlands area was determined by Eccles and Bradford (1977, p. 25) to be dependent primarily on depth below the water table. Eccles and Klein (1978) reported the results of a similar study in the Highland-East Highlands area, in the east-central part of Bunker Hill basin. Studies to quantify and delineate the distribution of nitrate and other forms of nitrogen in the unsaturated zone were done by Klein and Bradford (1979) for the Redlands area and Klein and Bradford (1980) for the Highland-East Highlands area.

Historical data on contamination by volatile organic compounds in the Bunker Hill basin are sparse. The California Department of Health Services first detected PCE and TCE contamination during a 1980 basinwide water-quality survey (California Department of Health Service, written commun., 1986). Since then, sampling for PCE and TCE has been required for public water-supply wells in the basin, and these data were made available for this study (California Department of Health Services and California Regional Water Quality Control Board (Santa Ana Region), written commun., 1986). The URS Corporation (1986) compiled a list of possible sources of PCE and TCE in the northwest part of the basin and identified areas of contamination on the basis of analysis of soil-pore gas.

A generalized map shows land use in 1976 in the Highland-East Highlands area (Eccles and Klein, 1978), and a similar map shows land use in 1975 in the Redlands area (Klein and Bradford, 1979). A 1984 survey by the California Department of Water Resources of the upper Santa Ana River drainage area provides detailed land-use information for the Bunker Hill basin on 1:24,000-scale U.S. Geological Survey topographic maps (California Department of Water Resources, 1985). 


\section{Acknowledgments}

For help in collecting the water samples and well data used in this study, appreciation is expressed to employees of the cities of San Bernardino, Redlands, Loma Linda, and Riverside; to employees of San Bernardino Valley Municipal Water District, California Regional Water Quality Control Board (Santa Ana Region), California Department of Health Services, Gage Canal Company, Patton State Hospital, Southern California Water Company, East Valley Water District, and Southern California Edison; and to numerous private citizens.

\section{We11-Numbering System}

Wells are numbered according to their location in the rectangular system for subdivision of public 1and. For example, in well number $1 \mathrm{~S} / 3 \mathrm{~W}-21 \mathrm{H} 7$, that part of the number preceding the slash indicates the township (T. 1 S.); the number and letter following the slash indicate the range (R. $3 \mathrm{~W}$.$) ; the number$ following the hyphen indicates the section (sec. 21); and the letter (H) indicates the 40-acre subdivision of the section according to the lettered diagram below. The final digit (7) is a serial number for wells in each 40-acre subdivision. The area covered by this report lies in the northwest and southwest quadrants of the San Bernardino base line and meridian. Township and range are given along the margin of maps, and thus wells on maps are identified by the section number and the letter of the 40-acre subdivision in that section. The computer-tabulated well numbers in table 1 and in the supplemental data section are 14-character State well numbers in which unused spaces and the slash are replaced with zeros, and the hyphen is excluded. For example, well $1 \mathrm{~S} / 3 \mathrm{~W}-21 \mathrm{H} 7$ is identified in table 1 and in the supplemental data section at the end of this report as 0015003W21H07s. The final letter (S) indicates the San Bernardino base line and meridian.

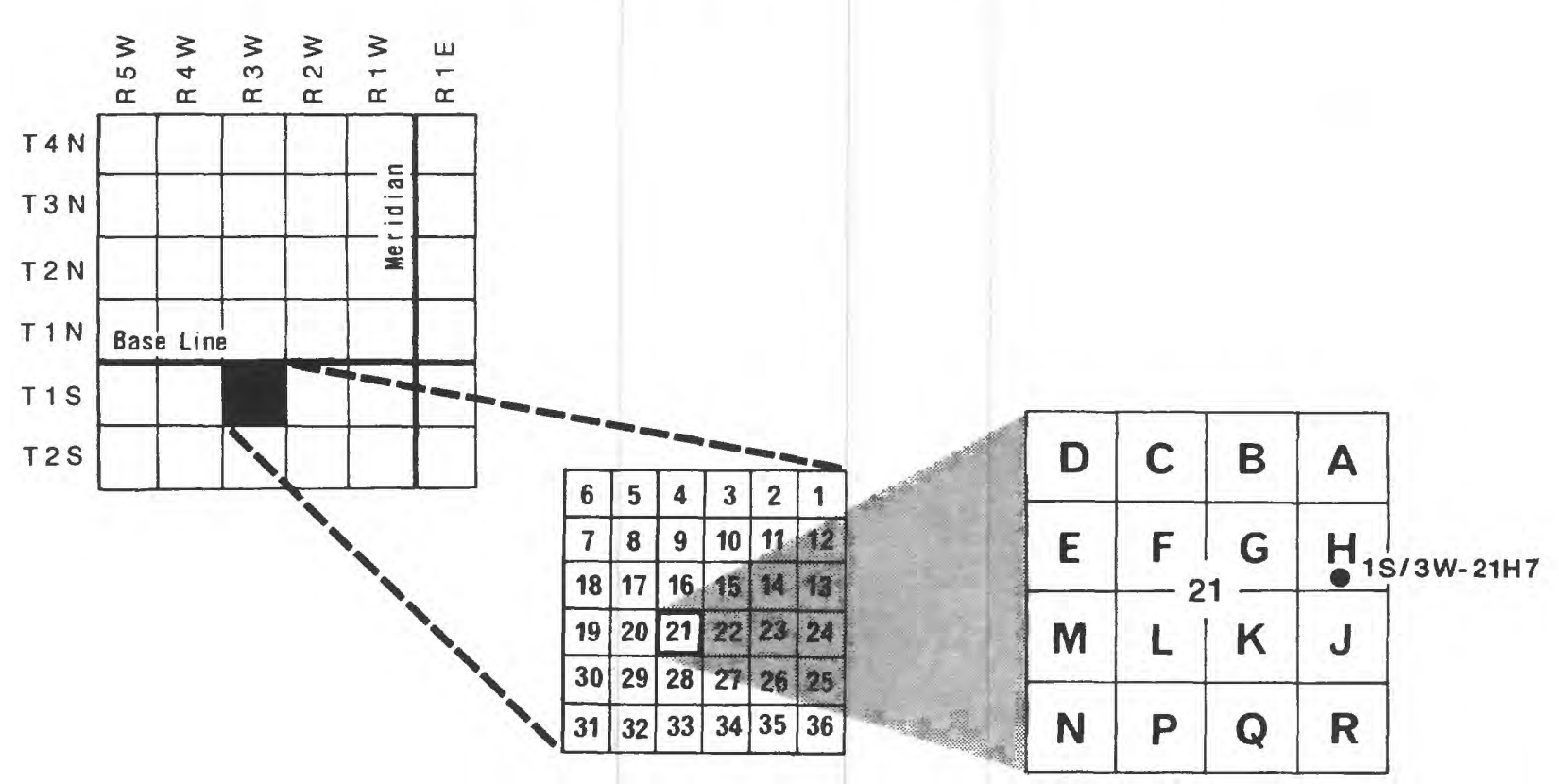




\section{Physiographic Setting}

The area of this study, the Bunker Hill basin, is entirely within the San Bernardino Valley. The basin occupies approximately $120 \mathrm{mi}^{2}$ between the San Andreas and San Jacinto faults. It is bounded on the northwest by the San Gabriel Mountains, on the northeast by the San Bernardino Mountains, on the south by the Badlands and the Crafton Hills, and on the southwest by a low east-facing escarpment of the San Jacinto fault (fig. 2). The land surface slopes generally downward to the southwest; gradients range from 75 to 150 $\mathrm{ft} / \mathrm{mi}$ on the edges of the basin and from 30 to $50 \mathrm{ft} / \mathrm{mi}$ in the central part.

Climate in the Bunker Hill basin is semiarid and is characterized by relatively dry, warm summers and cool, wet winters. Data collected at U.S. National Oceanic and Atmospheric Administration stations show that temperatures commonly exceed $40{ }^{\circ} \mathrm{C}$ during summer and occasionally are below freezing in the winter. In addition, mean annual precipitation ranges from 12 inches in the Badlands to 25 inches at the base of the San Bernardino and San Gabriel Mountains.

\section{Geohydrology}

Dutcher and Garrett (1963) identified the principal ground-water basins in the San Bernardino Valley as Bunker Hill, Rialto-Colton, upper and lower Lytle, and Chino (fig. 2). Faults across the valley form barriers that restrict, to varying degrees, the movement of ground water through unconsolidated deposits that fill the basins. Faults are inferred from topographic and water-level data; other barriers are inferred from water-level differences in wells. Water-level differences across these faults and barriers are 50 feet or more. Some faults are only partial barriers to ground-water movement; examples are (some sections of) the Loma Linda fault in the southern part of the basin and fault $K$ in the northern part. Ground water flows from the upper and lower Lytle basins into the Bunker Hill basin; therefore, this study includes some data from these basins (fig. 2). Ground-water flow from the Bunker Hill basin discharges mostly to the southwest across the San Jacinto fault and into the Rialto-Colton basin. 
The generalized geology of the Bunker Hill basin is shown in figure 3 . According to Dutcher and Garrett (1963), the unconsolidated material that fills the basin includes river-channel deposits and younger alluvium, both of Holocene age, and older alluvium (including terrace deposits and fanglomerates) of Pleistocene age. Partly consolidated material in the basin includes continental deposits of Quaternary and Tertiary age. A basement complex of Precambrian igneous and metamorphic rocks underlies the unconsolidated and partly consolidated deposits and crops out in the surrounding mountain ranges.

The water-bearing material in the basin consists of alluvial deposits of sand, grave1, and boulders interspersed with lenticular deposits of silt and clay. The maximum depth to bedrock is greater than 1,400 feet below land surface along the northeast side of the San Jacinto fault south of San Bernardino (fig. 3); the basin deposits become progressively thinner toward the surrounding mountains. Adjacent to the San Jacinto fault, the unconsolidated deposits contain numerous clay layers that act as leaky confining beds.

Although individual sand and clay layers in the basin generally can be correlated for only short distances, Dutcher and Garrett (1963), using lithologic information in drillers' logs, distinguished three aquifers (upper, middle, and lower), each separated by 50 to 300 feet of clay and silt. Hardt and Hutchinson (1980) divided the same water-bearing material into two aquifers (upper and lower) on the basis of lithologic information, electric logs, and water levels in a test hole that was drilled to bedrock in the middle of the basin. The middle and lower aquifers of Dutcher and Garrett (1963) were combined and referred to as the lower aquifer by Hardt and Hutchinson. For the purpose of this study, the Hardt and Hutchinson (1980) concept of a two-layer aquifer system was used. In the central part of the basin, upgradient from the San Jacinto fault, a poorly permeable clay layer, which is called the upper confining layer (fig. 3), creates confined conditions in the lower aquifer over an area of about $25 \mathrm{mi}^{2}$. The area of confined water in the lower aquifer is not static but varies depending on the variations in inflow-outflow relations.

Thickness of the upper and lower aquifers and depth of the confining layer that separates them are illustrated on the generalized geologic sections in figure 4. Maximum thickness of the upper aquifer is approximately 350 feet, and maximum thickness of the lower aquifer is approximately 650 feet. Section A-A' (fig. 4) indicates that the confining layer separating the upper and lower aquifers disappears near the northeast margin of the basin at the mountains.

Figure 4 also indicates the presence of a near-surface deposit of low hydraulic conductivity that creates a shallow water-bearing zone in about 10 $\mathrm{mi}^{2}$ of the former swampland near the confluence of Warm Creek and the Santa Ana River (fig. 2). The upper aquifer is confined within this area. 


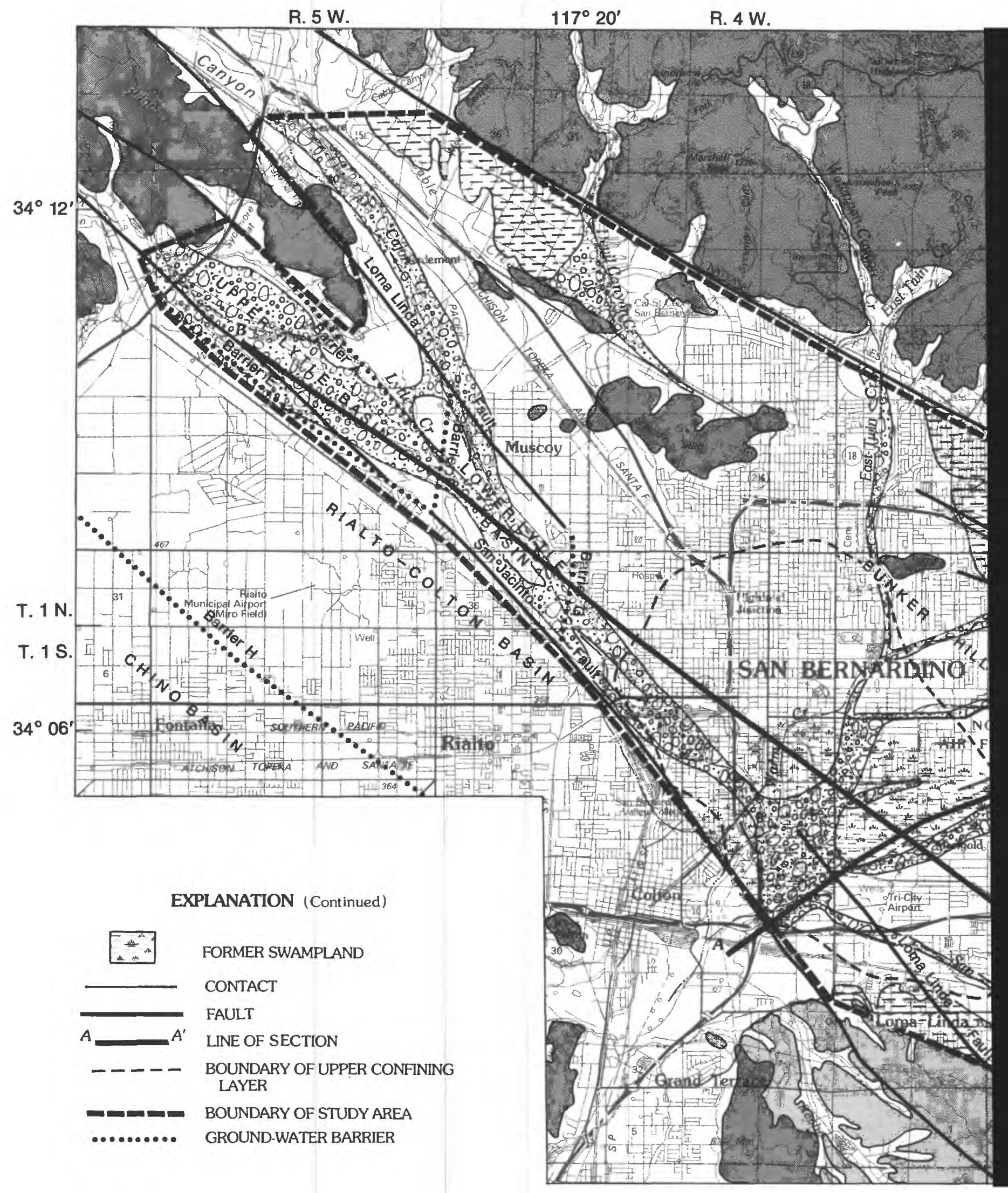

FIGURE 3.--Generalized geology. 


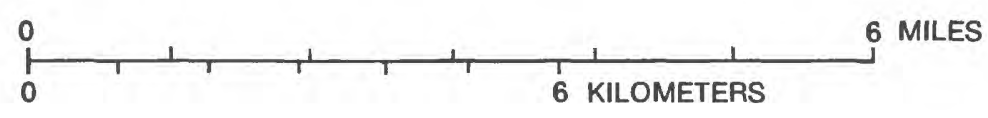

\section{EXPLANATION}

UNCONSOLIDATED DEPOSITS--

RIVER-CHANNEL DEPOSITS OF HOLOCENE AGE--

Unconsolidated boulders, coarse gravel, sand and silt in major river channels; highly permeable, largely unsaturated, but transmit large seepage losses from river and streams to main aquifer

YOUNGER ALLUUIUM OF HOLOCENE AGE. Unconsolidated boulders, coarse gravel, sand, silt, and clay; highly permeable, and yields water copiously to wells

OLDER ALLUVIUM OF PLEISTOCENE AGE--Unconsolidated boulders, coarse gravel, sand, silt, and clay; locally contains clay beds; fractured and folded in places; yields water copiously to wells that penetrate permeable deposits

PARTLY CONSOLIDATED DEPOSITS

CONTINENTAL DEPOSITS OF QUATERNARY AND TERTIARY AGE-- Unconsolidated to compacted gravel, sand, silt, and clay; yield water in moderate quantities to wells that penetrate permeable deposits

CONSOLIDATED ROCKS

BASEMENT COMPLEX OF PRECAMBRIAN AGE--

Consolidated metamorphic and igneous rocks; virtually non-water bearing

\section{R. 2 W.}

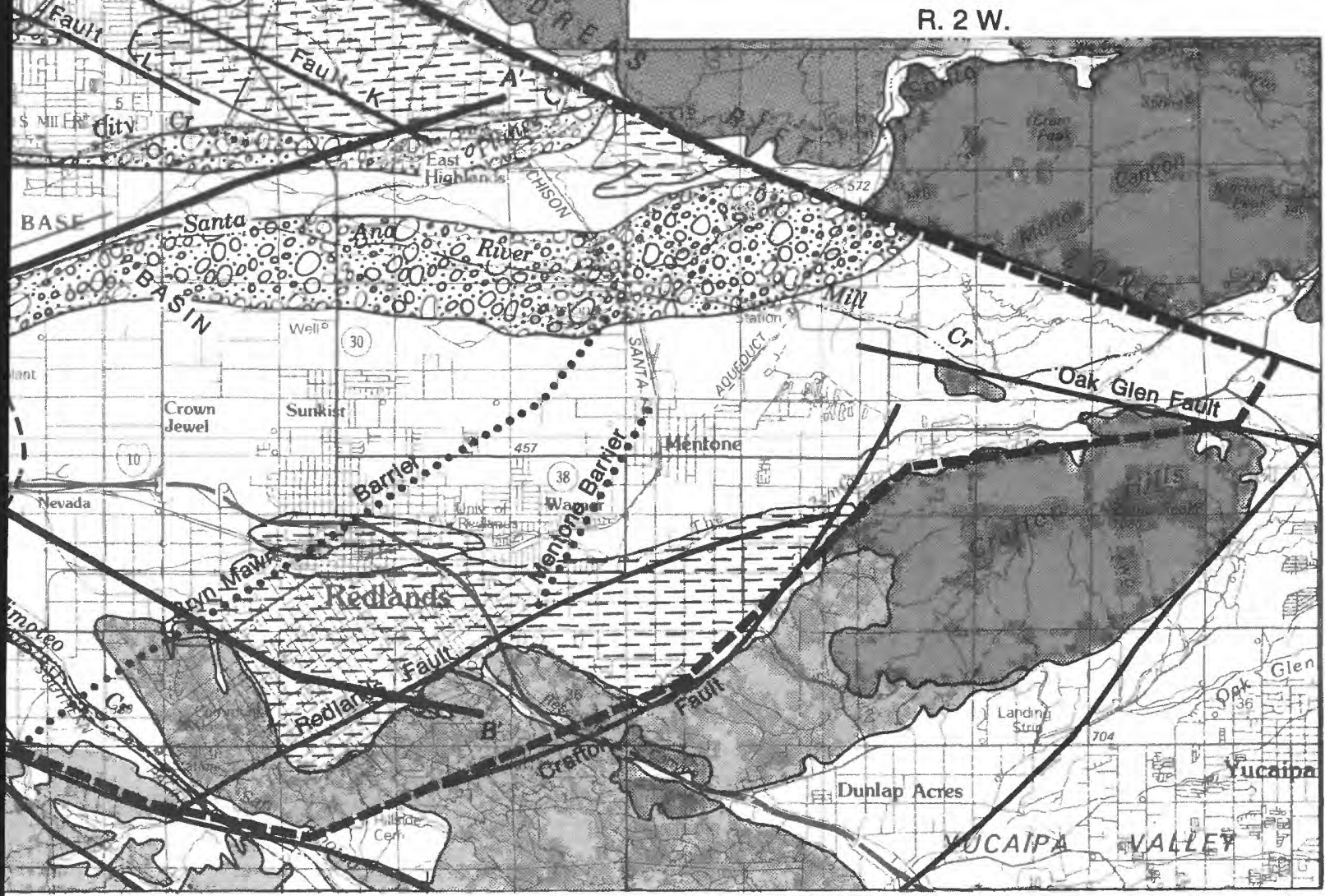

Geology modified from Dibblee $(1963,1968)$ and Dutcher and Garrett $(1963)$ 

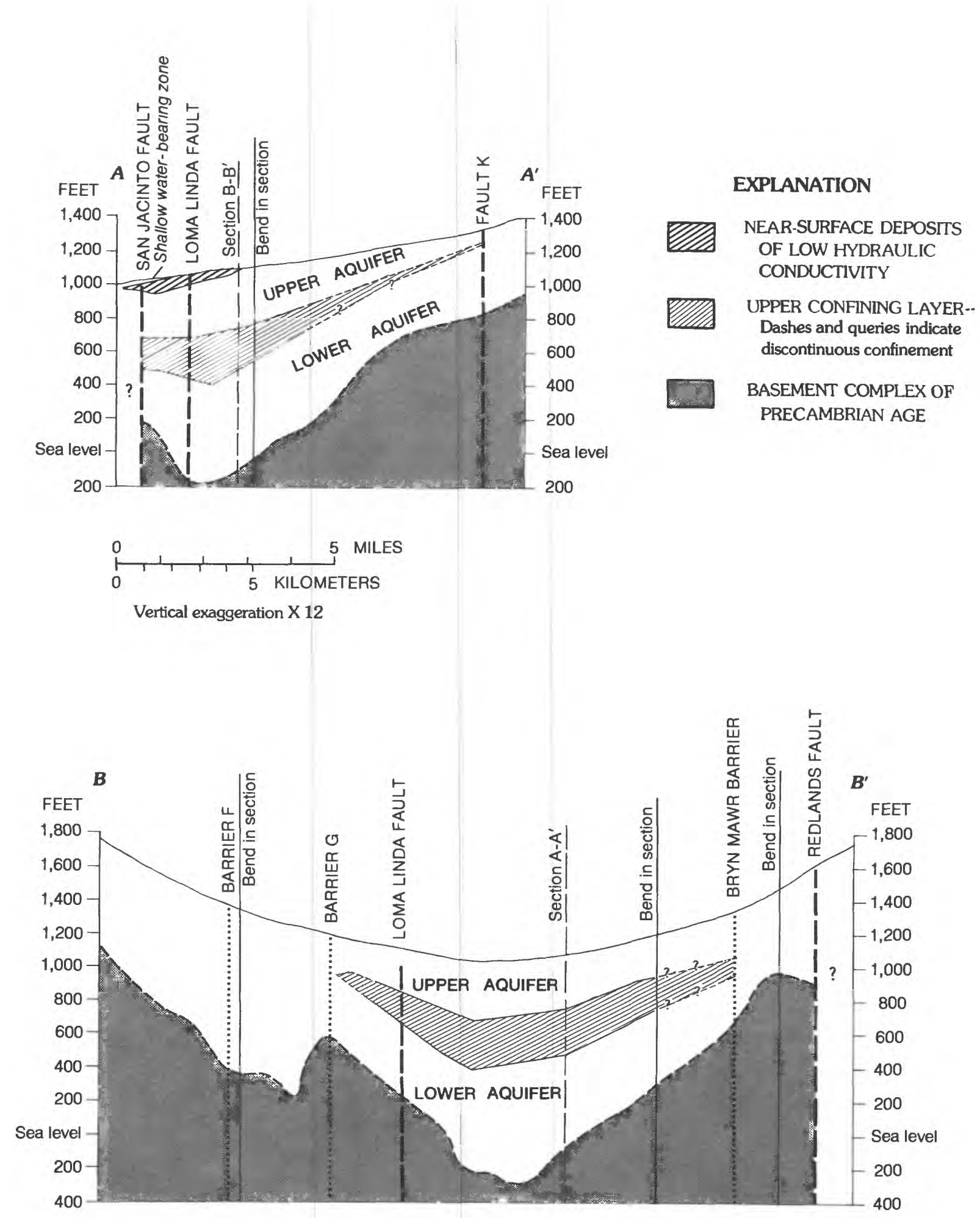

FIGURE 4.-- Geologic sections A-A' and B-B' (modified from Hardt and Hutchinson, 1980). See figure 3 for location of sections. 
Recharge to the Bunker Hill basin historically has resulted from infiltration of streamflow runoff from the San Gabriel and San Bernardino Mountains. During the period 1945-74, total measured stream inflow to the basin averaged about 143,000 acre-ft/yr, and measured stream outflow averaged about 35,000 acre-ft/yr (Hardt and Hutchinson, 1980, p. 24). Thus, the net stream inflow to the study area during this period was at least 108,000 acre-ft/yr. Three main tributary streams contribute more than 60 percent of the total recharge to the ground-water system. They are the Santa Ana River and Mill Creek in the southeast part of the basin, and Lytle Creek in the northwest part (fig. 2). Lesser contributors include Cajon Creek, Devil Canyon Creek, Waterman Canyon Creek, East Twin Creek, City Creek, Plunge Creek, and San Timoteo Creek. Artificial recharge during 1975-81 ranged from about 11,000 to 100,000 acre-ft/yr (Hardt and Freckleton, 1987, p. 19). Recharge from precipitation falling directly on the basin floor is assumed to be negligible because of the semiarid climatic conditions.

Ground-water levels in the Bunker Hill basin during the last 80 years initially declined and subsequently rose (Hardt and Freckleton, 1987, p. 11). In the early 1900 's, 'marshlands, springs, and flowing streams were evident in the swampland area (fig. 2). From the early 1940's to the late 1960's, ground-water levels declined more than 100 feet near San Bernardino in response to pumping for agricultural use and to below-normal precipitation. As a result, the former swampland dried completely and the land became urban as commercial and industrial development proceeded. Since the late 1960's, the basin has received greater than average quantities of recharge from increased streamflow caused by above-normal precipitation and by artificial recharge of local and imported water.

Depth to water was measured in selected wells of the Bunker Hill basin during April-June 1986. This information was used to estimate the altitude of the potentiometric surface for both the upper and lower aquifers, shown in composite form in figure 5. The potentiometric surface is the level to which ground water will rise in a tightly cased well. The direction of ground-water flow within the basin generally is similar to that of the surface drainage, which is toward the former swampland area. Surface water enters the unconfined aquifer through permeable deposits near the mountain fronts and along stream channels. Ground water generally moves toward the southwest--except in the Lytle and Cajon Creek areas, where it moves toward the southeast--and converges and discharges at the San Jacinto fault beneath the Santa Ana River. Present depth to water ranges from about 200 feet below land surface, in the east part of the basin near the Crafton Hills and Badlands area and north along the San Bernardino Mountains where Waterman Canyon and East Twin Creeks enter the basin, to near land surface, in the former swampland (fig. 2). 


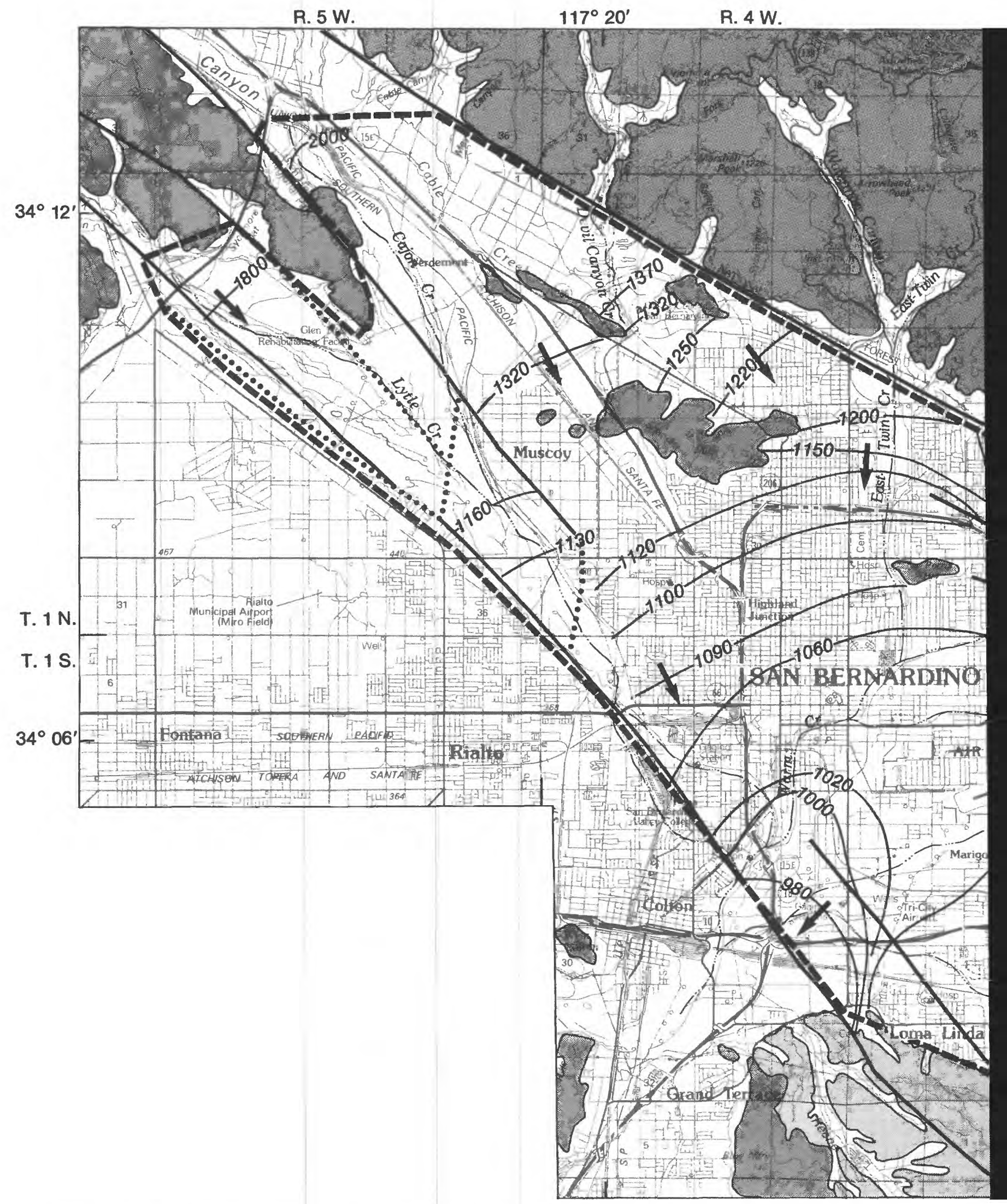

FIGURE 5.--Altitude of potentiometric surface and direction of ground-water movement, summer 1986. 


\section{0}

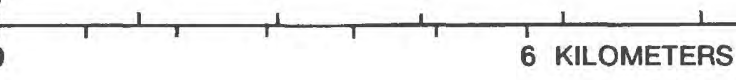

R 3 W

$117^{\circ} 10^{\prime}$
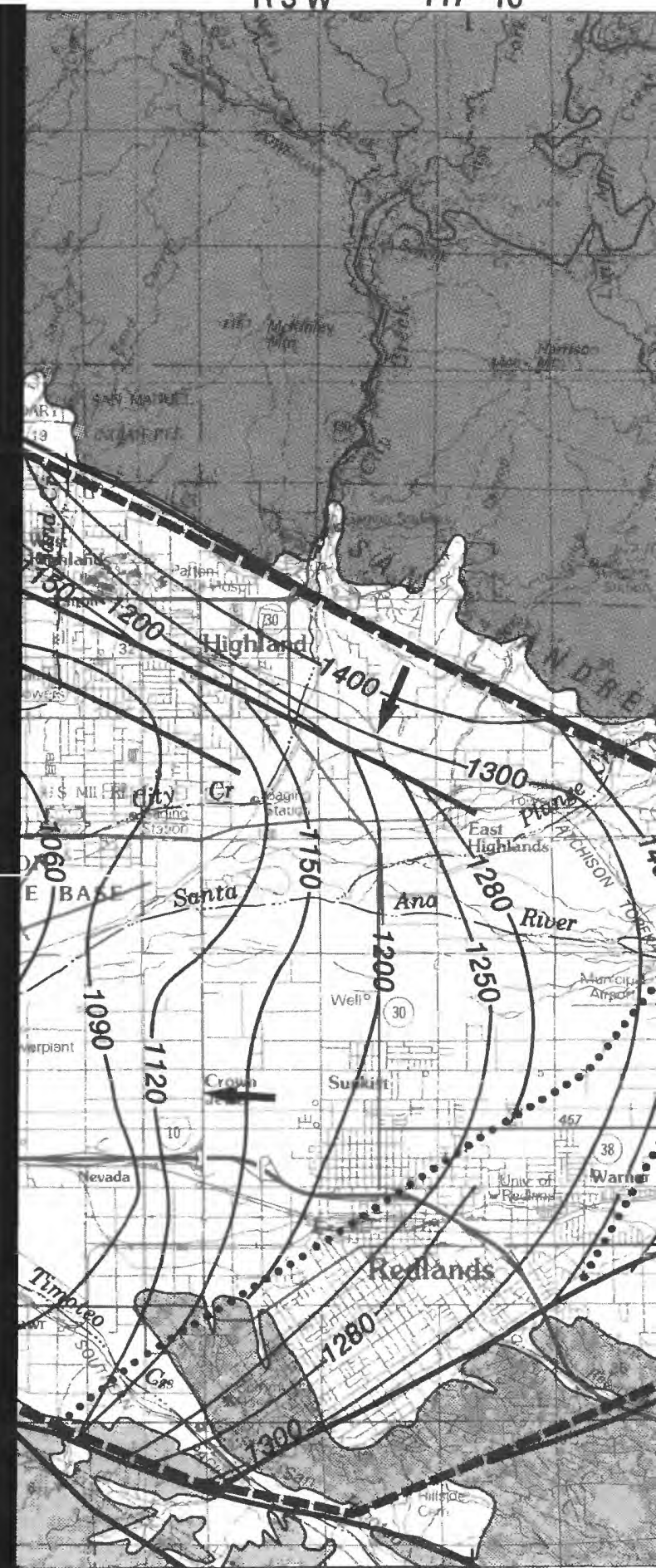

6 MILES

6 KILOMETERS

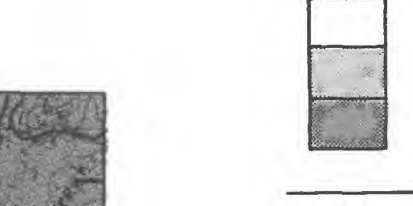

\section{EXPLANATION}

UNCONSOLIDATED DEPOSITS

PARTLY CONSOLIDATED DEPOSITS

CONSOLIDATED ROCKS

CONTACT

FAULT

- - - BOUNDARY OF STUDY AREA

.......... GROUND-WATER BARRIER

-1700- POTENTIOMETRIC CONTOUR-Shows composite altitude at which water level would have stood in tightly cased wells tapping both upper and lower aquifers. Contour interval variable, in feet. Datum is sea level

DIRECTION OF GROUND-WATER MOVEMENT

\section{R. 2 W.}

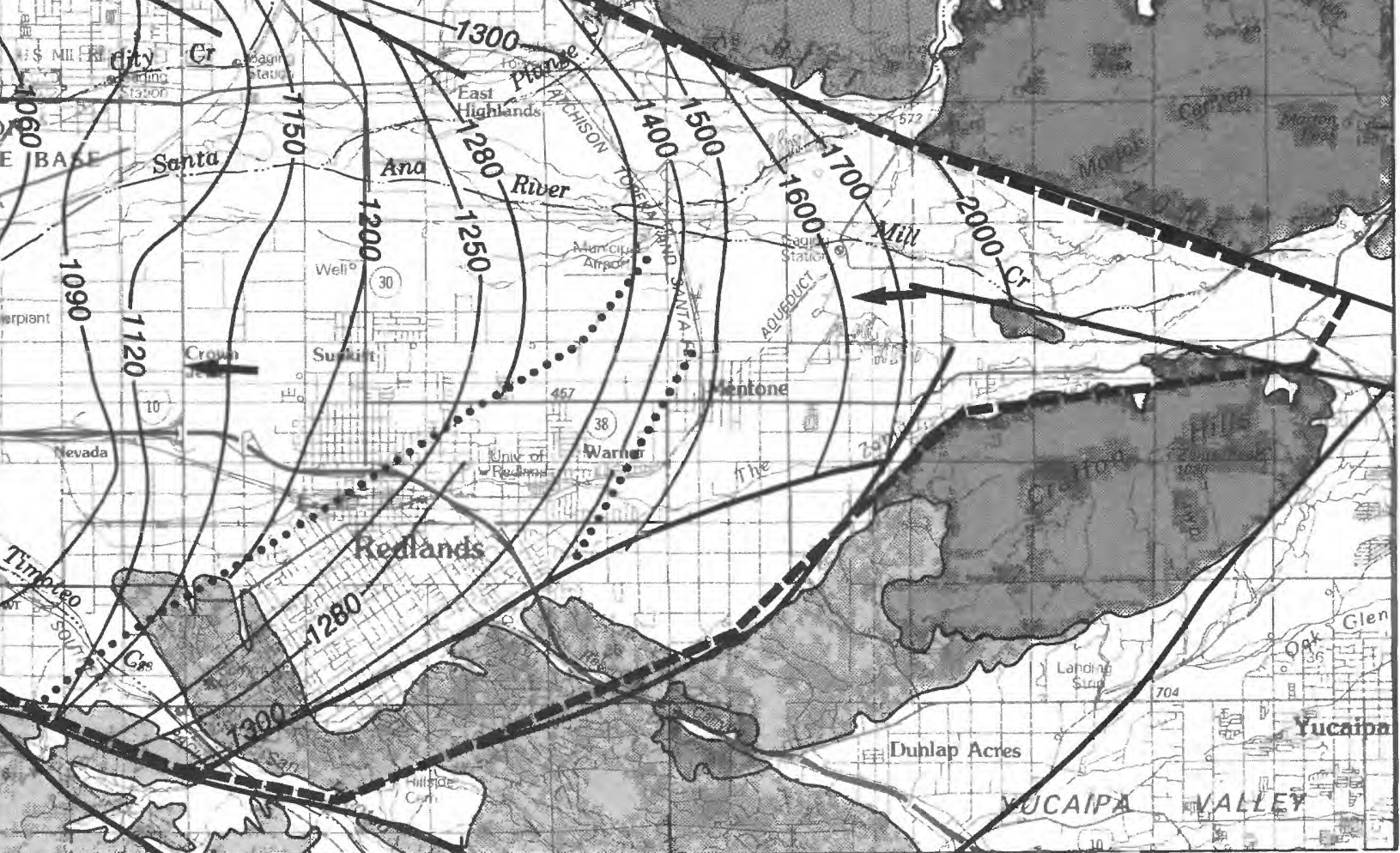

Geology modified from Dibblee $(1963,1968)$ and Dutcher and Garrett (1963) 
Human activities commonly are important factors affecting the contamination of ground water; the various land uses can determine the type of contaminants that might be present. Because previous, as well as current, land use may exert an influence on water quality, both recent and historical land-use information was used to classify land use in the vicinity of wells sampled for this study.

A survey in 1984 of the upper Santa Ana River drainage area by the California Department of Water Resources (1985) provided current land use on $1: 24,000$-scale U.S. Geological Survey topographic maps. Using this information, a land-use map for the Bunker Hill basin was prepared and is shown in figure 6. In preparing this map, small-scale details were ignored and several specific land-use categories were combined as shown below:

\begin{tabular}{l|l}
\hline $\begin{array}{c}\text { Land-use categories } \\
\text { (this study) }\end{array}$ & $\begin{array}{c}\text { Land-use categories } \\
\text { (California Department of } \\
\text { Water Resources, 1985) }\end{array}$ \\
\hline Urban & $\begin{array}{l}\text { 1) Residential } \\
\text { 2) Commercial }\end{array}$ \\
\hline Unused & 3) Industrial \\
& 4) Vacant, paved, or unpaved \\
& 5) Military \\
Citrus & 1) Native vegetation \\
Other agriculture & 2) Barren land \\
& 3) Stream channels \\
& 1) Orange and grapefruit \\
& 1) Field, vegetable, and grass crops \\
& 2) Avocados for \\
& 3) Feedlots for livestock or poultry \\
\hline
\end{tabular}


The most extensive land use in 1984 in the Bunker Hill basin was urban, which occupied approximately 50 percent of the area. Unused land occupied approximately 25 percent, citrus agriculture approximately 20 percent, and other agriculture approximately 5 percent of the basin. The major residential areas in the basin are in the cities of San Bernardino and Redlands. Approximate populations in 1986 were 150,000 for the city of San Bernardino, 50,000 for the city of Redlands, and 50,000 for the outlying parts of the basin. Large areas of unused land are located in the northwest and northeast parts of the basin. The major citrus-growing areas are in Loma Linda, in the southern part of the basin; in Redlands; and in East Highlands. Urban land use in the upper Santa Ana River basin increased approximately 23 percent between 1975 and 1984; acreage used for agricultural purposes decreased approximately 31 percent (California Department of Water Resources, 1985, p. 9). A similar pattern of changing land use has existed in the Bunker Hill basin.

Prior to 1950 , septic tanks were the primary method of sewage disposal in the Bunker Hill basin. Now virtually all the populated area is sewered. However, septic tanks still are used near Mentone in the eastern part of the basin and near Redlands. Currently (1986), six wastewater-discharge sites exist within the basin; three are sewage-discharge sites and three are industrial-discharge sites. One sewage percolation pond outside the northern part of the basin may discharge to the basin. Six former wastewater-discharge sites are no longer operated in the basin; three were sewage-discharge sites and three were industrial-discharge sites. The location of both active and inactive wastewater-discharge sites is shown in figure 6 . 


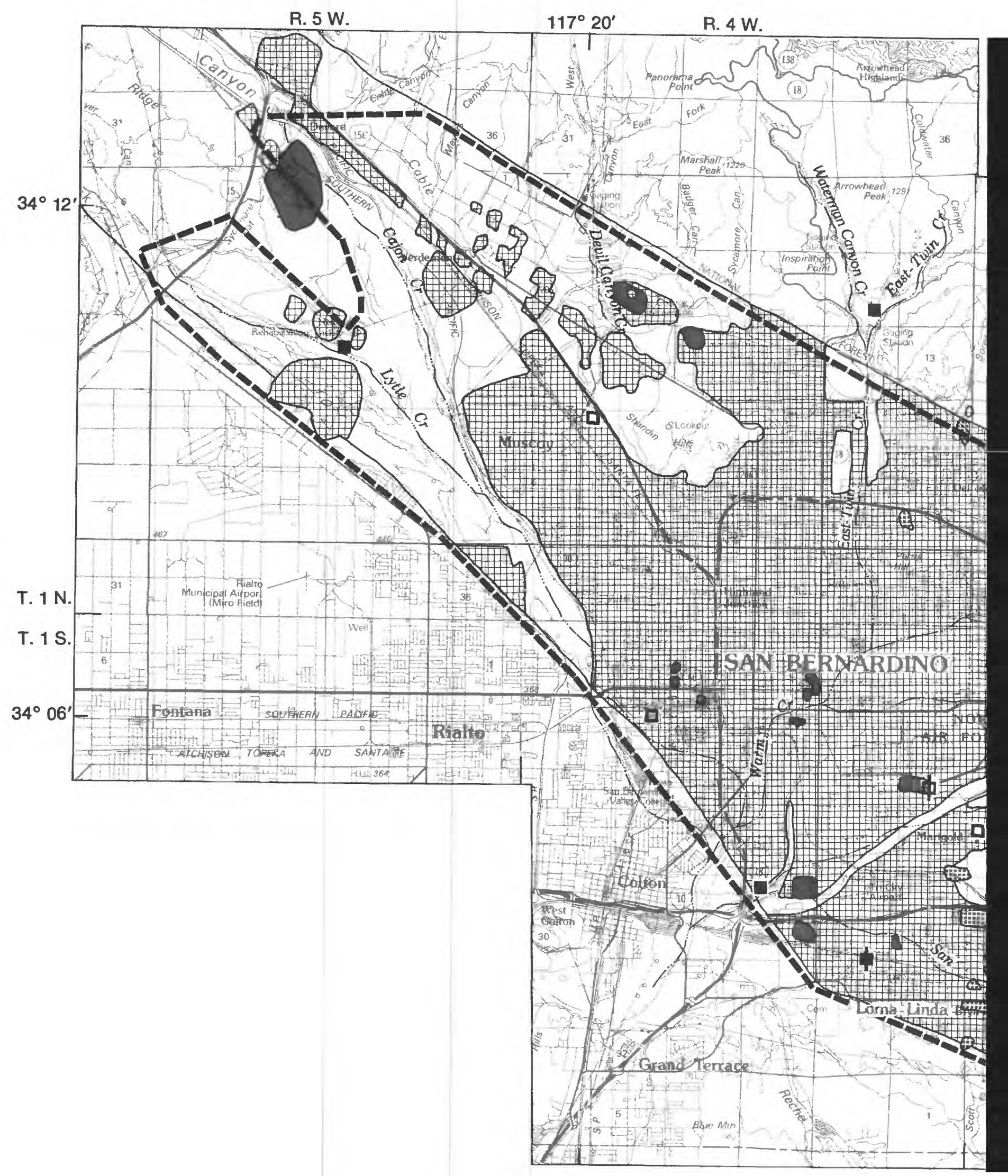

FIGURE 6.--Land use, 1984. 


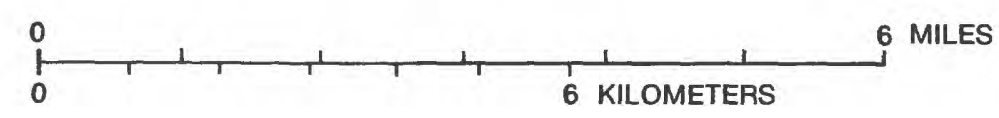

\section{EXPLANATION}

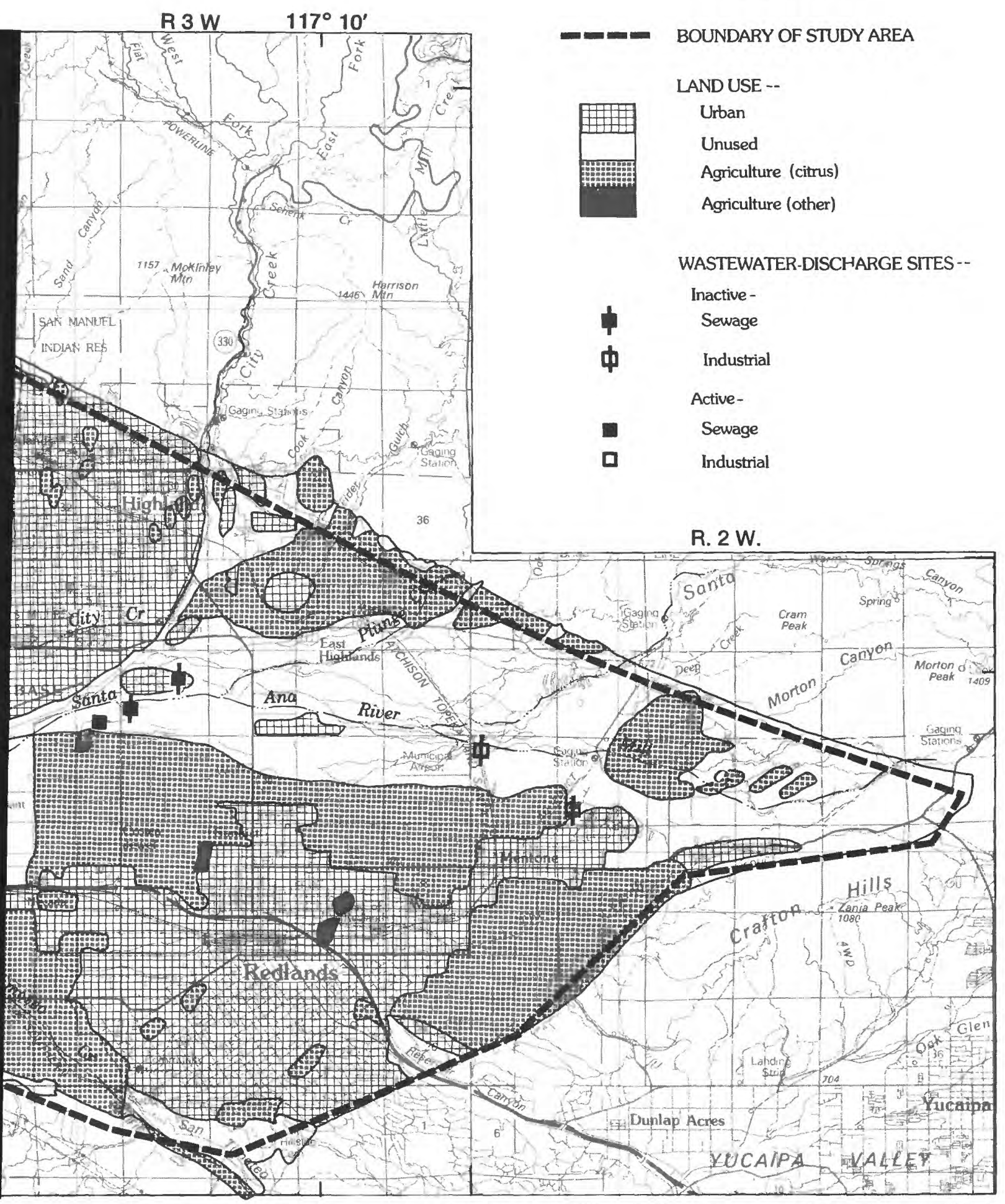

Land-use data modified from California Department of Water Resources (1985) 


\section{Site Selection}

Water-quality data were collected for this study from 47 agricultural, industrial, or municipal production wells (fig. 7). Physical data for the wells sampled are shown in table 1. Several criteria were considered important in the selection of wells. These include:

1. Information on well construction;

2. Perforation intervals contained entirely within a single aquifer;

3. The need to obtain adequate areal coverage in both aquifers;

4. Availability of historical water-quality data; and

5. Existence of wells within known contaminated areas, as well as upgradient and downgradient of suspected sources.

Data from wells sampled by other agencies were used where additional data were needed to define the areal distribution of dissolved solids and the extent of nitrate, PCE, and TCE contamination. Other agencies that currently collect or have collected ground-water-quality data in the Bunker Hill basin include the California Regional Water Quality Control Board (Santa Ana Region), California Department of Health Services, East Valley Water District, Patton State Hospital, Gage Canal Company, San Bernardino Valley Municipal Water District, and the cities of San Bernardino, Redlands, Loma Linda, Riverside, Rialto, and Colton.

Water samples were collected by the U.S. Geological Survey during AprilAugust 1986. Thirteen wells were resampled during that period to verify inorganic chemical, nitrogen, or volatile-organic-compound concentrations. The water-quality data from other agencies includes data collected since 1984. The historical water-quality data used in this study includes data obtained by the U.S. Geological Survey between 1955 and 1980 and stored in the WATSTORE computerized data-base system and data collected by other agencies between 1976 and 1978. 
Table 1.--Wells used for water-quality sampling

[USGS; U.S. Geological Survey. USGS well-identification number: First six digits are latitude, the next seven digits are longitude, and final two digits are sequence numbers to uniquely identify each site. Altitude of land surface is given in feet above sea level. Perforation interval and depth of well are given in feet below land surface. - -, no data available]

\begin{tabular}{|c|c|c|c|c|}
\hline $\begin{array}{c}\text { State we11 } \\
\text { No. }\end{array}$ & $\begin{array}{c}\text { USGS well- } \\
\text { identification } \\
\text { No. }\end{array}$ & $\begin{array}{l}\text { Altitude } \\
\text { of land } \\
\text { surface }\end{array}$ & $\begin{array}{l}\text { Perforation } \\
\text { interval }\end{array}$ & $\begin{array}{c}\text { Depth of } \\
\text { well, } \\
\text { total }\end{array}$ \\
\hline $001 N 003 W 27 N 02 S$ & 340819117111601 & 1,491 & $56-128$ & 150.00 \\
\hline 001N003W29M01s & 340830117133001 & 1,345 & $238-337,347-396$ & 408.00 \\
\hline 001N003W29N01S & 340814117132701 & 1,291 & $235-319,330-382$ & 409.00 \\
\hline 001N003W30J05S & 340830117133801 & 1,340 & $\begin{array}{l}3 \text { perforations } \\
\text { from } 485-798\end{array}$ & 820.00 \\
\hline $001 \mathrm{~N} 003 \mathrm{~W} 31 \mathrm{Q} 02 \mathrm{~S}$ & 340722117135801 & 1,120 & $\begin{array}{l}3 \text { perforations } \\
\text { from } 90-185\end{array}$ & 201.00 \\
\hline 001N004W08P01S & 341052117191801 & 1,477 & $186-351$ & 380.00 \\
\hline 001N004W16E01S & 341023117183901 & 1,412 & $186-406$ & 415.00 \\
\hline 001N004W16E04S & 341024117184501 & 1,413 & $300-404$ & 441.00 \\
\hline 001N004W25A01S & 340857117144601 & 1,296 & $\begin{array}{l}5 \text { perforations } \\
\text { from } 188-546\end{array}$ & 551.00 \\
\hline $001 \mathrm{~N} 004 \mathrm{~W} 25 \mathrm{C} 02 \mathrm{~S}$ & 340858117152002 & 1,246 & $378-569$ & 606.00 \\
\hline $001 N 004 W 26 E 02 S^{1}$ & 340846117160501 & 1,236 & $\begin{array}{l}3 \text { perforations } \\
\text { from } 320-660\end{array}$ & 689.00 \\
\hline 001N004W27G01s & 340846117171001 & 1,227 & $390-502$ & 502.00 \\
\hline 001N004W32D03S & 340757117193801 & 1,231 & $\begin{array}{l}7 \text { perforations } \\
\text { from } 150-658\end{array}$ & 685.00 \\
\hline 001N004W34G01S & 340746117170501 & 1,142 & $494-572,577-670$ & 700.00 \\
\hline 001S002W16F01S & 340515117053901 & 2,071 & $90-147$ & 160.00 \\
\hline 001S002W18R01S & 340442117074501 & 1,763 & $187-240,254-390$ & 401.00 \\
\hline 001S002W30B02S & 340334117073201 & 1,706 & $\begin{array}{l}5 \text { perforations } \\
\text { from } 120-228\end{array}$ & 250.00 \\
\hline 001S003W01H01S & 340649117082901 & 1,541 & $250-308,326-414$ & 414.00 \\
\hline 001S003W03R01S & 340632117102201 & 1,302 & $23-559$ & 575.00 \\
\hline 001S003W06H04S & 340659117133501 & 1,140 & $\begin{array}{l}3 \text { perforations } \\
\text { from } 173-415\end{array}$ & 421.00 \\
\hline 001S003W09E02S & 340605117122401 & 1,190 & $\begin{array}{l}3 \text { perforations } \\
\text { from } 211-385\end{array}$ & 401.00 \\
\hline 001S003W15G01S & 340509117105101 & 1,300 & $152-338$ & 354.00 \\
\hline 001S003W16A01S & 340518117112501 & 1,293 & $105-395$ & 418.00 \\
\hline $001 \mathrm{~s} 003 \mathrm{~W} 17 \mathrm{C} 03 \mathrm{~s}$ & 340527117130601 & 1,176 & $105-255$ & 296.00 \\
\hline 001S003W17H08S & 340506117123001 & 1,215 & -- & -- \\
\hline 001S003W17L01S & 340453117130101 & 1,189 & -- & 188.00 \\
\hline
\end{tabular}

See footnote at end of table. 
Table 1.--Wells used for water-quality sampling--Continued

\begin{tabular}{|c|c|c|c|c|}
\hline $\begin{array}{c}\text { State well } \\
\text { No. }\end{array}$ & $\begin{array}{c}\text { USGS well- } \\
\text { identification } \\
\text { No. }\end{array}$ & $\begin{array}{l}\text { Altitude } \\
\text { of land } \\
\text { surface }\end{array}$ & $\begin{array}{l}\text { Perforation } \\
\text { interval }\end{array}$ & $\begin{array}{l}\text { Depth of } \\
\text { well, } \\
\text { total }\end{array}$ \\
\hline 001S003W17R01S & 340442117123601 & 1,216 & -- & 360.00 \\
\hline $001 \mathrm{~S} 003 \mathrm{~W} 18 \mathrm{~N} 02 \mathrm{~S}$ & 340458117142801 & 1,107 & $793-988$ & 988.00 \\
\hline $001 S 003 W 21 E 02 S$ & 340413117122001 & 1,240 & $\begin{array}{l}4 \text { perforations } \\
\text { from } 88-250\end{array}$ & 264.00 \\
\hline 001s003W21H01s & 340422117113801 & 1,318 & -- & 426.00 \\
\hline 001S003W21H06s & 340414117113702 & 1,320 & $200-482$ & 500.00 \\
\hline 001S003W21H07s & 340424117112801 & 1,319 & $480-700$ & 723.00 \\
\hline 001S003W23A01S & 340426117092401 & 1,490 & $250-520$ & 549.00 \\
\hline 001S003W28H01S & 340314117112801 & 1,308 & $150-442$ & 474.00 \\
\hline 001S003w35H04S & 340233117093301 & 1,580 & $456-645$ & 657.00 \\
\hline $001 \mathrm{~S} 004 \mathrm{~W} 02 \mathrm{~K} 02 \mathrm{~S}$ & 340646117155701 & 1,058 & $1,250-1,374$ & $1,408.00$ \\
\hline 001S004W11D02S & 340617117163601 & 1,034 & $888-951$ & 963.00 \\
\hline $001 \mathrm{~S} 004 \mathrm{~W} 12 \mathrm{~B} 04 \mathrm{~S}$ & 340615117145901 & 1,087 & $\ldots$ & 818.00 \\
\hline 001S004W13F02S & 340506117152201 & 1,059 & $\begin{array}{l}5 \text { perforations } \\
\text { from } 216-402\end{array}$ & 422.00 \\
\hline 001S004W13N01S & 340441117153501 & 1,045 & $122-299$ & 325.00 \\
\hline 001S004W15L03S & 340454117171101 & 995 & $304-770$ & 800.00 \\
\hline 001S004W22D03S & 340437117173801 & 980 & -- & 35.00 \\
\hline 001S004W22H02S & 340425117164401 & 1,002 & $1,008-1,088$ & $1,106.00$ \\
\hline 001s004W22H03s & 340421117164401 & 1,001 & $275-325,408-645$ & 861.00 \\
\hline $001 S 004 W 23 A 05 S$ & 340433117154801 & 1,043 & $518-575,636-700$ & 704.00 \\
\hline 001S004W23K02S & 340401117160101 & 1,041 & $\begin{array}{l}4 \text { perforations } \\
\text { from } 84-279\end{array}$ & 303.00 \\
\hline 001S004W25B05S & 340343117150501 & 1,095 & $498-642$ & 682.00 \\
\hline
\end{tabular}

${ }^{1}$ The letter $\mathrm{E}$ in State well number $1 \mathrm{~N} / 4 \mathrm{~W}-26 \mathrm{E} 2$ was previously improperly assigned and cannot be corrected; the actual location of this well is in the $G$ 40-acre subdivision of section 26 of the same township and range.

\section{Field and Laboratory Methods}

Samples collected for this study were analyzed for dissolved inorganic chemicals, dissolved nitrogen and phosphorus, and volatile organic priority pollutants. The constituents analyzed are listed in table 2 . 
Table 2.--Water-quality constituents analyzed for this study

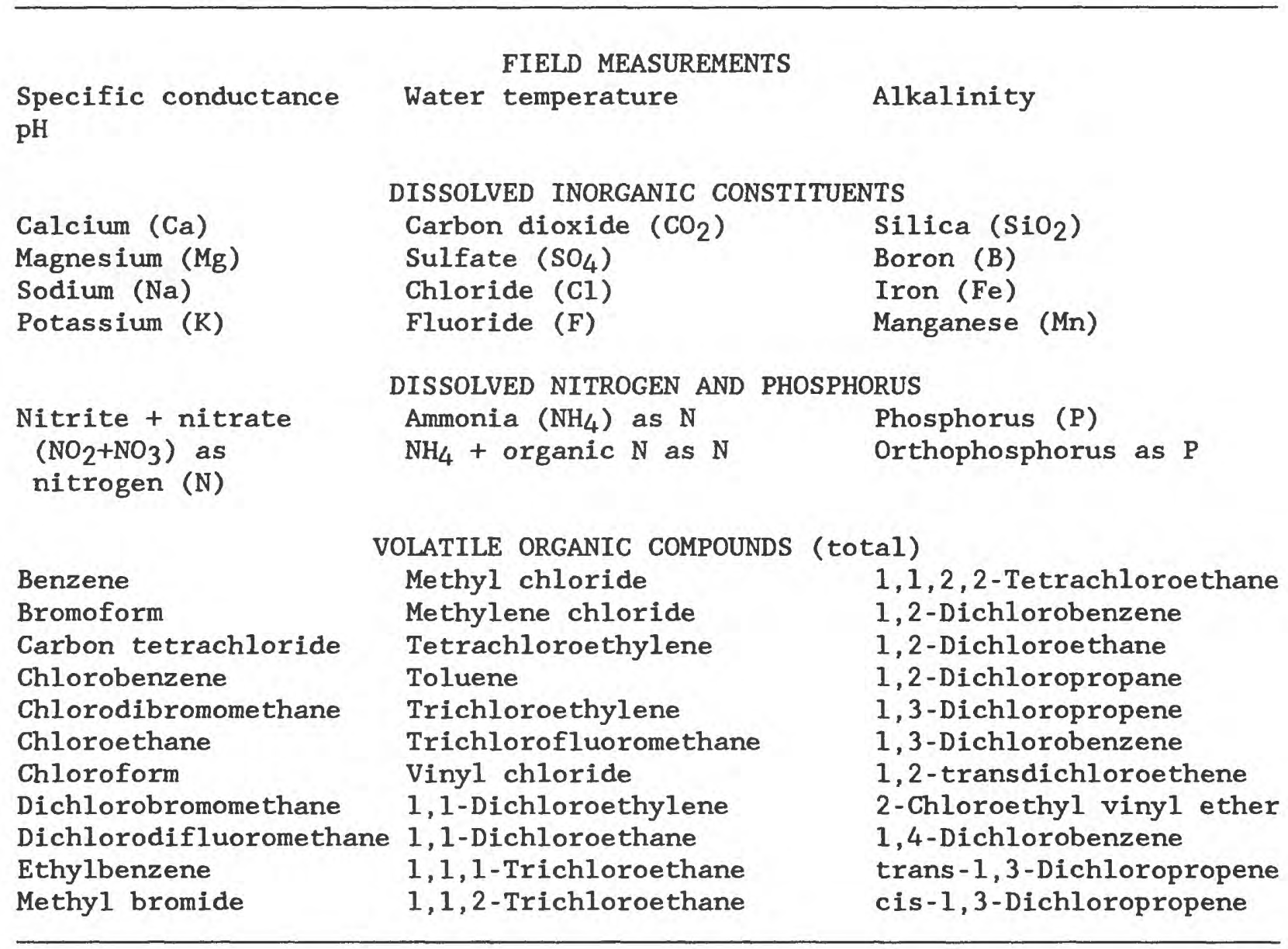

Specific conductance and $\mathrm{pH}$ were measured in the field using portable meters. Alkalinity also was determined in the field by titrating the water sample with $1.6 \mathrm{~N}^{1}$ sulfuric acid to an end point of $\mathrm{pH} 4.5$. Water-temperature measurements were made in the field with a hand-held mercury-filled thermometer having a full-scale precision of $0.5{ }^{\circ} \mathrm{C}$. Accuracy of the thermometer was assured by comparison to an American Society for Testing and Materials ${ }^{2}$ standard laboratory thermometer.

\footnotetext{
${ }^{1}$ The normality (N) of a solution is the number of gram-equivalent weights of solute per liter of solution.

${ }^{2}$ The use of firm and trade names in this report is for identification only and does not constitute endorsement by the U.S. Geological Survey.
} 


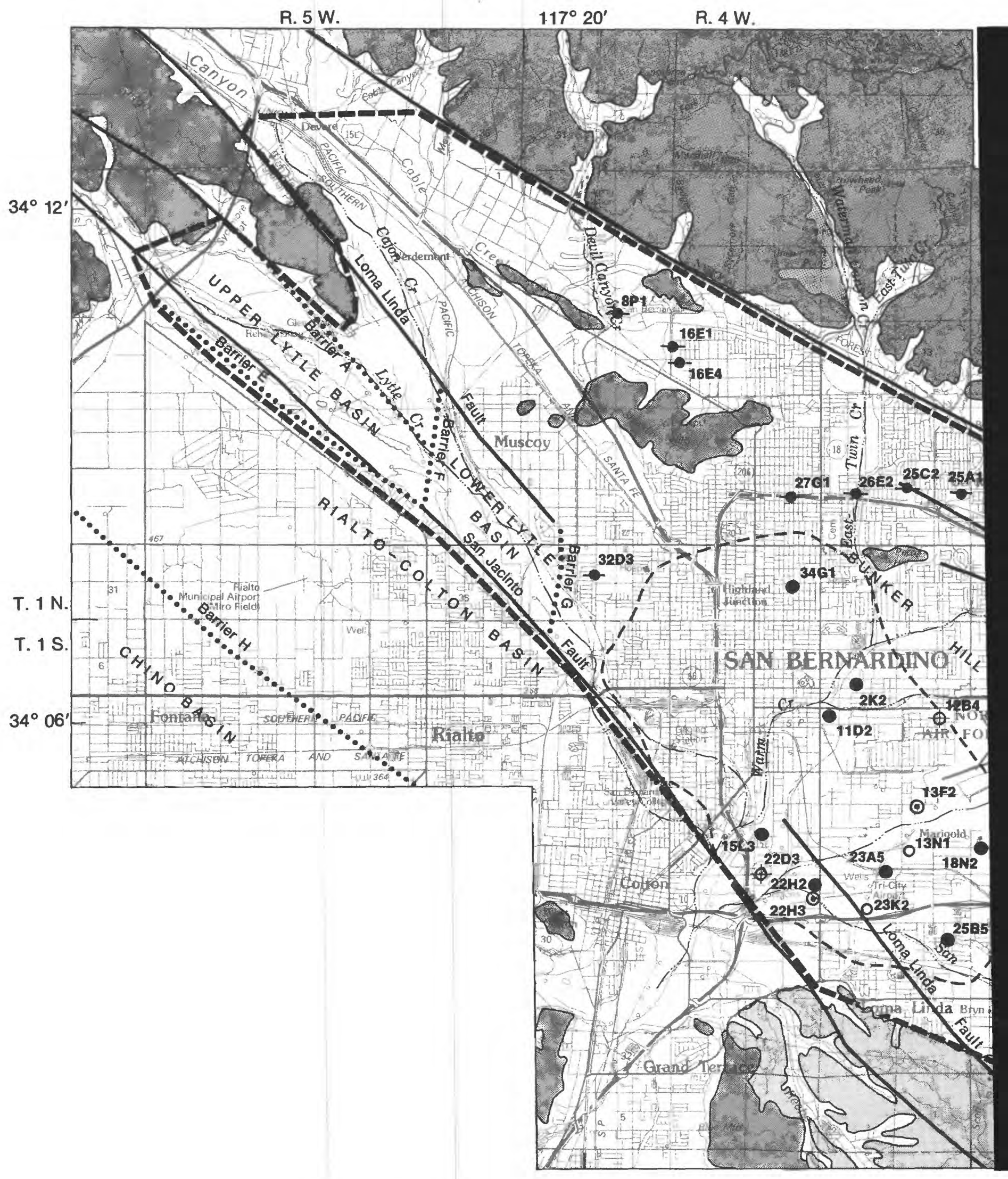

FIGURE 7.--Location of wells sampled. 


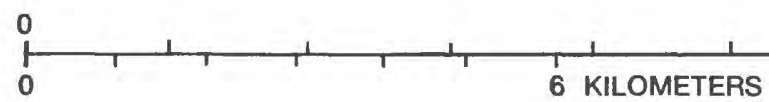

6 MILES
KILOMETERS

R3W $117^{\circ} 10^{\prime}$

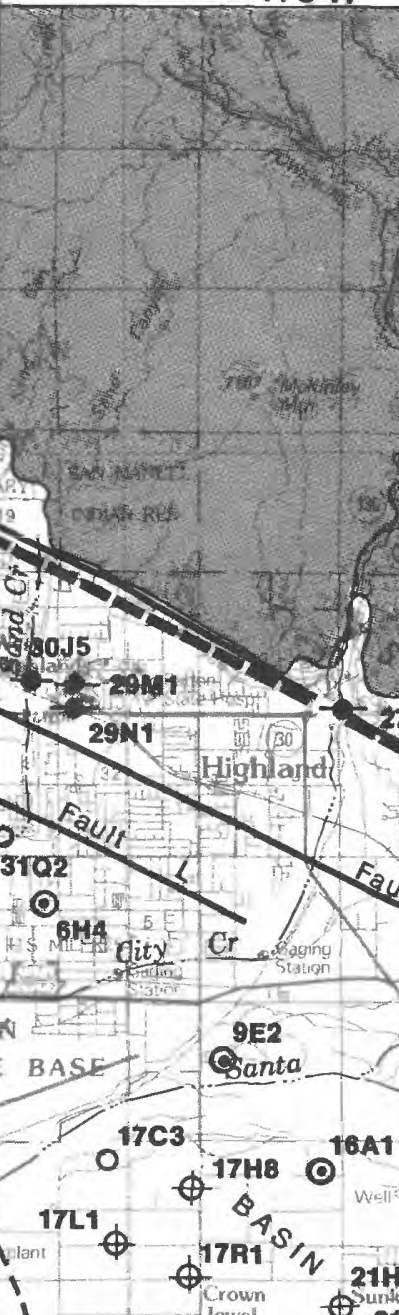

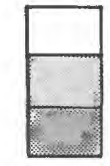
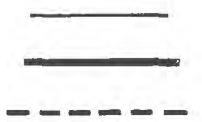

$0=$

-..........

$$
\begin{aligned}
& 0^{17 \mathrm{C} 3} \\
& 0^{18 \mathrm{~N} 2} \\
& 0^{15 \mathrm{G} 1}
\end{aligned}
$$
$\rightarrow 16 \mathrm{F1}$ $\phi^{21 \mathrm{H1}}$

\section{EXPLANATION}

UNCONSOLIDATED DEPOSTTS

PARTLY CONSOLIDATED DEPOSITS

CONSOLIDATED ROCKS

CONTACT

FAULT

BOUNDARY OF UPPER CONFINING LAYER

BOUNDARY OF STUDY AREA

GROUND-WATER BARRIER

WELL AND NUMBER

Upper aquifer

Lower aquifer

Upper and lower aquifers

With no confinement

Well perforation unknown

\section{R. $2 \mathrm{~W}$.}

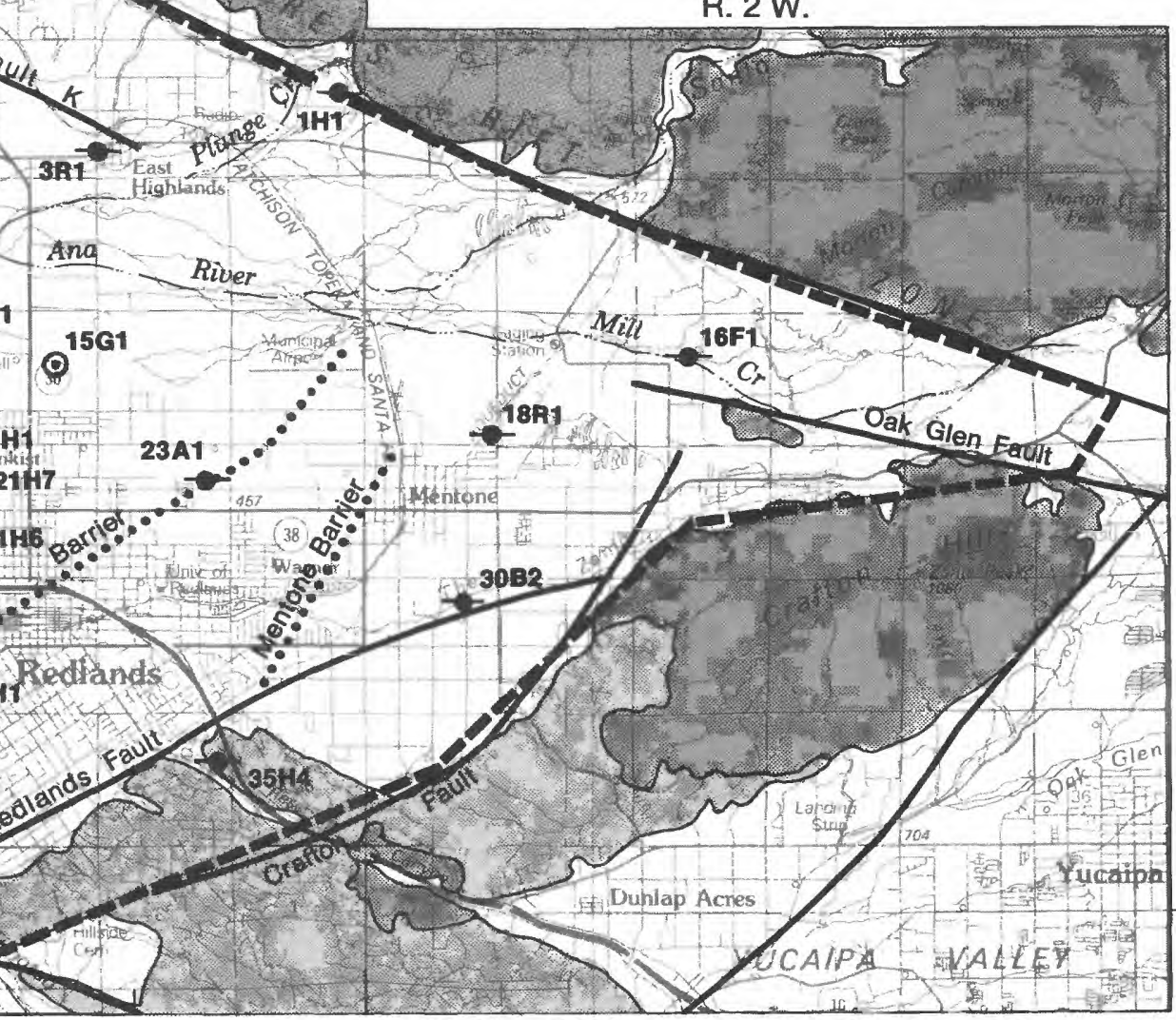

Geology modified from Dibblee $(1963,1968)$ and Dutcher and Garrett (1963) 
Flowing wells were sampled from small spigots at the well head. Before samples were collected from idle wells, at least 3 times the casing volume was pumped from the wells; samples were collected when water temperatures and specific conductance remained constant.

Samples analyzed for dissolved constituents were filtered in the field through a membrane filter having nominal pore openings of $0.45 \mu \mathrm{m}$. Cations were stabilized by acidification with nitric acid to a $\mathrm{pH}$ of less than 2 . Changes in nitrogen and phosphorous concentrations were minimized by the addition of mercuric chloride as a biocide, chilling at $4{ }^{\circ} \mathrm{C}$, and storage in an amber bottle to eliminate photosynthetic processes. Samples for analysis of volatile organic compounds were collected in 40 -mL glass vials with Teflonlined septum caps. Care was taken to avoid air bubbles in the filled vials. Before the vials were capped, a known volume of a solution containing three surrogate compounds (discussed in next section) was added.

Laboratory methods used by the U.S. Geological Survey for analysis of dissolved constituents are given in skougstad and others (1979). For historical data found in WATSTORE, laboratory analyses were done by the U.S. Geological Survey using methods given in Skougstad and others (1979) and Brown and others (1970). Analysis of volatile organic compounds was done using electron-impact gas chromatography/mass spectrometry. Detection limits were either 0.2 or $3.0 \mu \mathrm{g} / \mathrm{L}$, depending on the sensitivity requested. Chemical analyses for supplemental wells sampled by other agencies and included in this report were done by Clinical Laboratory of San Bernardino, Inc.; Edward $\mathrm{S}$. Bobcock and Sons, Inc.; and Montgomery Engineering, Inc. These laboratories were certified by the State of California at the time samples were analyzed.

\section{Quality Assurance}

Several quality-assurance procedures were used to ensure the validity of ground-water-quality data collected for this study. Duplicate samples were collected at one well for analysis of general inorganic chemicals and at three wells for analysis of organic compounds. Triplicate samples were collected at seven wells for analysis of nitrates. Six wells sampled for PCE and TCE by other agencies were sampled at the same time by the U.S. Geological Survey.

For analysis of volatile organic compounds, a "trip blank" consisting of distilled water from the laboratory was transported in the field and shipped to the laboratory in the same manner as samples from the wells. This procedure gives an indication of contamination from handling of samples in the field and in the laboratory. 
In addition, a small volume of a solution containing known concentrations of bromochloromethane, 1-bromo-2-chloroethane, and 1,4-dichlorobutane was injected with a hypodermic syringe into each sample before capping the vial in the field. These three compounds, which span the range in chemical characteristics of the volatile organic compounds analyzed, acted as "surrogates" and were used to compute percent recoveries. A fourth surrogate compound, 4-bromofluorobenzene, was added in the laboratory. Differences in the percent recovery between the surrogate added in the laboratory and the three surrogates added in the field can be used to evaluate the relative significance of losses incurred from handling in the field in comparison with losses incurred in the laboratory. As an internal standard, and to calibrate the instrument, fluorobenzene was added prior to analysis. All surrogates and the internal standard were added in amounts sufficient to produce a concentration of 20 $\mu \mathrm{g} / \mathrm{L}$ in the samples.

APPRAISAL OF GROUND-WATER QUALITY

Ground-water-quality data in the Bunker Hill basin are evaluated in this section by three methods:

1. Comparison with water-quality standards,

2. Correlation of relations between chemical composition and land-use patterns or perforated interval in wells, and

3. Determination of historical changes in chemical concentrations.

The California Department of Health Services has established specific water-quality standards, including maximum contaminant levels (MCLs), for domestic drinking waters. MCLs for constituents determined in this study are given in table 3 . These levels are the maximum permissible concentrations of contaminants in water that is delivered to a public water system. All groundwater-quality data collected for this study are given in the supplemental data section at the end of this report; these data indicate that MCLs (or "action levels") are exceeded in some wells for fluoride, nitrate, PCE, and (or) TCE. (An action level is the current recommended permissible level while the MCL is being determined.)

Helsel and Ragone (1984) discussed three statistical inference procedures that are useful in testing whether various factors can be correlated with differences in regional ground-water quality. These procedures use parametric analysis of variance, nonparametric methods for comparison of groups of data, and contingency-table analysis of frequency data. For this study, the nonparametric Kruskal-Wallis test and contingency table for frequency of detection were used, along with qualitative comparisons and graphical methods. Both statistical methods are described briefly below, and in greater detail in Conover (1980) and Helsel and Ragone (1984). 
Table 3.--Maximum contaminant levels for domestic drinking water

[Source: California Department of Health, 1977]

Constituent

Maximum contaminant level

Micrograms per liter

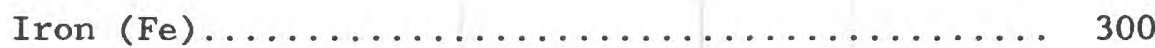

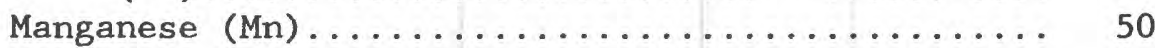

Tetrachloroethylene (PCE) ............... ${ }^{14}$

Trichloroethylene (TCE) ............... 15

Milligrams per liter

Chloride (C1)...................... ${ }^{2} 250-500$

Dissolved solids.................... ${ }^{2500-1,000}$

Fluoride (F) ................ ${ }^{3} 1.4-2.4$

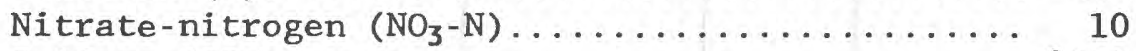

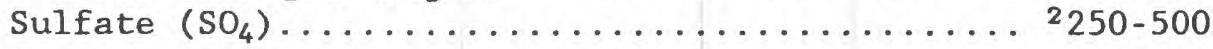

Microsiemens per

centimeter

at $25{ }^{\circ} \mathrm{C}$

Specific conductance................ 900-1,600

The Kruskal-Wallis test is analogous to a one-factor parametric analysis of variance (Conover, 1980). Concentration data are numerically ranked from lowest to highest for this test. The hypothesis that all subgroups of the ranked data produce (statistically) similar data then is tested against the alternative hypothesis that some subgroups produce dissimilar data. Confidence in the test is assigned a probability, or significance level $(\alpha)$, which also can be expressed as a percentage (100-100a). The $\alpha$ used for this study is 0.05 unless otherwise indicated. For this study, the data in table 4 for major-ion chemical composition, nitrate concentration, and dissolved-solids concentration were categorized into subgroups on the basis of predominant land use at the sampled well during 1984 and 1975-76 and of perforation intervals in the well casing (table 4). 


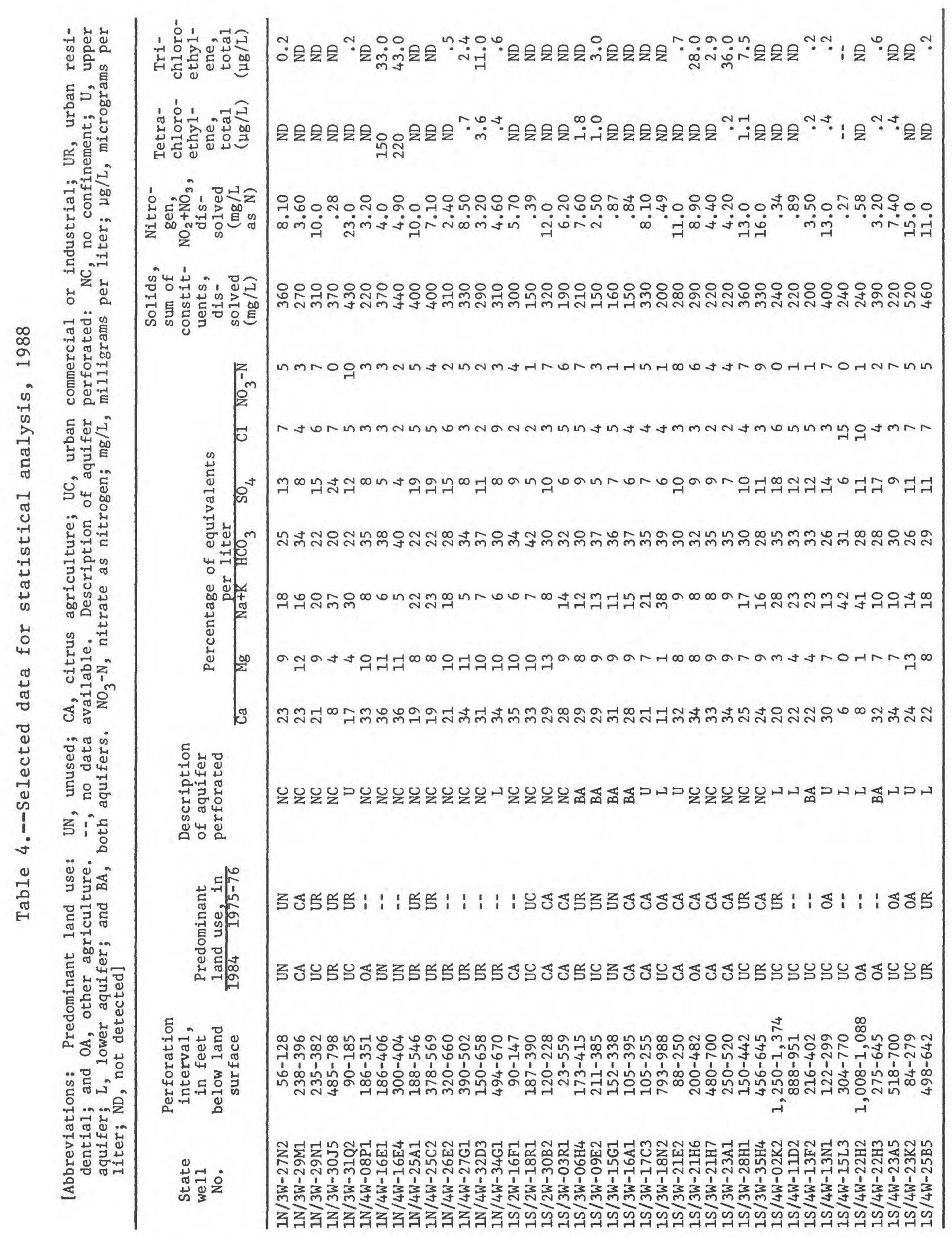


Helsel and Ragone (1984, p. 28) noted that rank-transform statistical tests, such as Kruskal-Wallis, should not be applied to data sets in which more than 20 percent of the values are less than the detection limit. Therefore, a categorical or nominal method that uses the frequency of exceeding the detection limit, rather than concentration itself, was used to evaluate volatile-organic-compound data in this study. Only PCE and TCE (table 4) were statistically tested with their concentration data segregated in two categories (detected or not detected) against subgroups based on land use and aquifer perforated (the same subgroups used in the Kruskal-Wallis test described above). These two compounds were selected from the list of 33 volatile organic priority pollutants in table 2 because they were among the more commonly found volatile organic compounds in this study and because the State of California has established "action levels," or recommended permissible concentrations, for these compounds while MCLs are being determined. In addition to the statistical test, all volatile-organic-compound data are summarized in tabular form giving frequency of detection and maximum concentration measured.

Data (collected by the U.S. Geological Survey) for 40 wells used for the statistical tests are in table 4. The monovalent alkali metals, sodium and potassium, are combined because potassium concentration usually is much lower than sodium concentration. Nitrate and dissolved-solids concentrations are in milligrams per liter, and PCE and TCE concentrations are in micrograms per liter. Only one set of concentrations was used for wells sampled more than once. Analyses from six wells sampled for this study were not included (data are given in the supplemental data section at the end of this report but are omitted from table 4) because their perforation intervals were not known. In addition, data from well $1 \mathrm{~S} / 3 \mathrm{~W}-1 \mathrm{H} 1$ were not used because organic data were not available and, for the inorganic data, the total cation concentration was 14 percent less than the total anion concentration, indicating possible analytical error. Perforation intervals given in table 4 are for the top and bottom openings and do not include the more detailed subintervals given in table 1. Predominant land use within a radius of one-half mile around each well was determined for 1984 from land-use maps furnished by the California Department of Water Resources and for 1975-76 from land-use maps in Eccles and Klein (1978) and Klein and Bradford (1979). The aquifer in which the well perforation interval is located was determined from geologic sections of Hardt and Hutchinson (1980).

\author{
Inorganic Chemistry \\ Inorganic-Constituent Concentrations
}

Methods of sampling and analysis for inorganic constituents were the same as those in routine use for many years; therefore, only a single "duplicate" (wel1 immediately resampled) sample was obtained--from well 1S/3W-18N2. Results, given in the supplemental data section at the end of this report, indicate that differences are no greater than a few percent for the major inorganic constituents. 
The inorganic quality of ground water in the Bunker Hill basin generally is suitable for most uses. In 46 wells sampled for this study, specific conductance and the concentrations of chloride, dissolved solids, and sulfate (supplemental data section) were found to be less than the higher (acceptable) MCLs shown in table 3. Concentrations of iron and manganese were less than the MCL in all wells except well 1S/4W-22D3, which is located in the former swampland (fig. 7). Although its perforated interval is not known, this well was drilled to a depth of approximately 35 feet and therefore does not penetrate the clay layer above the upper aquifer (San Bernardino Valley Municipal Water District, written commun., 1986). This well is used only periodically (mostly in the summer) for local dewatering of the shallow aquifer in the former swampland. The probable cause of high iron and manganese concentrations in the water from this well is the anoxic conditions in the shallow aquifer, or anoxic conditions in the well because of its infrequent use.

Ground water from five wells sampled for this study contained fluoride concentrations that exceeded the MCL for this area. MCLs for fluoride are based on the annual average of maximum daily air temperature. For the study area, the annual average of maximum daily air temperature is about $27{ }^{\circ} \mathrm{C}$; therefore, the MCL for fluoride is $1.4 \mathrm{mg} / \mathrm{L}$. Samples that exceeded this level (see supplemental data section) were from wells that are deeper than 400 feet and located north of fault $K$ or near the San Jacinto fault. The high fluoride concentration in these wells may be associated with deeper water moving upward along the faults or barriers, as suggested by Eccles and Klein (1978, p. 21).

Surface water entering the basin shows differences in concentrations of dissolved inorganic chemicals that are a result of differences in the composition of the rocks in which each stream originates (Dutcher and Garrett, 1963). Chemical concentrations in ground water from the vicinity of the streams are, in turn, influenced by the chemical composition of the recharging surface water. Differences in chemical composition commonly are expressed in an abbreviated way by designating the principal cations and anions (on an equivalents basis). For example, a calcium sodium bicarbonate water type is one in which calcium is the most abundant cation, sodium is the second most abundant cation, and bicarbonate is the most abundant anion.

Cajon, Waterman Canyon, East Twin, and San Timoteo Creeks originate in continental deposits of Tertiary and Quaternary age, and water in these streams generally has a dissolved-solids concentration greater than $400 \mathrm{mg} / \mathrm{L}$ (Dutcher and Garrett, 1963, p. 92). Lytle Creek, City Creek, Plunge Creek, Mill Creek, and the Santa Ana River drain areas in which the principal exposed rocks are the basement complex of Precambrian age, and water in these streams generally has a dissolved-solids concentration less than $300 \mathrm{mg} / \mathrm{L}$ (Dutcher and Garrett, 1963, p. 93). Furthermore, they found that water in East Twin Creek and in Waterman Canyon Creek (which join near the study area boundary) is of a sodium sulfate type. Water from San Timoteo Creek on the south side of the basin and City Creek and Plunge Creek on the east side generally is of a calcium sodium bicarbonate type. Water from Cajon Creek, Lytle Creek, Mill Creek, and the Santa Ana River is of a calcium bicarbonate type. 
Dissolved-solids concentration in ground water (1984-86) from the upper aquifer (including areas of no confinement) and from the lower aquifer is shown in figure 8. Lowest concentrations in the basin are found near the Santa Ana River, and concentrations generally increase in the direction (westward) of ground-water movement. Highest dissolved-solids concentrations in ground water are in the areas of Waterman Canyon-East Twin Creeks and San Timoteo Creek; concentrations generally decrease in the direction of ground-water movement as the water mixes with ground water that has been recharged along the Santa Ana River.

Differences in inorganic chemical composition of ground water from selected wells are illustrated with stiff diagrams in figure 9. For each wel1, concentrations (in milliequivalents per liter) of four cations were plotted, one on each horizontal axis to the left of a vertical zero axis; likewise, concentrations of three anions were plotted, one on each axis to the right of the zero axis. The resulting points were connected to give an irregular polygonal shape. The width of each diagram is an approximate indication of total ionic content.

Ground water from well $1 \mathrm{~N} / 4 \mathrm{~W}-25 \mathrm{C} 2$ is of a sodium calcium bicarbonate sulfate type, indicating the influence of recharge of sodium sulfate surface water from the Waterman Canyon-East Twin Creeks area and of mixing with calcium bicarbonate water from other areas. At well $1 \mathrm{~N} / 4 \mathrm{~W}-34 \mathrm{Gl}$, southwest and downgradient from wel1 $1 \mathrm{~N} / 4 \mathrm{~W}-25 \mathrm{C} 2$, the ground water is lower in dissolved solids and is of a calcium bicarbonate type, reflecting further dilution with calcium bicarbonate ground water that predominates in much of the basin (fig. 9).

Relation to Land Use and Aquifer

No effect of land use on the inorganic composition of ground water in the Bunker Hill basin could be discerned for 1984 or for 1975-76 using the Kruskal-Wallis statistical test. The test was applied by using the inorganicchemical data and the five subgroups of land use that are given in table 4. Because the effects of land use on ground-water chemistry presumably decline with increasing depth, the test also was applied to subsets of the data from which deeper wells had been removed. However, even when wells for which the top of the perforated interval is deeper than 300 feet (also deeper than 200 feet) below land surface were excluded, the test showed no difference in the inorganic chemistry of the ground water for the subgroups of land use.

No significant differences in chemical composition between the aquifers were found--except for nitrate, which is discussed in a later section. The absence of a statistically significant difference is caused in part by the rather wide range in chemical composition within each aquifer. Mean concentration and range in concentration of selected inorganic constituents in wells in the upper and lower aquifers are summarized in table 5. However, dissolved-solids concentrations were substantially higher in the upper than in the lower aquifer in the confined area (aquifers designated $U$ and $L$ in table 4). Wells penetrating both aquifers and wells outside the boundary of 
the upper confining layer (fig. 7) (we11s designated BA and NC in table 4) were not used in the statistical test. When well $1 \mathrm{~S} / 4 \mathrm{~W}-25 \mathrm{~B} 5$ in the lower aquifer is excluded from the test, the statistical significance increases from $\alpha=0.05$ to $\alpha=0.01$. The high dissolved-solids concentration in this well implies that its perforated interval (table 4) may be incorrect and that either the perforation interval actually extends into the upper aquifer or downward leakage around the we1l casing is occurring.

We11s $1 \mathrm{~N} / 4 \mathrm{~W}-34 \mathrm{Gl}, 1 \mathrm{~S} / 4 \mathrm{~W}-15 \mathrm{~L} 3,1 \mathrm{~S} / 4 \mathrm{~W}-23 \mathrm{~A} 5$, and $1 \mathrm{~S} / 4 \mathrm{~W}-25 \mathrm{~B} 5$ are perforated entirely within what is referred to as the "middle aquifer" by Dutcher and Garrett (1963), and wells 1S/3W-18N2, 1S/4W-02K2, 1S/4W-11D2, and 1S/4W-22H2 are perforated entirely within Dutcher and Garrett's "lower aquifer." (See discussion on page 9 in the "Geohydrology" section of this report.) Statistical testing of these data (excluding well 1S/4W-25B5 for reasons given in the preceding paragraph) reveals no significant difference in the inorganic chemistry of the lower and middle aquifers. This result supports the combining of the middle and lower aquifers into a single aquifer as defined by Hardt and Hutchinson (1980) and as used in this study, although it must be noted that this conclusion is based on data from a small number of wells.

Table 5.--Concentration of selected inorganic constituents in samples from we1ls in the upper and lower aquifers, 1988

\begin{tabular}{|c|c|c|c|c|c|c|c|c|c|}
\hline \multirow{2}{*}{$\begin{array}{c}\text { Number } \\
\text { of samples }\end{array}$} & & \multicolumn{6}{|c|}{ Concentration, in percentage of total ion equivalents } & \multicolumn{2}{|c|}{$\begin{array}{c}\text { Concentration, } \\
\text { in milligrams } \\
\text { per liter }\end{array}$} \\
\hline & & Calcium & Magnesium & $\begin{array}{l}\text { Sodium + } \\
\text { potassium }\end{array}$ & $\begin{array}{l}\text { Bicar- } \\
\text { bonate }\end{array}$ & Sulfate & Chloride & $\begin{array}{l}\text { Nitrate } \\
\text { as } \mathrm{N}\end{array}$ & $\begin{array}{l}\text { Dissolved } \\
\text { solids }\end{array}$ \\
\hline \multirow{4}{*}{5} & & \multicolumn{8}{|c|}{ Wells completed in upper aquifer } \\
\hline & Mean & 25 & 8 & 17 & 28 & 11 & 4 & 14.0 & 392 \\
\hline & Range & $17-32$ & $4-13$ & $9-30$ & $22-35$ & $7-14$ & $3-7$ & $8.1-23.0$ & $280-520$ \\
\hline & & \multicolumn{8}{|c|}{ Wells completed in lower acuifer } \\
\hline \multirow[t]{2}{*}{8} & Mean & 20 & 4 & 26 & 32 & 10 & 7 & 3.2 & 266 \\
\hline & Range & $6-34$ & $0-10$ & $6-42$ & $28-39$ & $6-18$ & $3-15$ & $0.34-11.0$ & $200-460$ \\
\hline
\end{tabular}

\section{Historical Trends}

Eccles (1979, p. 15) found that dissolved-solids concentration decreased between 1968-69 and 1977-78 in ground water from the upper Santa Ana River basin. The decrease was attributed to increased artificial recharge and restrictions on wastewater discharge, changing water use, and above-normal rainfall since 1976. However, comparison of current (1986) to historical ground-water-chemical data given in the U.S. Geological Survey computer data base (WATSTORE) indicates that concentrations of dissolved inorganic chemicals have changed little in the Bunker Hill basin since 1960. Used to make this comparison were wells $1 \mathrm{~N} / 4 \mathrm{~W}-27 \mathrm{Gl}$ and $1 \mathrm{~N} / 4 \mathrm{~W}-32 \mathrm{D} 3$, which are upgradient of confining layers in the basin; wells $1 \mathrm{~S} / 4 \mathrm{~W}-2 \mathrm{~K} 2,1 \mathrm{~S} / 4 \mathrm{~W}-13 \mathrm{~F} 2$, and $1 \mathrm{~S} / 4 \mathrm{~W}-22 \mathrm{H} 2$, which are perforated in the lower aquifer; and we11s $1 \mathrm{~S} / 4 \mathrm{~W}-13 \mathrm{NI}$ and $1 \mathrm{~S} / 4 \mathrm{~W}-$ 23K2, which are perforated in the upper aquifer. 


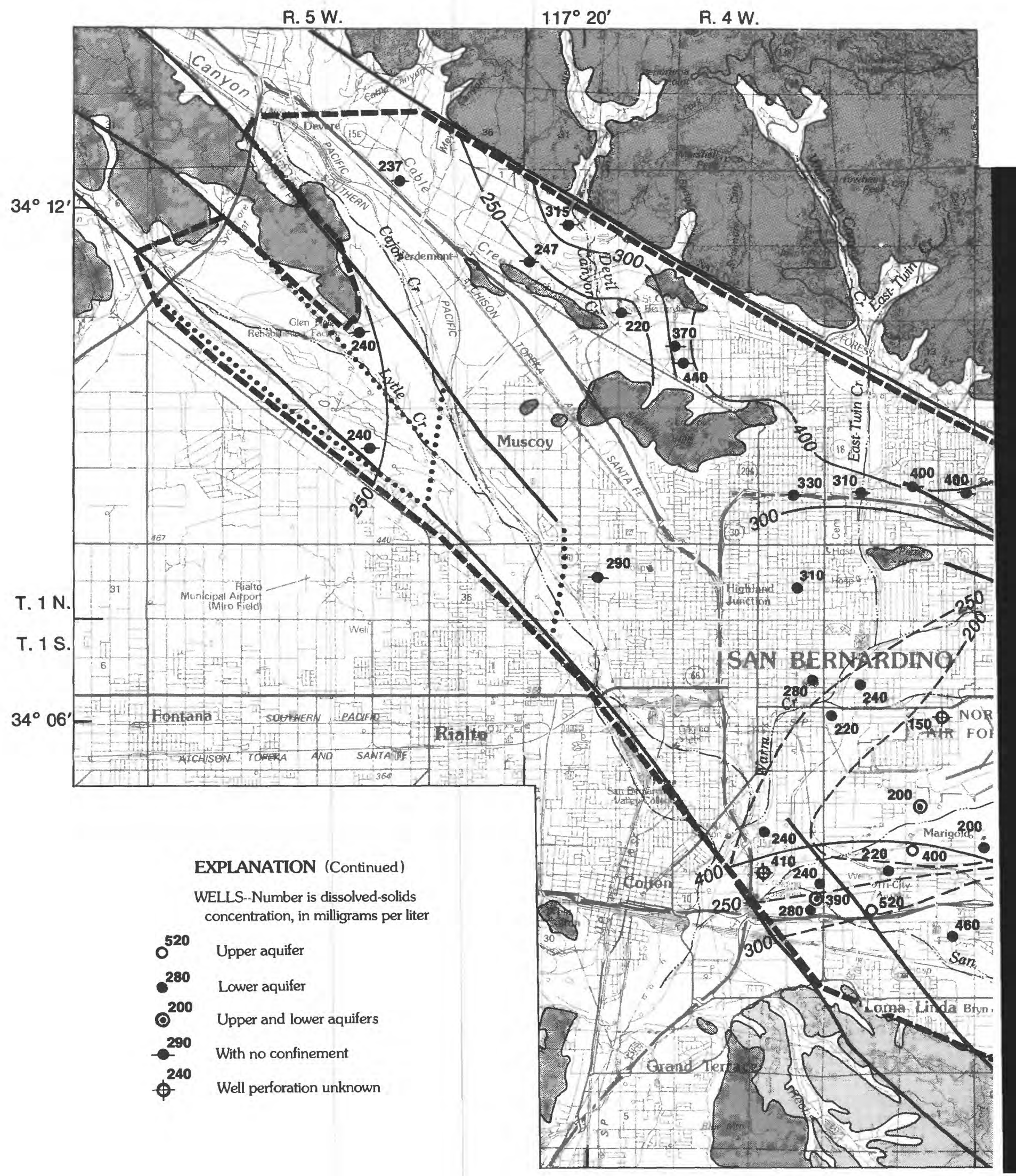

FIGURE 8.--Distribution of dissolved solids in ground water, 1984-86. 


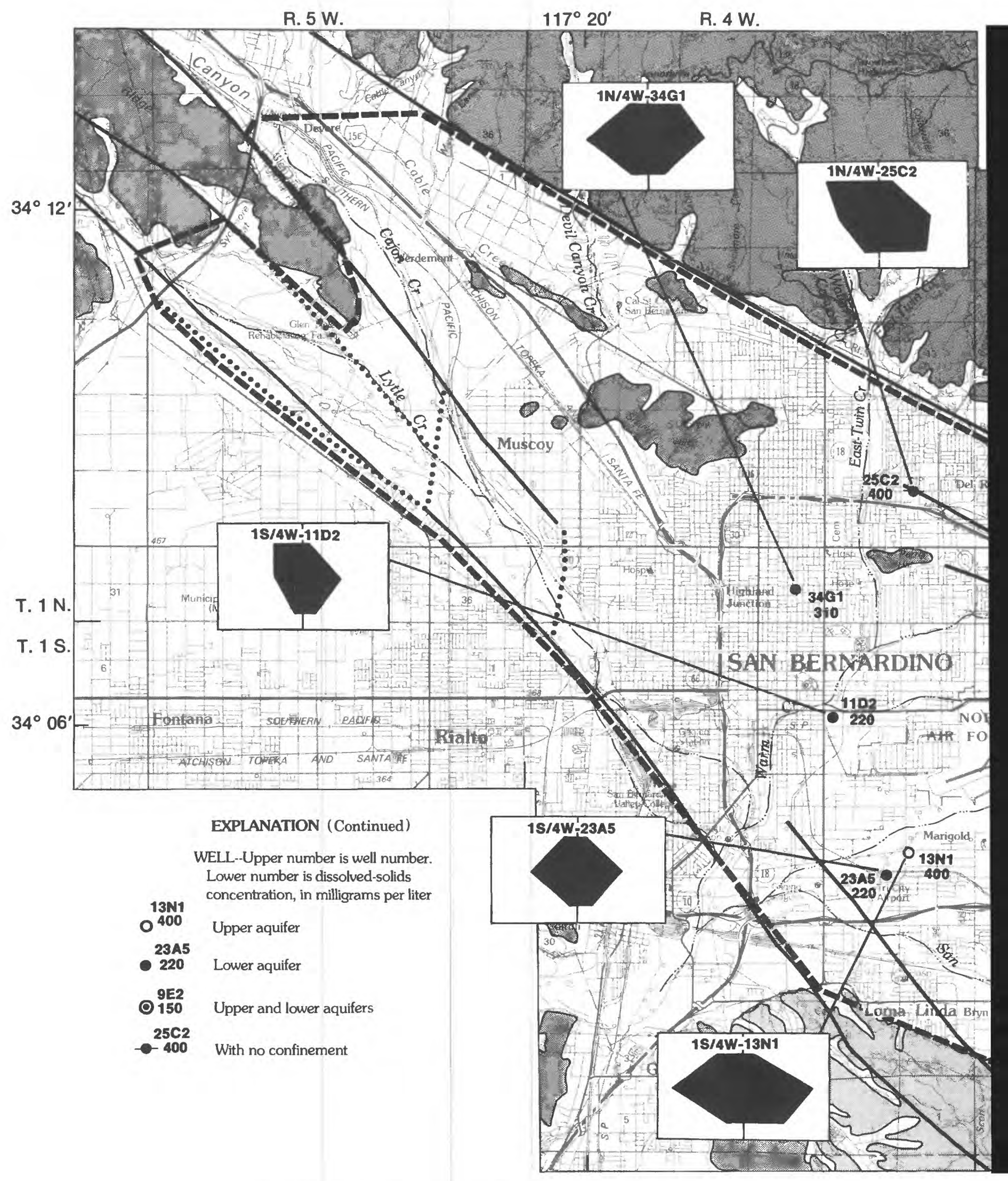

FIGURE 9.--Chemical quality of water from selected wells. 


\section{Nitrate}

Nitrogen exists in nature as several inorganic and organic forms, and transformations between these various forms are caused by a variety of biochemical processes. A brief discussion of these processes as they pertain to the study area is given by Klein and Bradford (1979). Because the current (1986) study found that by far the dominant form of nitrogen in ground water from the Bunker Hill basin is nitrate (supplemental data section at the end of this report), the following sections are limited almost entirely to the discussion of nitrate. Also, Klein and Bradford (1979, 1980) reported that nitrate was the predominant form of water-leachable inorganic nitrogen from the unsaturated zone in the parts of the basin studied by them. Furthermore, they showed that nitrite concentrations are low.

Nitrate concentrations were found to be virtually identical in three successively collected (triplicate) samples from seven wells (supplemental data section at the end of this report). Furthermore, little difference was observed for several wells sampled in spring 1986 and resampled in summer 1986. Nitrate concentrations in samples collected and analyzed by other agencies at the same time that samples were collected for this study also were in close agreement (difference less than 10 percent); therefore, data from other agencies are used in part of the discussion that follows. -

\section{Nitrate Concentration}

Nitrate concentration equaled or exceeded the MCL of $10 \mathrm{mg} / \mathrm{L}$ as $\mathrm{NO}_{3}-\mathrm{N}$ (nitrate as nitrogen) in 13 of 47 wells sampled for this study and in an additional 19 of 120 wells sampled by other agencies during 1984-86. Concentration of $\mathrm{NO}_{3}-\mathrm{N}$ ranged from 5 to $10 \mathrm{mg} / \mathrm{L}$ in 38 wells and was less than $5 \mathrm{mg} / \mathrm{L}$ in 97 wells. Nitrate concentrations in water from these 167 wells are shown in figure 10. Generally, highest concentrations were found in shallow wells in the Highland-East Highlands and Loma Linda-Redlands areas; both are areas of historical mixed-agricultural and citrus-agricultural land use that are becoming increasingly urban. Lowest concentrations generally were found in deep wells and in shallow wells recharged by low-nitrate water from the Santa Ana River.

\section{Relation to Land Use and Aquifer}

Eccles and Bradford (1977, p. 25) found that nitrate concentration in ground water from the Redlands area was dependent primarily on depth (perforated interval), with no clear relation to urbanization or agriculture. Klein and Bradford (1980, p. 40) found that nitrate concentrations in the shallow unsaturated zone in the Highland-East Highlands area were generally higher in or near present or historical agricultural areas (primarily citrus groves) and lower in historically uninhabited areas. However, a similar correlation was not demonstrated in the Redlands area (Klein and Bradford, 1979). 
Application of the Kruskal-Wallis statistical test to data from 40 wells sampled for this study (table 4), to 26 of the 40 wells with the top of the perforated interval within 300 feet of land surface, and to 19 of the 40 wells with the top of the perforated interval within 200 feet of land surface indicated no significant correlation between nitrate concentration and land-use categories given in table 4 for either 1984 or 1975-76. Although wells having $\mathrm{NO}_{3}-\mathrm{N}$ concentrations higher than $10 \mathrm{mg} / \mathrm{L}$ are located mainly in citrus-growing parts of the basin (compare concentrations in fig. 10 and land use in fig. 3), some shallow wells in the same areas also have low or moderate $(0.84-5.7 \mathrm{mg} / \mathrm{L}$ ) concentrations (for example, wells $1 \mathrm{~N} / 3 \mathrm{~W}-29 \mathrm{Ml}$, 1S/2W-16F1, 1S/3W-16Al, and $1 \mathrm{~S} / 3 \mathrm{~W}-23 \mathrm{Al}$ ). Therefore, a significant relation between high nitrate concentration and citrus agriculture cannot be demonstrated for data collected in this study.

The type and rate of biochemical reactions involving various species of nitrogen in the subsurface are dependent on the existence of significant numbers of suitable bacteria and on the organic matter, redox (anoxic or oxic) potential, $\mathrm{pH}$, moisture content, physical properties of the aquifer, and probably many other factors. Variations in these factors within the Bunker Hill basin may obscure any simple relation between nitrate concentration in ground water and current or historical land use.

Eccles and Bradford (1977) found that nitrate concentration in ground water from the Redlands area decreased with aquifer depth. They noted that exceptions to this general pattern could be caused by ground-water flow induced from shallow to deeper zones in the aquifer, by excessive drawdown in heavily pumped production wells, by pumping in adjacent wells with multiple perforated zones, and by "short-circuiting" around the casing in poorly sealed wells.

The graph in figure 11 illustrates the generally inverse relation shown in this study between nitrate concentration and depth interval of the well perforation. Nitrate as nitrogen concentrations (tables 4 and 5 ) in the upper aquifer ranged from $8.1 \mathrm{mg} / \mathrm{L}$ (we11 $1 \mathrm{~S} / 3 \mathrm{~W}-17 \mathrm{C} 3$ ) to $23.0 \mathrm{mg} / \mathrm{L}$ (we11 1N/3W-31Q2), whereas concentrations in the lower aquifer generally were less than $5 \mathrm{mg} / \mathrm{L}$, except from two we11s (1S/4W-25B5 and 1S/4W-23A5) in the Loma Linda area. Well $1 \mathrm{~S} / 3 \mathrm{~W}-35 \mathrm{H} 4$ in the Redlands area, with a perforation interval of 456-645 feet, was found to have $16.0 \mathrm{mg} / \mathrm{L}$ of $\mathrm{NO}_{3}-\mathrm{N}$. The Redlands and Loma Linda areas historically were used for citrus agriculture.

Application of the Kruskal-Wallis statistical test shows that nitrate concentration in ground water is significantly different in the four aquifer categories shown in table 4, and also is significantly different in the upper and lower aquifers in the central part of the basin where the lower aquifer is confined. Mean concentrations in the upper and lower aquifers in this area are calculated to be 14.0 and $3.2 \mathrm{mg} / \mathrm{L}$, respectively (table 5). 


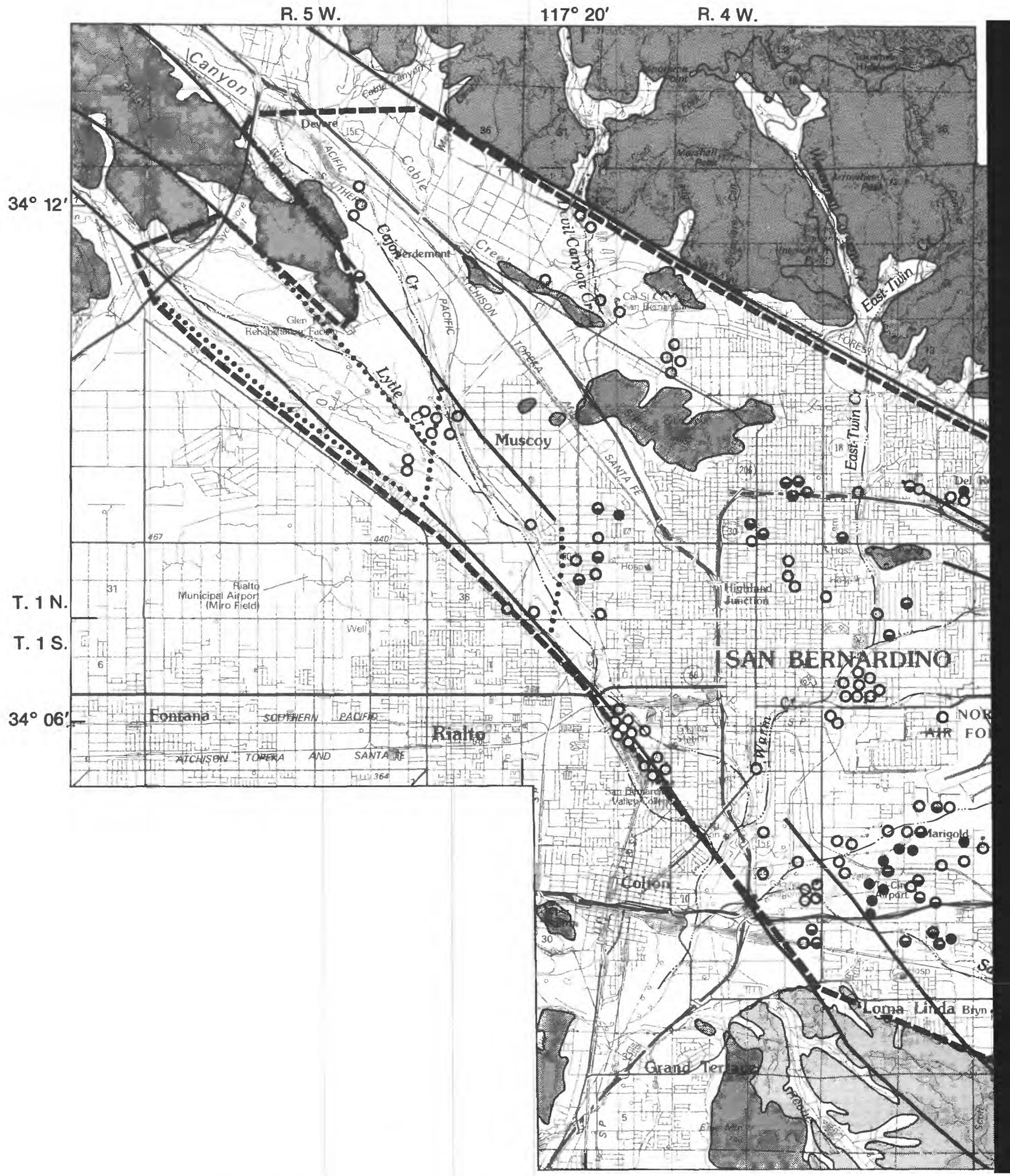

FIGURE 10.--Nitrate concentration in water from selected wells, 1984-86. 

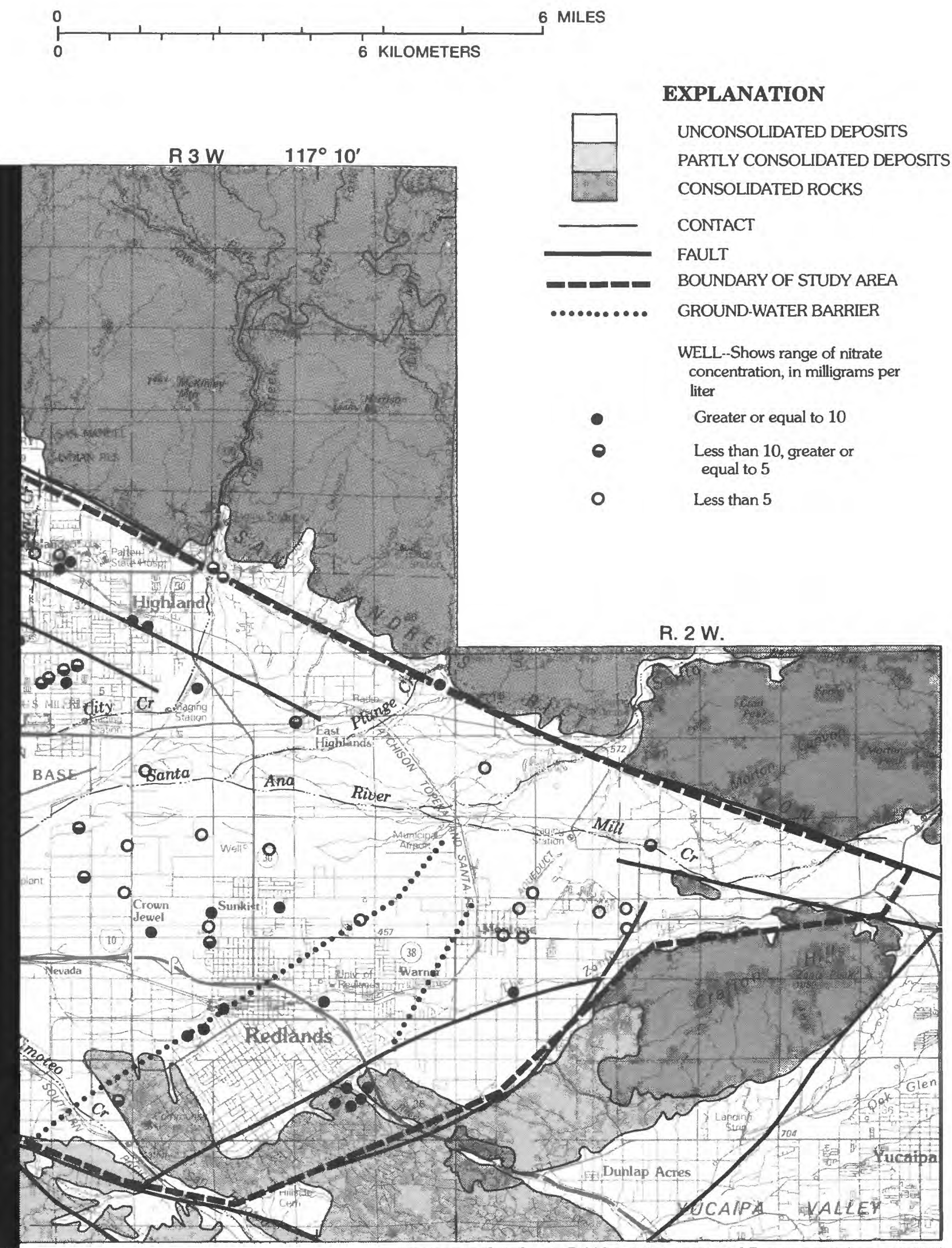

EXPLANATION

UNCONSOLIDATED DEPOSITS

PARTLY CONSOLIDATED DEPOSITS

CONSOLIDATED ROCKS

CONTACT

FAULT

WELL-Shows range of nitrate concentration, in milligrams per

Less than 10 , greater or equal to 5

R. 2 W.

Geology modified from Dibblee $(1963,1968)$ and Dutcher and Garrett $(1963)$ 


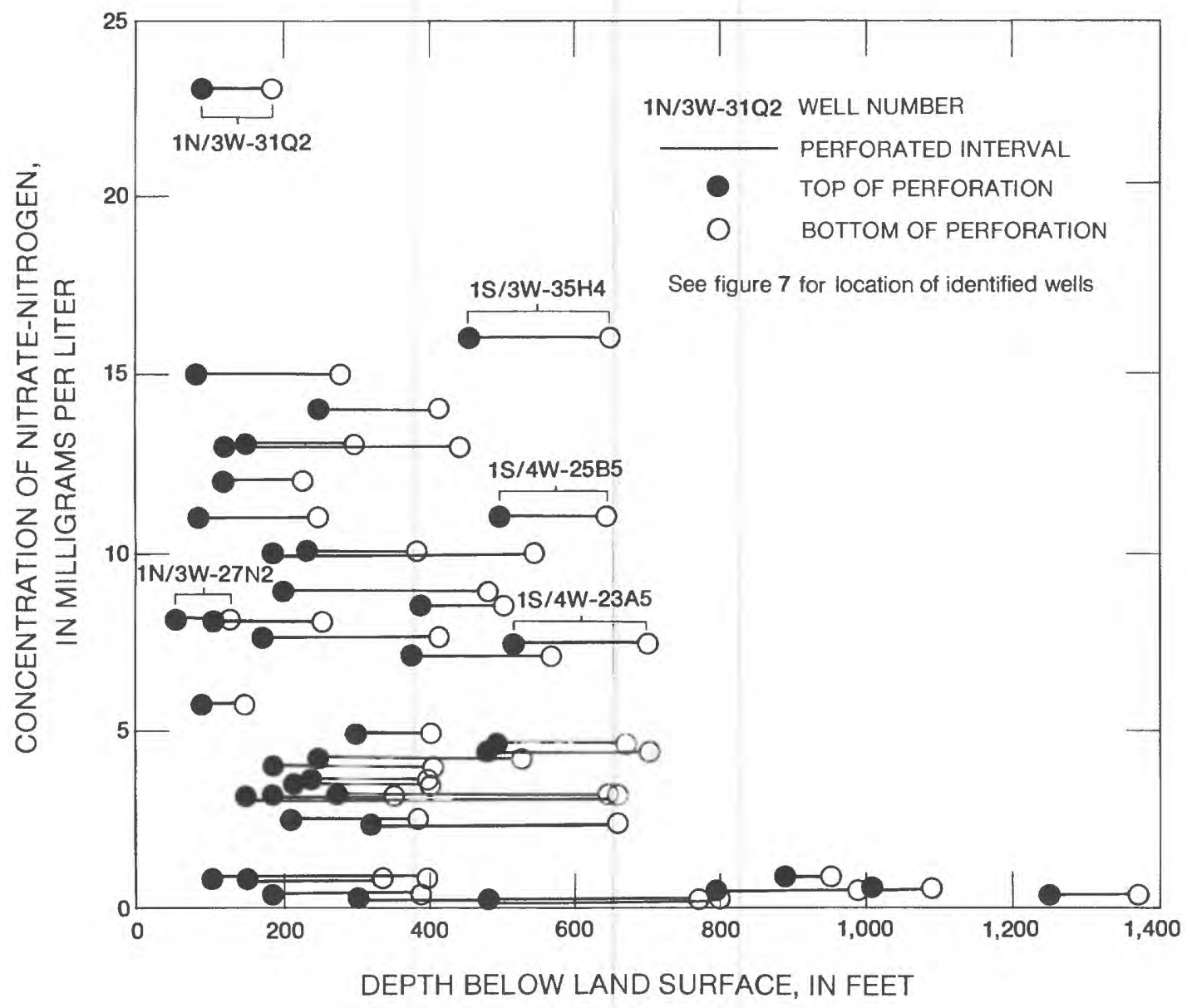

FIGURE 11.--Distribution of nitrate concentration compared to depth of well-perforation interval. 
A few analyses of ground water from the Redlands area show a much higher nitrate concentration in the 1970's than in the 1930's (Eccles and Bradford, 1977 , p. 13). Analyses from several wells in the same area also indicated an increase in nitrate concentration immediately after a period of heavy rain in 1968-69. Klein and Bradford (1979, 1980), following their finding of high nitrate concentration in the unsaturated zone in parts of the Bunker Hill basin, proposed a conceptual model in which a one-time rise in ground-water level with the water intercepting nitrate in the unsaturated zone could result in nitrate concentrations at the water table exceeding the MCL by severalfold. However, they noted that such high concentrations would be markedly reduced if there were significant vertical mixing and lateral transport. It would be desirable, given the limited information on which to base the choice of a realistic model, that periodic surveys such as this one be done to assess ground-water-quality conditions in the Bunker Hill basin.

Nitrate concentrations from as long ago as 1955 to the present (1986) for 17 wells are depicted graphically in figure 12. An areawide trend in concentration is not apparent. When earliest data are compared to the most recent data, nitrate concentrations are seen to have increased in seven wells, decreased in five wells, and remained about the same in five wells. In the central part of the basin where the lower aquifer is confined, nitrate concentration has increased in three wells perforated in the upper aquifer and decreased in one.

The $\mathrm{NO}_{3}-\mathrm{N}$ concentration in well $1 \mathrm{~S} / 3 \mathrm{~W}-17 \mathrm{C} 3$, just downgradient of the Redlands sewage-treatment plant that was abandoned in 1963, was reported to be $28 \mathrm{mg} / \mathrm{L}$ in the fall of 1974 (Eccles and Bradford, 1977, p. 21). The concentration in this well had decreased to $8.1 \mathrm{mg} / \mathrm{L}$ in spring 1986 (table 4).

\section{Volatile Organic Compounds}

The existence of ground-water contamination in the basin by volatile (purgeable) organic priority pollutants has been known for several years, although an assessment of changes with time is not possible because data were not collected prior to 1980. The URS Corporation (1986) found significant concentrations of PCE and TCE in soil-pore gas throughout the northwest part of the city of San Bernardino. Although unable to identify specific sources responsible for the contamination, URS listed businesses and activities in the area that are potential users of solvents containing PCE or TCE. As a result of ground-water contamination by PCE and TCE, pumping from 14 municipal water-supply wells in the area was discontinued as early as 1981. Pumping from five wells in the Redlands area was discontinued for the same reason.

Dibromochloropropane (DBCP), a soil fumigant whose use has been discontinued, also has been found in ground water from the Redlands area (California Department of Health Services and California Regional Water Quality Control Board, written commun., 1986). However, samples were not analyzed for DBCP in this study. 


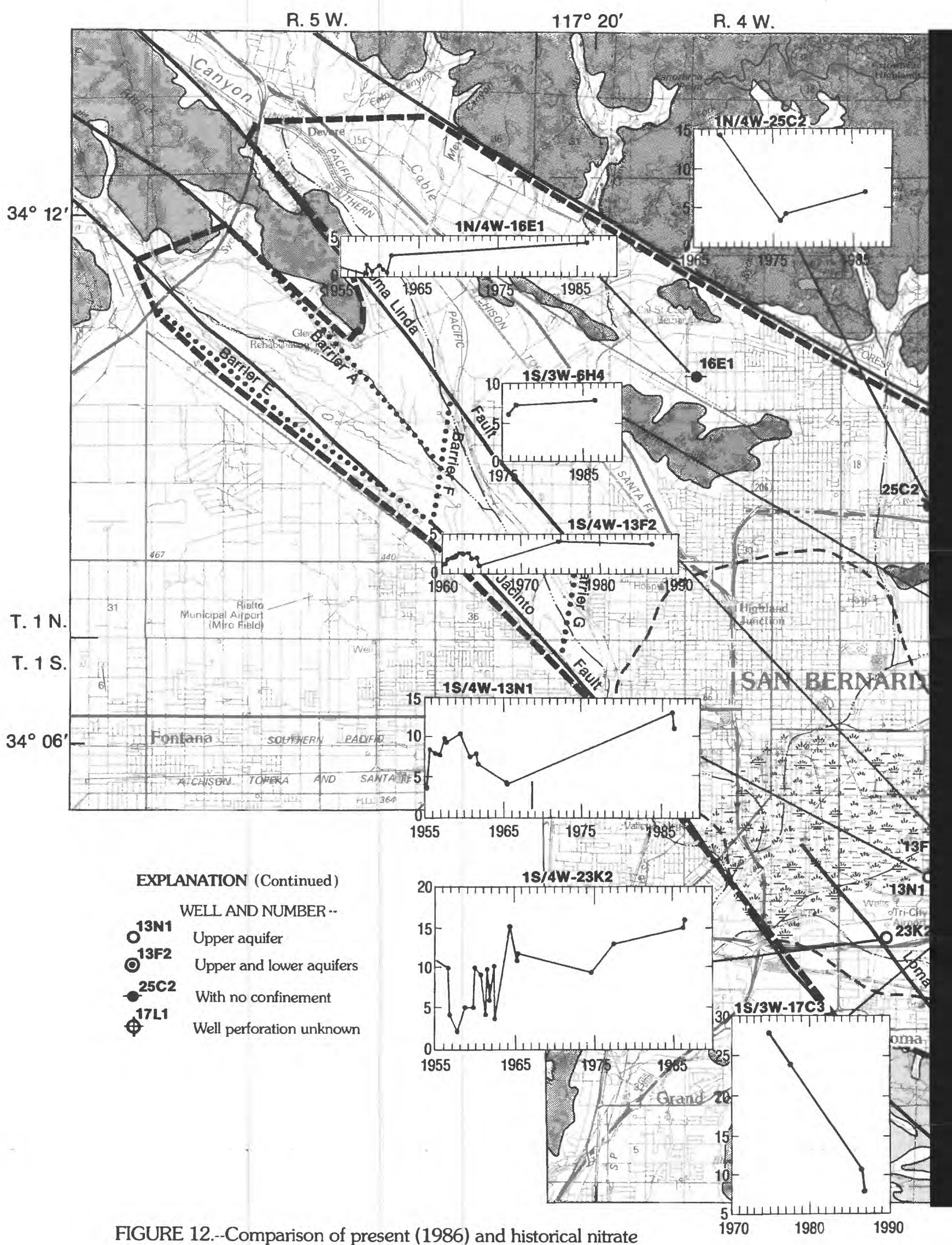
concentration in water from selected wells. 
A substantial quality-assurance program is an essential component of any investigation of volatile organic chemicals in ground water because of the complexity in sampling and analysis of these compounds at low concentrations. Quality assurance for this study consisted of the collection of duplicate samples, analysis of trip blanks, comparison with data from other agencies, and spiking of samples with surrogate compounds.

Calculated recoveries for the surrogate spikes are summarized in table 6 . Mean recoveries of the three surrogates added to the sample in the field were about 90 percent, indicating that very little loss occurred during sample collection and shipping. However, the rather wide range in recoveries, which is due partly to errors in precise addition of small quantities of the surrogate to the sample, illustrates the difficulties inherent in precise quantitation of organic concentrations. Results indicated that precision is 20 to 30 percent but that variations as large as twofold can be expected.

Table 6.--Summary statistics of recovery rate on surrogate spikes for 52 samples analyzed for volatile organic compounds

\begin{tabular}{lccc}
\hline $\begin{array}{c}\text { Surrogate } \\
\text { spike }\end{array}$ & $\begin{array}{c}\text { Range of recovery } \\
\text { rates (percent) }\end{array}$ & $\begin{array}{c}\text { Mean recovery } \\
\text { rate (percent) }\end{array}$ & $\begin{array}{c}\text { Standard deviation } \\
\text { (percent) }\end{array}$ \\
\hline & & & \\
Added in field & $39-148$ & 94 & 21.2 \\
\hline Bromochloromethane & $39-179$ & 91 & 25.5 \\
1-Bromo-2-chloroethane & $32-139$ & 89 & 30.4 \\
1,4-Dichlorobutane & & 104 & 12.6 \\
\hline
\end{tabular}

Results of analysis on duplicate ground-water samples from three wells are given in table 7 . Although results are qualitatively similar, comparison confirms the rather large variability expected from the range in recovery of surrogate compounds. PCE and TCE were found in two of the three wells, with their concentrations in the duplicates (where present) differing by multiples of 2 to 3 .

We1ls $1 \mathrm{~N} / 4 \mathrm{~W}-16 \mathrm{E} 1,1 \mathrm{~N} / 4 \mathrm{~W}-16 \mathrm{E} 4,1 \mathrm{~S} / 3 \mathrm{~W}-21 \mathrm{H} 1,1 \mathrm{~S} / 3 \mathrm{~W}-21 \mathrm{H} 6,1 \mathrm{~S} / 3 \mathrm{~W}-21 \mathrm{H} 7$, and 1S/3W-23Al were sampled and analyzed for PCE and TCE by other agencies at the same time that they were sampled and analyzed by the U.S. Geological Survey for this study. Although there were some differences in concentration values obtained, there was complete agreement in reported detection or nondetection for these six wells. 
Table 7.--Volatile-organic-compound concentrations in duplicate samples, 1988

[Concentrations are in micrograms per liter; <, actual value is less than shown; ND, not detected; --, no data available]

\begin{tabular}{|c|c|c|c|c|c|c|}
\hline $\begin{array}{r}\text { Compound } \\
\text { (total) }\end{array}$ & Well & $1 N / 4 W-16 E 4$ & Well & $1 S / 3 W-9 E 2$ & We11 & $1 \mathrm{~S} / 3 \mathrm{~W}-28 \mathrm{H} 1$ \\
\hline Benzene & ND & ND & ND & ND & ND & 0.6 \\
\hline Bromoform & ND & ND & ND & ND & ND & ND \\
\hline Carbon tetrachloride & ND & ND & ND & ND & ND & ND \\
\hline Chlorobenzene & ND & ND & ND & ND & ND & ND \\
\hline Chlorodibromomethane & ND & ND & ND & ND & ND & ND \\
\hline Chloroethane & ND & -- & ND & ND & ND & ND \\
\hline Chloroform & 4.6 & -- & ND & ND & 0.5 & 4.3 \\
\hline Dichlorobromomethane & ND & ND & ND & ND & ND & ND \\
\hline Dichlorodifluoromethane & ND & ND & 0.4 & 0.9 & .2 & .5 \\
\hline Ethylbenzene & ND & ND & ND & ND & ND & 1.9 \\
\hline Methyl bromide & ND & ND & ND & ND & ND & ND \\
\hline Methyl chloride & ND & ND & ND & ND & ND & ND \\
\hline Methylene chloride & 4.3 & 7.0 & $<1.0$ & $<2.0$ & ND & 100 \\
\hline Tetrachloroethylene & 220 & 600 & ND & ND & .4 & 1.1 \\
\hline Toluene & ND & ND & ND & ND & ND & 9.2 \\
\hline Trichloroethylene & 43.0 & 86.0 & ND & ND & 19.0 & 7.5 \\
\hline Trichlorofluoromethane & ND & ND & ND & ND & ND & 3.8 \\
\hline Vinyl chloride & ND & ND & ND & ND & ND & ND \\
\hline 1,1-Dichloroethylene & ND & -- & ND & ND & ND & .6 \\
\hline 1,1-Dichloroethane & 9.0 & 25 & ND & ND & ND & .4 \\
\hline 1,1,1-Trichloroethane & ND & -- & ND & ND & ND & .4 \\
\hline $1,1,2-\operatorname{Tr} 1$ chloroethane & ND & ND & ND & ND & ND & ND \\
\hline $1,1,2,2$-Tetrachloroethane & ND & ND & ND & ND & .5 & 2.0 \\
\hline 1,2-Dichlorobenzene & ND & -- & ND & ND & ND & ND \\
\hline 1,2-Dichloroethane & ND & ND & ND & ND & ND & ND \\
\hline 1,2-Dichloropropane & ND & -- & ND & ND & ND & ND \\
\hline 1,3-Dichloropropene & ND & ND & ND & ND & ND & ND \\
\hline 1,3-Dichlorobenzene & ND & -- & ND & ND & ND & ND \\
\hline 1,2-transdichloroethene & 35 & 22 & ND & ND & .4 & 2.9 \\
\hline 2-Chloroethyl vinyl ether & ND & ND & ND & ND & ND & ND \\
\hline 1,4-Dichlorobenzene & ND & -- & ND & ND & ND & ND \\
\hline trans-1,3-Dichloropropene & ND & ND & ND & ND & ND & ND \\
\hline cis-1,3-Dichloropropene & ND & ND & ND & ND & ND & ND \\
\hline
\end{tabular}


Analysis of five distilled-water trip blanks by the U.S. Geological Survey showed instances of concentrations higher than the detection limit of $0.2 \mu \mathrm{g} / \mathrm{L}$, but less than $2 \mu \mathrm{g} / \mathrm{L}$, for chloroform, dichlorodifluoromethane, methylene chloride, toluene, 1,1-dichloroethylene, 1,1,1-trichloroethane, 1,2-dichloroethane, and 1,2-dichloropropane. Methylene chloride was detected in four of the five trip blanks, but the other seven compounds were detected only once. These results show that low-level contamination is possible in the field, in transit, or in the laboratory. The high incidence of methylene chloride detection probably can be attributed to its widespread use in the laboratory, which leads to its absorption from the laboratory atmosphere.

\section{Volatile-Organic-Compound Concentrations}

Volatile-organic-compound concentrations in 57 samples from 45 wells are included in the supplemental data section at the end of this report. Frequency of detection and highest concentration for these compounds are summarized in table 8. Methylene chloride was the most frequently detected contaminant, but its actual presence in the ground water is questionable, for reasons noted in the preceding section. Its variable detection limit, which ranged from less than $1 \mu \mathrm{g} / \mathrm{L}$ to less than $30 \mu \mathrm{g} / \mathrm{L}$ as determined by the laboratory, is a consequence of day-to-day variations in the level of laboratory contamination. Twenty-three other volatile organic compounds were detected in at least one sample; PCE and TCE, detected in about half the samples, were among the more commonly detected contaminants.

Results of PCE analyses on water from 134 wells and TCE analyses on water from 138 wells are shown in figures 13 and 14 , respectively. The analyses were done during 1984-86. Eleven wells in the northwest part of the city of San Bernardino had PCE concentrations equal to or greater than the $4-\mu \mathrm{g} / \mathrm{L}$ action level designated by the State (fig. 13). Twenty-five additional wells throughout the basin had concentrations that exceed the detection limit for PCE but are less than the action level. Eleven wells in northwest San Bernardino and in central Redlands had TCE concentrations equal to or greater than the $5-\mu \mathrm{g} / \mathrm{L}$ action level (fig. 14). Thirty-eight additional wells throughout the basin had concentrations of TCE that exceed the detection limit. No particular pattern of contamination is apparent, other than in the northwest San Bernardino and central Redlands areas. 
Table 8.--Frequency of detection, highest concentration, and well having the highest concentration of volatile organic compounds

[ $\mu \mathrm{g} / \mathrm{L}$, micrograms per liter; ND, not detected; --, no data available]

\begin{tabular}{|c|c|c|c|}
\hline $\begin{array}{l}\text { Compound } \\
\text { (Total) }\end{array}$ & $\begin{array}{c}\text { Number of wells } \\
\text { in which } \\
\text { constituent } \\
\text { was detected }\end{array}$ & $\begin{array}{c}\text { Highest } \\
\text { concentra- } \\
\text { tion } \\
\text { detected, } \\
(\mu \mathrm{g} / \mathrm{L})\end{array}$ & $\begin{array}{c}\text { Well in } \\
\text { which } \\
\text { highest } \\
\text { concentra- } \\
\text { tion was } \\
\text { detected }\end{array}$ \\
\hline Benzene & 10 & 1.7 & $1 N / 4 W-32 D 3$ \\
\hline Bromoform & 3 & 18. & $1 \mathrm{~N} / 4 \mathrm{~W}-16 \mathrm{E} 1$ \\
\hline Carbon tetrachloride & 9 & 13. & $1 \mathrm{~N} / 4 \mathrm{~W}-16 \mathrm{E} 1$ \\
\hline Chlorobenzene & 1 & 4.4 & $1 \mathrm{~N} / 4 \mathrm{~W}-16 \mathrm{E} 1$ \\
\hline Chlorodibromomethane & 1 & 13. & $1 \mathrm{~N} / 4 \mathrm{~W}-16 \mathrm{E} 1$ \\
\hline Chloroethane & 4 & 2.2 & $1 \mathrm{~N} / 4 \mathrm{~W}-32 \mathrm{D} 3$ \\
\hline Chloroform & 25 & 12. & $1 N / 4 W-32 D 3$ \\
\hline Dichlorobromomethane & 2 & 11. & $1 \mathrm{~N} / 4 \mathrm{~W}-16 \mathrm{E} 1$ \\
\hline Dichlorodifluoromethane & 12 & 3.4 & $1 N / 4 W-27 G 1$ \\
\hline Ethylbenzene & 8 & 4. & $1 \mathrm{~N} / 4 \mathrm{~W}-32 \mathrm{D} 3$ \\
\hline Methy1 bromide & 1 & 1.2 & $1 \mathrm{~S} / 3 \mathrm{~W}-17 \mathrm{C} 3$ \\
\hline Methy1 ch1oride & 1 & 0.4 & $1 \mathrm{~N} / 4 \mathrm{~W}-8 \mathrm{P} 1$ \\
\hline Methylene chloride ${ }^{1}$ & 29 & 100. & $1 \mathrm{~S} / 3 \mathrm{~W}-28 \mathrm{H} 1$ \\
\hline Tetrachloroethylene & 17 & 600 & $1 N / 4 W-16 E 4$ \\
\hline Toluene & 14 & 9.2 & $1 \mathrm{~S} / 3 \mathrm{~W}-28 \mathrm{H} 1$ \\
\hline Trichloroethylene & 25 & 86. & $1 \mathrm{~N} / 4 \mathrm{~W}-16 \mathrm{E} 4$ \\
\hline Trichlorofluoromethane & 13 & 12 . & $1 \mathrm{~N} / 4 \mathrm{~W}-27 \mathrm{G1}$ \\
\hline Vinyl chloride & 0 & ND & -- \\
\hline 1,1-Dichloroethylene & 5 & 3.4 & $1 \mathrm{~S} / 3 \mathrm{~W}-23 \mathrm{Al}$ \\
\hline 1,1-Dichloroethane & 7 & 25 . & $1 N / 4 W-16 E 4$ \\
\hline $1,1,1$-Trichloroethane & 6 & 23. & $1 \mathrm{~N} / 4 \mathrm{~W}-16 \mathrm{E} 1$ \\
\hline 1,1,2-Trichloroethane & 0 & ND & $\ldots$ \\
\hline $1,1,2,2$-Tetrachloroethane & 2 & 2. & $1 \mathrm{~S} / 3 \mathrm{~W}-28 \mathrm{H} 1$ \\
\hline 1,2-Dichlorobenzene & 0 & ND & - \\
\hline 1,2-Dichloroethane & 4 & 3. & $1 N / 4 W-32 D 3$ \\
\hline 1,2-Dichloropropane & 2 & 4.5 & $1 \mathrm{~N} / 4 \mathrm{~W}-16 \mathrm{E} 1$ \\
\hline 1,3-Dichloropropene & 0 & ND & -- \\
\hline 1,3 -Dichlorobenzene & 0 & ND & -- \\
\hline 1,2 -transdichloroe thene & 22 & 35 . & $1 N / 4 W-16 E 1$ \\
\hline 2-Chloroethy 1 viny 1 ether & 0 & ND & - \\
\hline 1,4-Dichlorobenzene & 0 & ND & -- \\
\hline trans-1,3-Dichloropropene & 0 & ND & -- \\
\hline cis-1,3-Dichloropropene & 0 & ND & -- \\
\hline
\end{tabular}

${ }^{1}$ Significant concentrations of methylene chloride probably are attributable to laboratory contamination. 


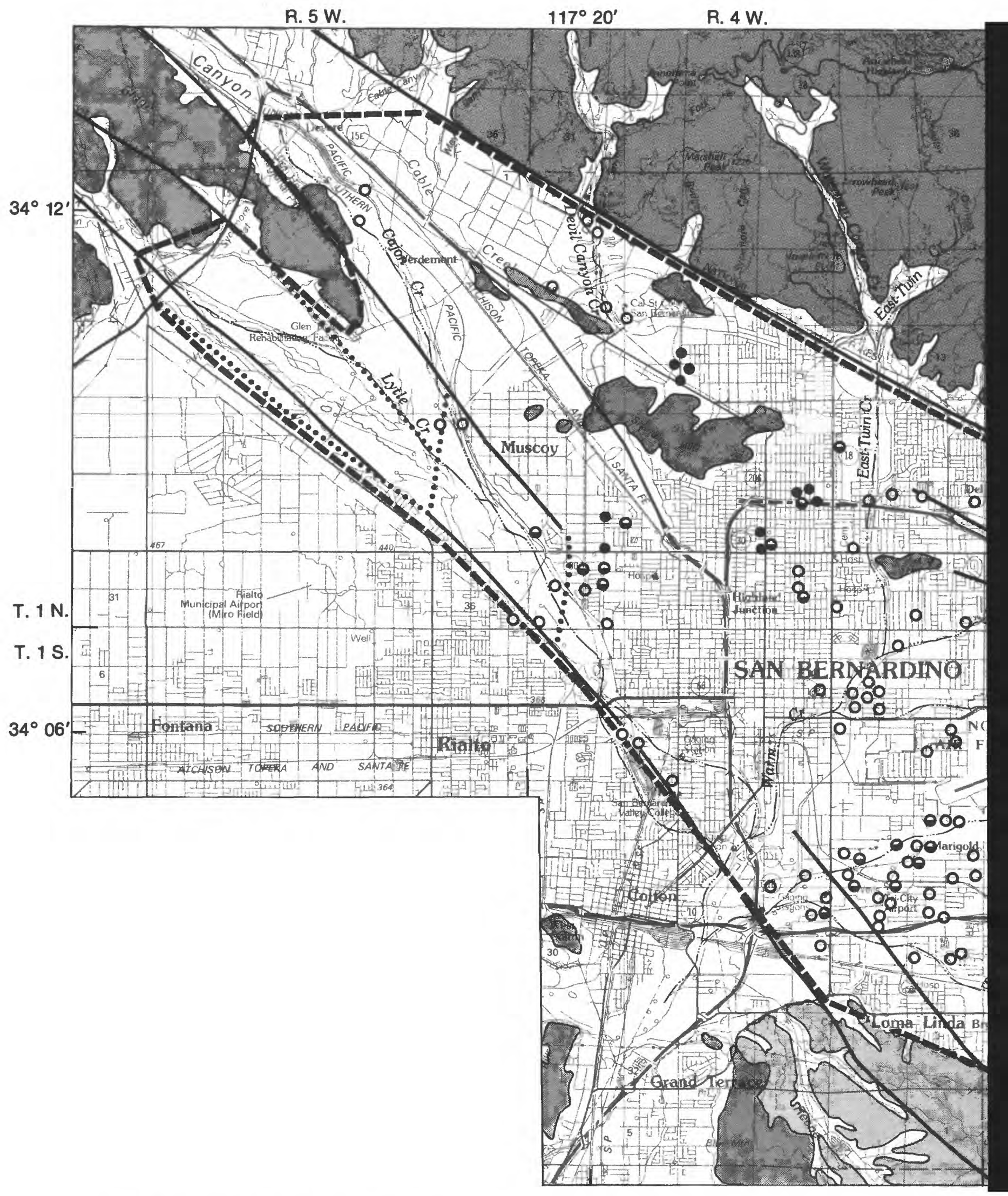

FIGURE 13.--Tetrachloroethylene concentration in water from selected wells, 1984-86. 


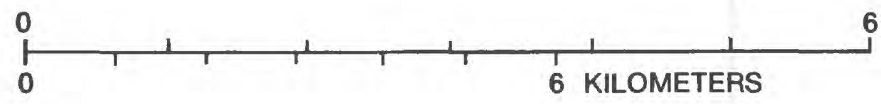

R 3 W $117^{\circ} 10^{\prime}$

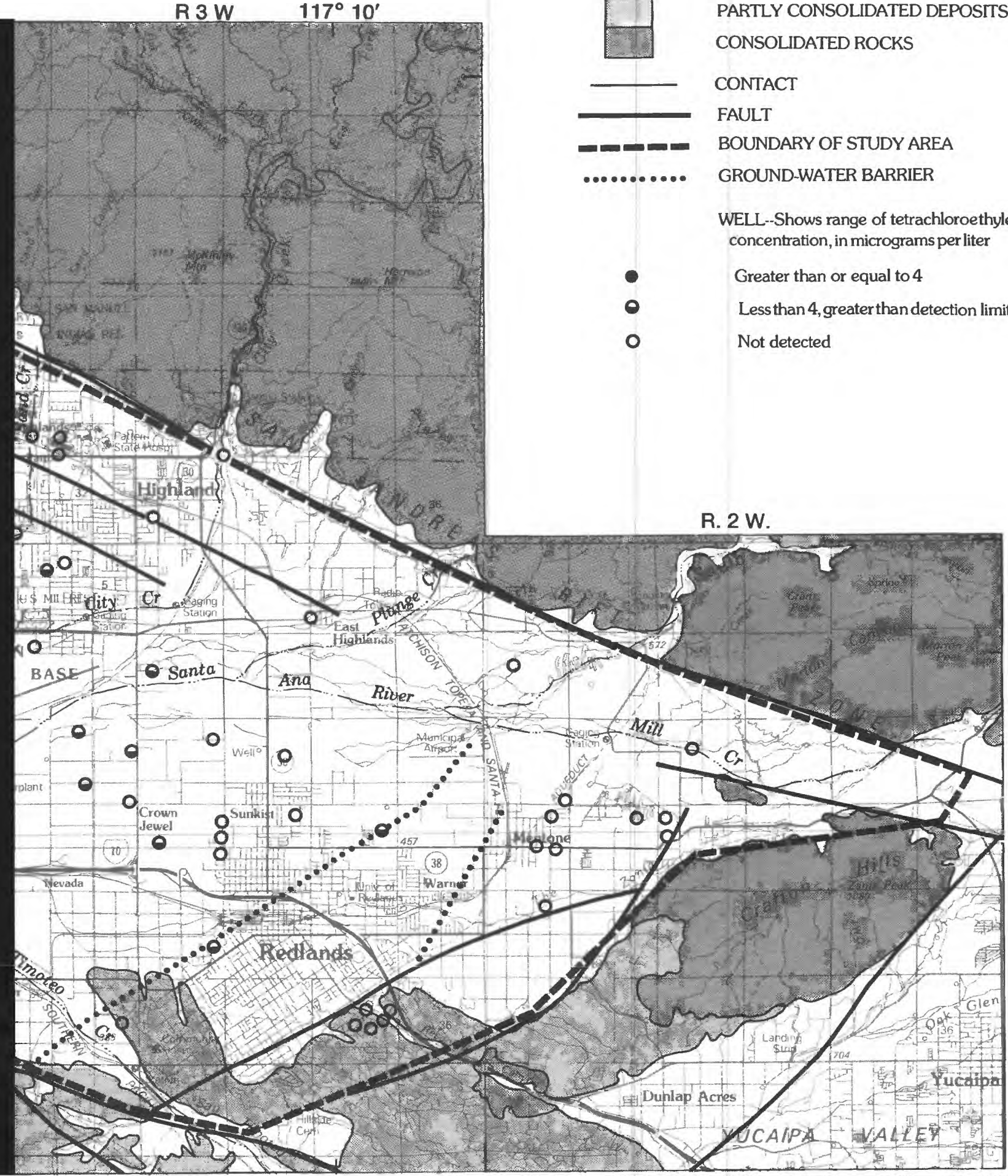

Geology modified from Dibblee $(1963,1968)$ and Dutcher and Garrett $(1963)$

\section{EXPLANATION}

UNCONSOLIDATED DEPOSITS

PARTLY CONSOLIDATED DEPOSITS

CONSOLIDATED ROCKS

CONTACT

BOUNDARY OF STUDY AREA

WELL-Shows range of tetrachloroethylene

Less than 4 , greater than detection limit
Not detected

R. 2 W. 


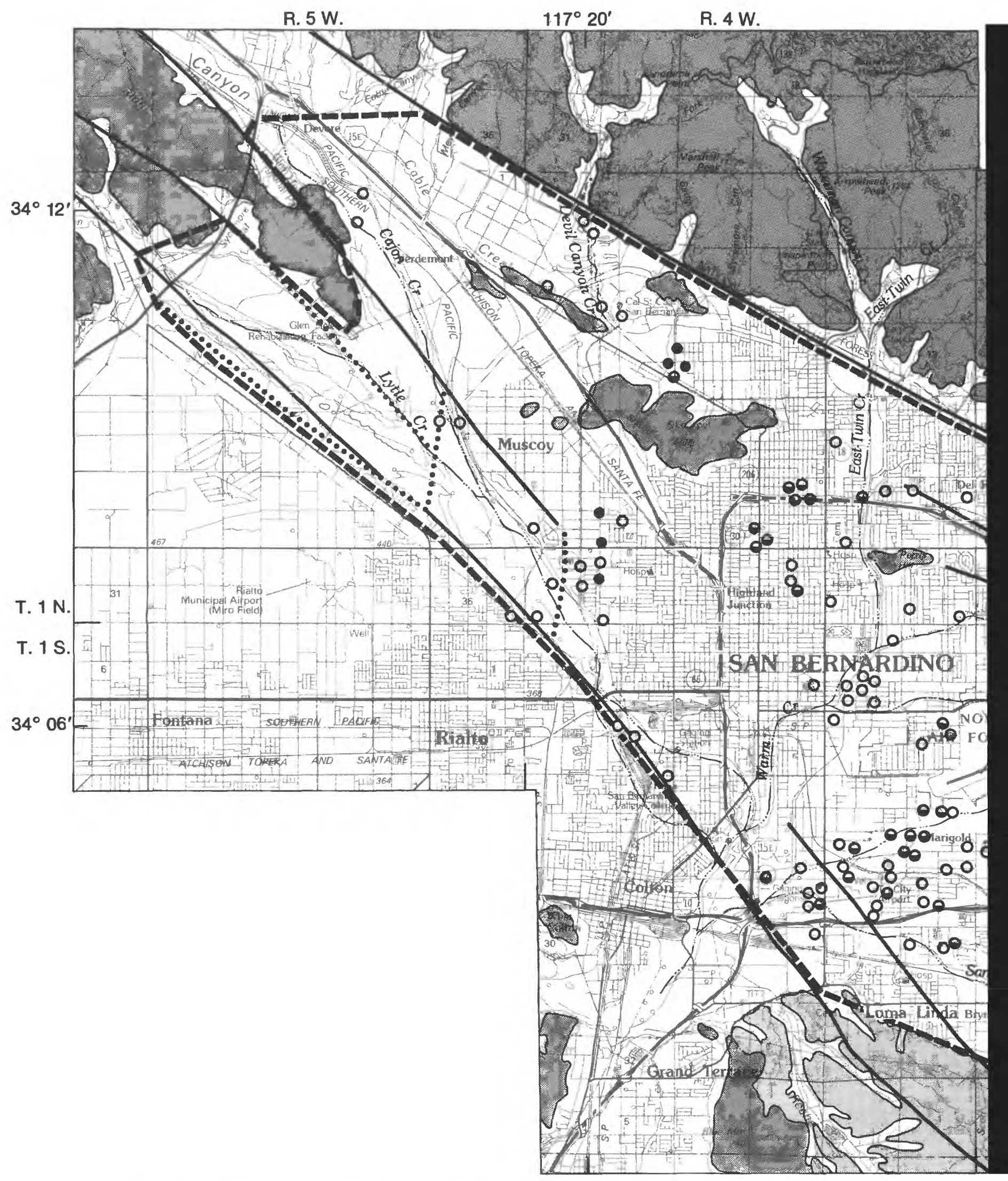

FIGURE 14.--Trichloroethylene concentration in water from selected wells, 1984-86. 
1
6 MILES

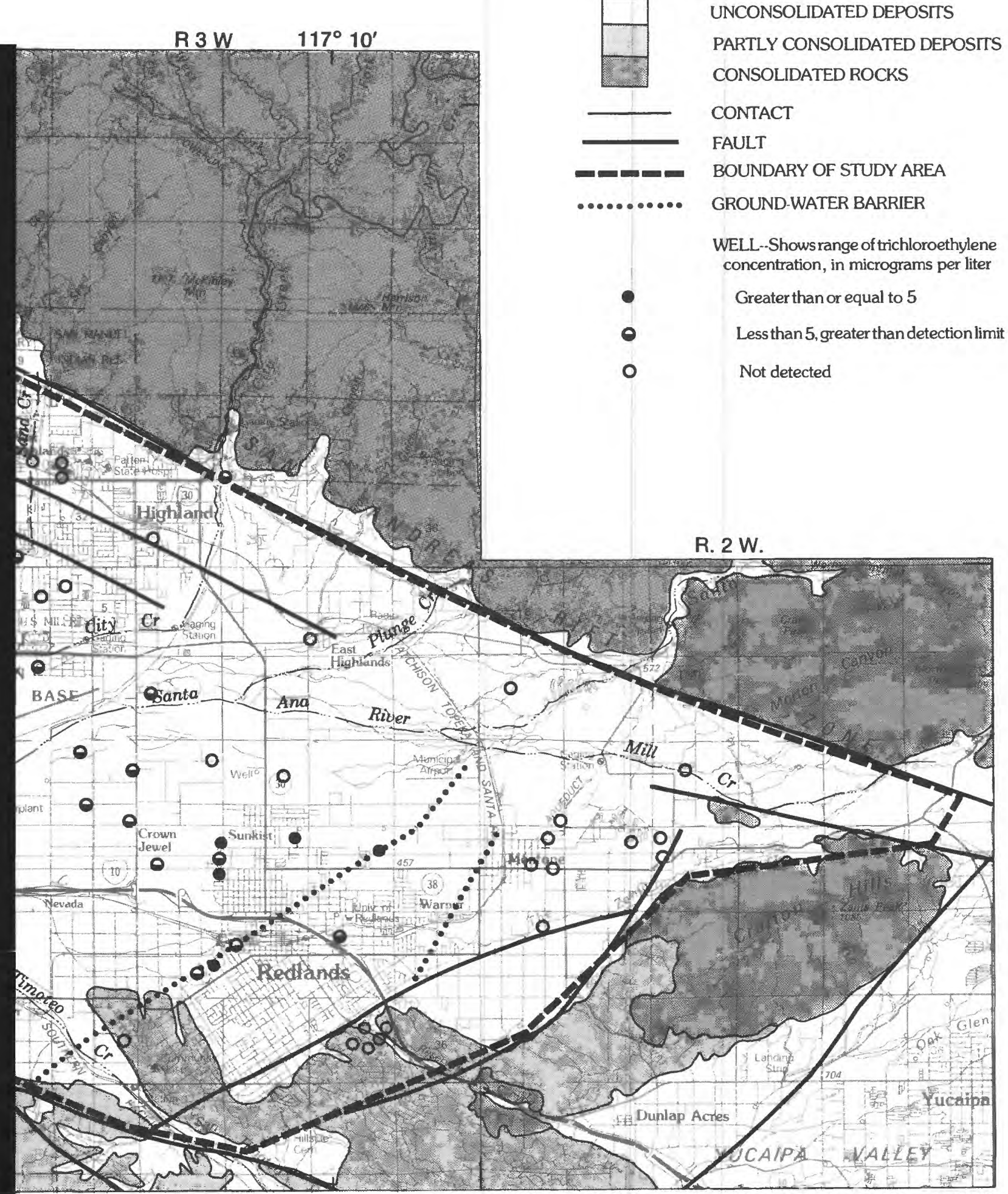

Geology modified from Dibblee (1963, 1968) and Dutcher and Garrett (1963) 
Relation to Land Use and Aquifer

The contingency table of frequency-distribution statistical procedure described in a preceding section was used to test for a relation between PCE and TCE concentrations and land use or aquifer (table 4) in ground water from 39 wells sampled by the U.S. Geological Survey. A binary system was used to classify concentration data as either present (greater than detection limit) or not present (less than detection 1imit). The detection limit was 0.2 $\mu \mathrm{g} / \mathrm{L}-$-except for the samples from eight wells, for which it was $3.0 \mu \mathrm{g} / \mathrm{L}$. Of these eight we1ls, three were resampled and analyzed at the lower limit, three showed the detection of PCE or TCE at the higher limit, and two showed no detection of PCE or TCE at the higher limit. Land use and aquifer open to perforations (sampled) are given in table 4. Results of the statistical test showed no significant correlation between the presence of PCE or TCE and land use or the aquifer sampled. Absence of a correlation with land use is consistent with the existence of many small point sources. Absence of correlation with the aquifer perforated was not expected and is not easily explained. It suggests that contaminants may reach deeper zones through cross-contamination between aquifers in wells with long perforation intervals or through downward leakage around the well casing as a result of poorly constructed seals. However, it also is possible that the number of adequately characterized wells may be too small to yield a reliable conclusion.

NEED FOR OBSERVATION-WELL NETWORK

On the basis of results of this study and published information from previous studies, a network of observation wells that could be used to monitor changes in ground-water quality of the Bunker Hill basin is described. Location of wells in the network and the basis for their selection are given in table 9. Existing wells were chosen wherever possible because of the cost involved in drilling and installing new wells. In two areas of the basin, however, suitable wells are not known to exist. The 40-acre subdivision (specified by township, range, and section) where these wells could be located is given in table 9 .

A total of 11 wells, 9 of which already exist, are in the observationwell network. Wells could be sampled every 6 months, preferably in early autumn after the dry season and in early spring after the wet season, and analyzed for the same constituents that were determined in this study (1isted in table 2); sampling for analysis for DBCP could be included. Operation of this network would provide a timely mechanism for monitoring trends in the quality of ground water in the basin. In addition, if the 47 wells sampled for this study were resampled once approximately every 5 years, the results could be used to provide information about any possible adverse changes of the resource and to optimize management of ground water in the basin. 
Table 9.--Wells and locations for potential ground-water quality observation-well network

\begin{tabular}{|c|c|c|c|c|}
\hline $\begin{array}{l}\text { Well No. } \\
\text { or } \\
\text { location }\end{array}$ & $\begin{array}{l}\text { Perforation } \\
\text { interval, } \\
\text { in feet } \\
\text { below land } \\
\text { surface }\end{array}$ & $\begin{array}{l}\text { Description } \\
\text { of aquifer } \\
\text { perforated }\end{array}$ & $\begin{array}{l}\text { Recharge } \\
\text { source }\end{array}$ & Reason to monitor \\
\hline $\begin{array}{l}\text { 1N/ } 4 \mathrm{~W}-22 \mathrm{~B} \\
\text { (suggested } \\
\text { location) }\end{array}$ & $350-400$ & $\begin{array}{l}\text { No confine- } \\
\text { ment }\end{array}$ & Northwest & $\begin{array}{l}\text { To determine if PCE and TCE are present in } \\
\text { the ground water. To detect movement } \\
\text { of PCE and TCE from the northwest. }\end{array}$ \\
\hline $1 N / 4 W-25 C 2$ & $378-569$ & $\begin{array}{l}\text { No confine- } \\
\text { ment }\end{array}$ & $\begin{array}{l}\text { North and } \\
\text { northwest }\end{array}$ & $\begin{array}{l}\text { To detect movement of PCE and TCE from the } \\
\text { northwest and nitrate-nitrogen from the } \\
\text { surrounding areas. }\end{array}$ \\
\hline $1 N / 4 W-34 G 1$ & $\begin{array}{l}494-572 \\
577-670\end{array}$ & Lower & Northwest & $\begin{array}{l}\text { To detect movement of PCE and TCE from the } \\
\text { north and northwest. Represents water } \\
\text { recharging the lower aquifer. }\end{array}$ \\
\hline $1 \mathrm{~S} / 3 \mathrm{~W}-9 \mathrm{E} 2$ & $\begin{array}{l}211-288 \\
315-320 \\
355-385\end{array}$ & $\begin{array}{l}\text { Both } \\
\text { aquifers }\end{array}$ & East & $\begin{array}{l}\text { Represents water from the Santa Ana River } \\
\text { recharging the upper and lower aquifers. } \\
\text { PCE and TCE previously detected. }\end{array}$ \\
\hline $1 S / 3 W-17 C 3$ & $105-255$ & Upper & $\begin{array}{l}\text { East and } \\
\text { south }\end{array}$ & $\begin{array}{l}\text { To detect movement of PCE, TCE, and nitrate- } \\
\text { nitrogen from the southeast. }\end{array}$ \\
\hline $\begin{array}{l}\text { 1S/3W-17M } \\
\text { (suggested } \\
\text { location) }\end{array}$ & $200-250$ & Upper & $\begin{array}{l}\text { East and } \\
\text { south }\end{array}$ & $\begin{array}{l}\text { To determine if PCE and TCE are found in } \\
\text { the upper aquifer in this area. To } \\
\text { detect movement of PCE and TCE from the } \\
\text { east. }\end{array}$ \\
\hline $1 S / 3 W-18 N 2$ & $793-988$ & Lower & East & $\begin{array}{l}\text { To detect movement of PCE, TCE, or nitrate- } \\
\text { nitrogen into the lower aquifer from the } \\
\text { east. }\end{array}$ \\
\hline $1 S / 4 W-11 D 2$ & $888-951$ & Lower & North & $\begin{array}{l}\text { To detect movement of PCE, TCE, or nitrate- } \\
\text { nitrogen into the lower aquifer from the } \\
\text { north. }\end{array}$ \\
\hline $1 S / 4 W-13 N 1$ & $122-299$ & Upper & $\begin{array}{l}\text { East and } \\
\text { north }\end{array}$ & $\begin{array}{l}\text { To detect changes occurring to the upper } \\
\text { aquifer. }\end{array}$ \\
\hline $1 \mathrm{~S} / 4 \mathrm{~W}-22 \mathrm{H} 2$ & $1,008-1,088$ & Lower & $\begin{array}{l}\text { Northeast } \\
\text { and north }\end{array}$ & $\begin{array}{l}\text { To detect changes occurring to the deeper } \\
\text { part of the lower aquifer. }\end{array}$ \\
\hline $1 S / 4 W-23 A 5$ & $\begin{array}{l}518-575 \\
636-700\end{array}$ & Lower & $\begin{array}{l}\text { East and } \\
\text { north }\end{array}$ & $\begin{array}{l}\text { To detect changes occurring to the upper } \\
\text { part of the lower aquifer. }\end{array}$ \\
\hline
\end{tabular}

\section{SUMMARY AND CONCLUSIONS}

Land use in the 120 -square-mile Bunker Hill basin is rapidly changing from agriculture to urban, and ground-water-quality problems have become an important concern to the residents and to water-supply agencies. Nitrate and purgeable (volatile) organic priority pollutants are contaminants that have been detected previously in the basin's ground water. To address this concern, 47 wells were sampled for this study, and samples of water from 46 of the wells were analyzed for major inorganic ions, samples from all 47 wells were analyzed for nitrogen species, and samples from 45 were analyzed for volatile organic compounds. Nitrate, PCE, and TCE data collected by other agencies from additional wells were used to supplement the data obtained in this study. 
The inorganic quality of ground water in the basin generally is suitable for most uses. The water generally is of a sodium calcium bicarbonate type, containing about equal amounts (on an equivalents basis) of sodium and calcium in water near the surface and an increasing predominance of sodium in water of the lower aquifer. Mean dissolved-solids concentration was about $400 \mathrm{mg} / \mathrm{L}$ in the upper aquifer and about $200 \mathrm{mg} / \mathrm{L}$ in the lower aquifer in the central part of the basin where the lower aquifer is confined. Fluoride concentrations that exceed California's public drinking-water standard of $1.4 \mathrm{mg} / \mathrm{L}$ were detected in water from five wells; the maximum concentration that was measured is $3 \mathrm{mg} / \mathrm{L}$.

Nitrate as nitrogen $\left(\mathrm{NO}_{3}-\mathrm{N}\right)$ concentration equaled or exceeded the public drinking-water standard of $10 \mathrm{mg} / \mathrm{L}$ in water from 13 of 47 wells sampled for this study, and in an additional 19 of 120 wells when wells sampled by other agencies since 1984 are included. No correlation between constituent concentration and land use was apparent; however, concentrations generally decreased with increasing depth below land surface. In the central part of the basin where the lower aquifer is confined, mean $\mathrm{NO}_{3}-\mathrm{N}$ concentration was 14 $\mathrm{mg} / \mathrm{L}$ in the upper aquifer and $3.2 \mathrm{mg} / \mathrm{L}$ in the lower aquifer. No basinwide trend was discerned from a comparison between current and historical nitrate concentrations (dating back as far as 1955) in water from 17 wells.

Twenty-four of the 33 purgeable organic priority pollutants were detected (detection limit of 0.2 or $3.0 \mu \mathrm{g} / \mathrm{L}$ ) in the water from at least 1 of the 45 wells sampled. California has established interim standards (action levels) of $4 \mu \mathrm{g} / \mathrm{L}$ for PCE and $5 \mu \mathrm{g} / \mathrm{L}$ for TCE. PCE and TCE, which are two of the most commonly found organic contaminants in the Bunker Hill basin ground-water system, were detected in water from 20 (for PCE) and 32 (for TCE) of the 45 wells sampled during this study. Water-quality results obtained in this study, in combination with those obtained by other agencies, indicate that PCE concentration exceeded the California interim standard in water from 36 of 134 we1ls, and TCE concentration exceeded the California interim standard in water from 49 of 138 wells. No obvious basinwide pattern of contamination by these two chemicals was apparent, other than their relatively common occurrence in concentrations higher than the California interim standard in the northwest San Bernardino and central Redlands areas.

Water-quality results obtained in this study and published information from other studies were used to describe a potential ground-water-quality observation-well network. The network consists of 11 wells that could be sampled every 6 months. In addition, 47 of the wells sampled in this study could be resampled every 5 years. The water-quality information obtained from the network could be used to determine trends and to identify changes in ground-water quality in the Bunker Hill basin.

\section{REFERENCES CITED}

Brown, D.M., Skougstad, M.W., and Fishman, M.J., 1970, Methods for collection and analysis of water samples for dissolved minerals and gases: U.S. Geological Survey Techniques of Water-Resources Investigations, Book 5, Chapter A1, 160 p. (superseded by Skougstad and others, 1979). 
Burnham, W.L., and Dutcher, L.C., 1960, Geology and ground-water hydrology of the Redlands-Beaumont area, California, with special reference to ground-water outflow: U.S. Geological Survey Open-File Report, 352 p.

California Department of Health, 1977, California domestic water quality and monitoring regulations [Excerpts from the California Health and Safety Code and the California Administrative Code, Title 22], 23 p.

California Department of Water Resources, 1985, Upper Santa Ana River drainage area land-use survey, 1984: Southern District, $19 \mathrm{p}$.

Conover, W.J., 1980, Practical nonparametric statistics, 2d edition: New York, John Wiley, $493 \mathrm{p}$.

Dibblee, T.W., Jr., 1963, Geologic map of the San Bernardino quadrangle: U.S. Geological Survey Open-File Map, scale 1:62,500.

-... 1968, Geologic map of the Redlands quadrangle: U.S. Geological Survey Open-File Map, scale 1:62,500.

Dutcher, L.C., and Garrett, A.A., 1963, Geologic and hydrologic features of the San Bernardino area, California, with special reference to underflow across the San Jacinto fault: U.S. Geological Survey Water-Supply Paper $1419,114 \mathrm{p}$.

Eccles, L.A., 1979, Ground-water quality in the upper Santa Ana River basin, southern California: U.S. Geological Survey Water-Resources Investigations Report 79-113, 51 p.

Eccles, L.A., and Bradford, W.L., 1977, Distribution of nitrate in ground water, Redlands, California: U.S. Geological Survey Water-Resources Investigations Report 76-117, $38 \mathrm{p}$.

Eccles, L.A., and Klein, J.M., 1978, Distribution of dissolved nitrate and fluoride in ground water, Highland-East Highlands, San Bernardino County, California: U.S. Geological Survey Water-Resources Investigations Report $78-14,42 \mathrm{p}$.

Hardt, W.F., and Freckleton, J.R., 1987, Aquifer response to recharge and pumping, San Bernardino ground-water basin, California: U.S. Geological Survey Water-Resources Investigations Report 86-4140, 69 p.

Hardt, W.F., and Hutchinson, C.B., 1980, Development and use of a mathematical model of the San Bernardino Valley ground-water basin, California: U.S. Geological Survey Open-File Report 80-576, 80 p.

Helse1, D.R., and Ragone, S.E., 1984, Evaluation of regional ground-water quality in relation to land use: U.S. Geological Survey Water-Resources Investigations Report 84-4217, $33 \mathrm{p}$.

Klein, J.M., and Bradford, W.L., 1979, Distribution of nitrate and related nitrogen species in the unsaturated zone, Redlands and vicinity, San Bernardino County, California: U.S. Geological Survey Water-Resources Investigations Report 79-60, 81 p.

-... 1980, Distribution of nitrate in the unsaturated zone, Highland-East Highlands area, San Bernardino County, California: U.S. Geological Survey Water-Resources Investigations Report 80-48, $70 \mathrm{p}$.

Skougstad, M.W., Fishman, M.J., Friedman, L.C., Erdmann, D.E., and Duncan, S.S., 1979, Methods for determination of inorganic substances in water and fluvial sediments: U.S. Geological Survey Techniques of Water-Resources Investigations, Book 5, Chapter A1, 626 p.

URS Corporation, 1986, Investigation of sources of TCE and PCE contamination in the Bunker Hill ground water basin: submitted to California Regional Water Quality Control Board, Santa Ana Region, 108 p. 


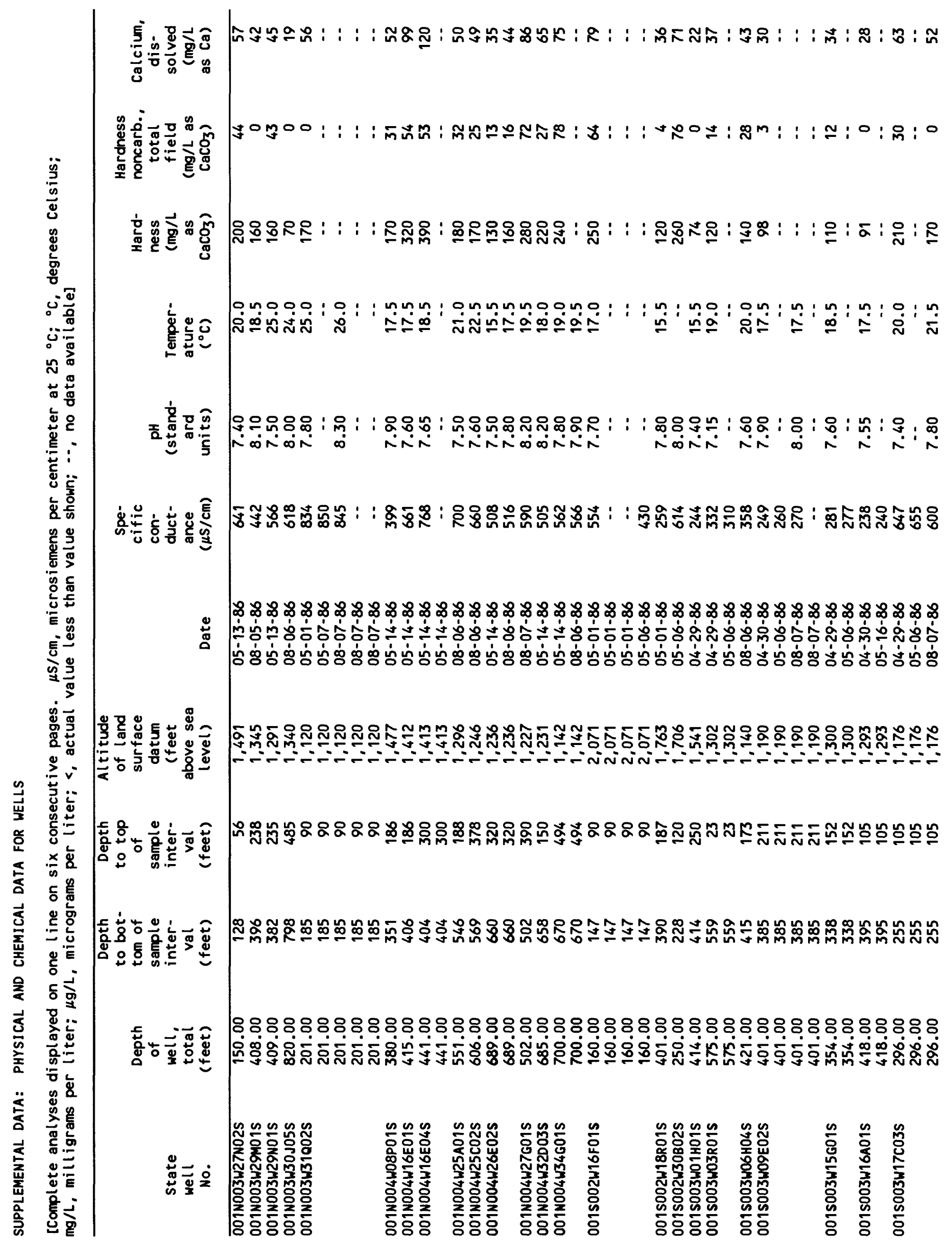




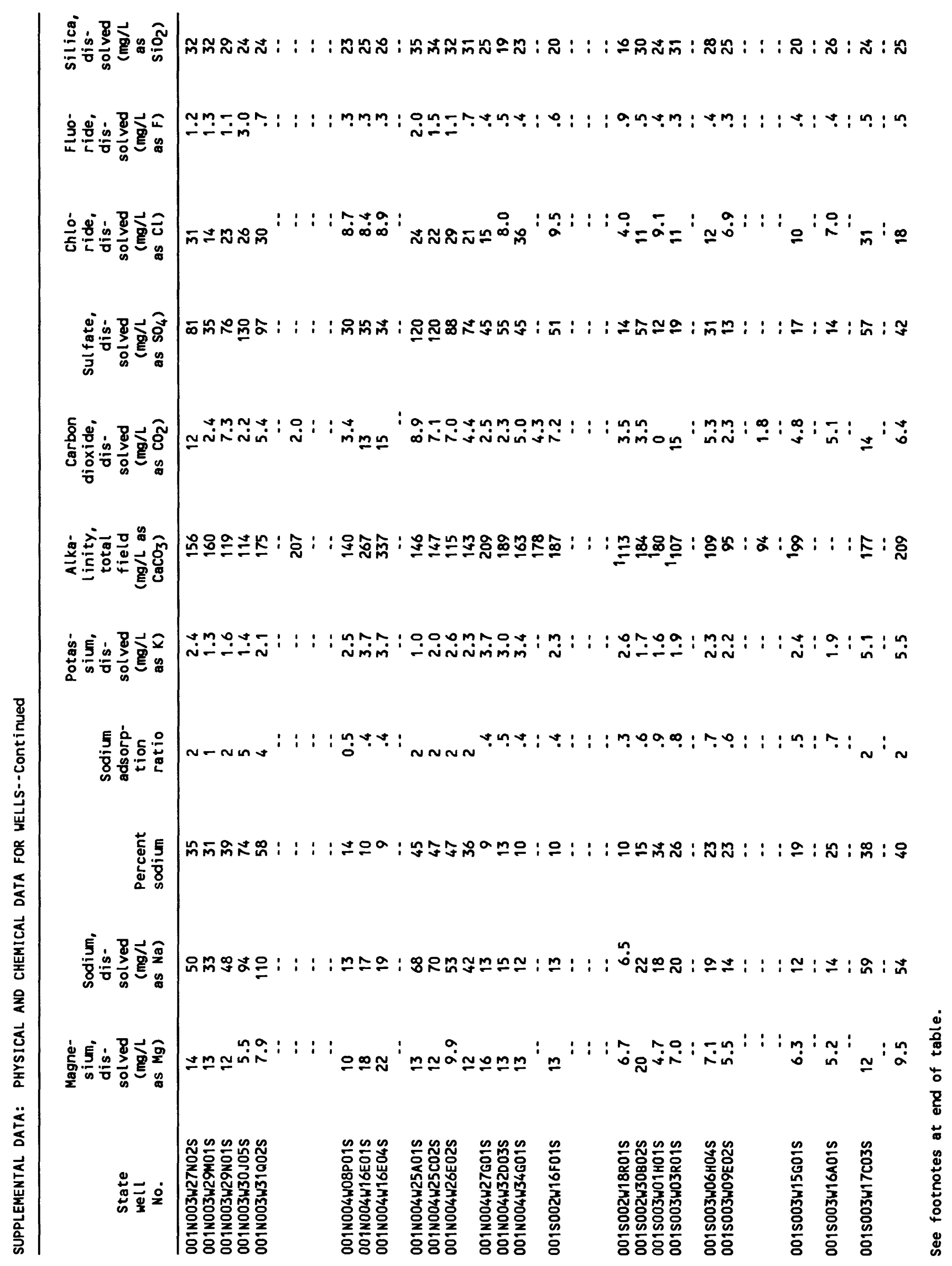




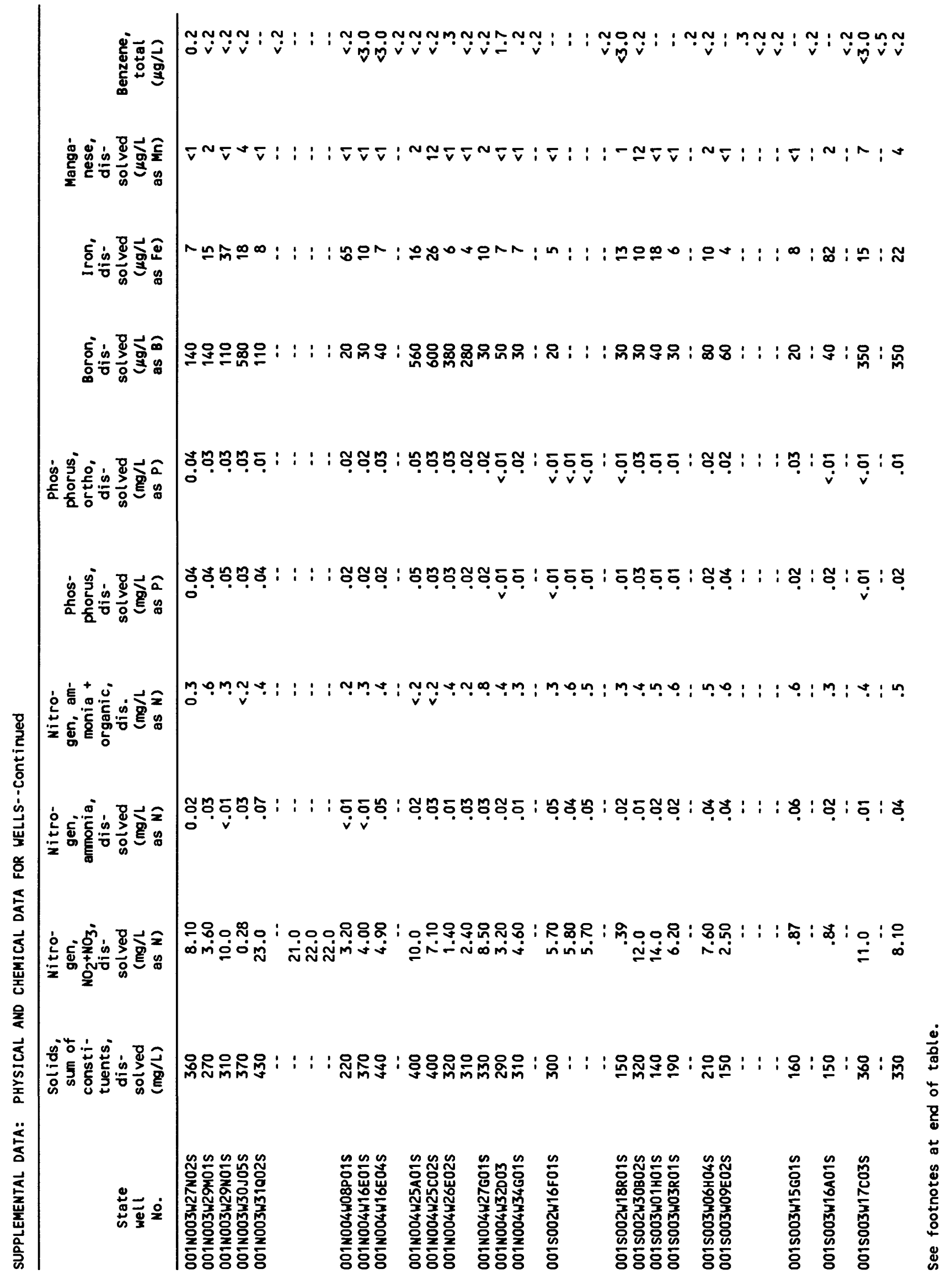




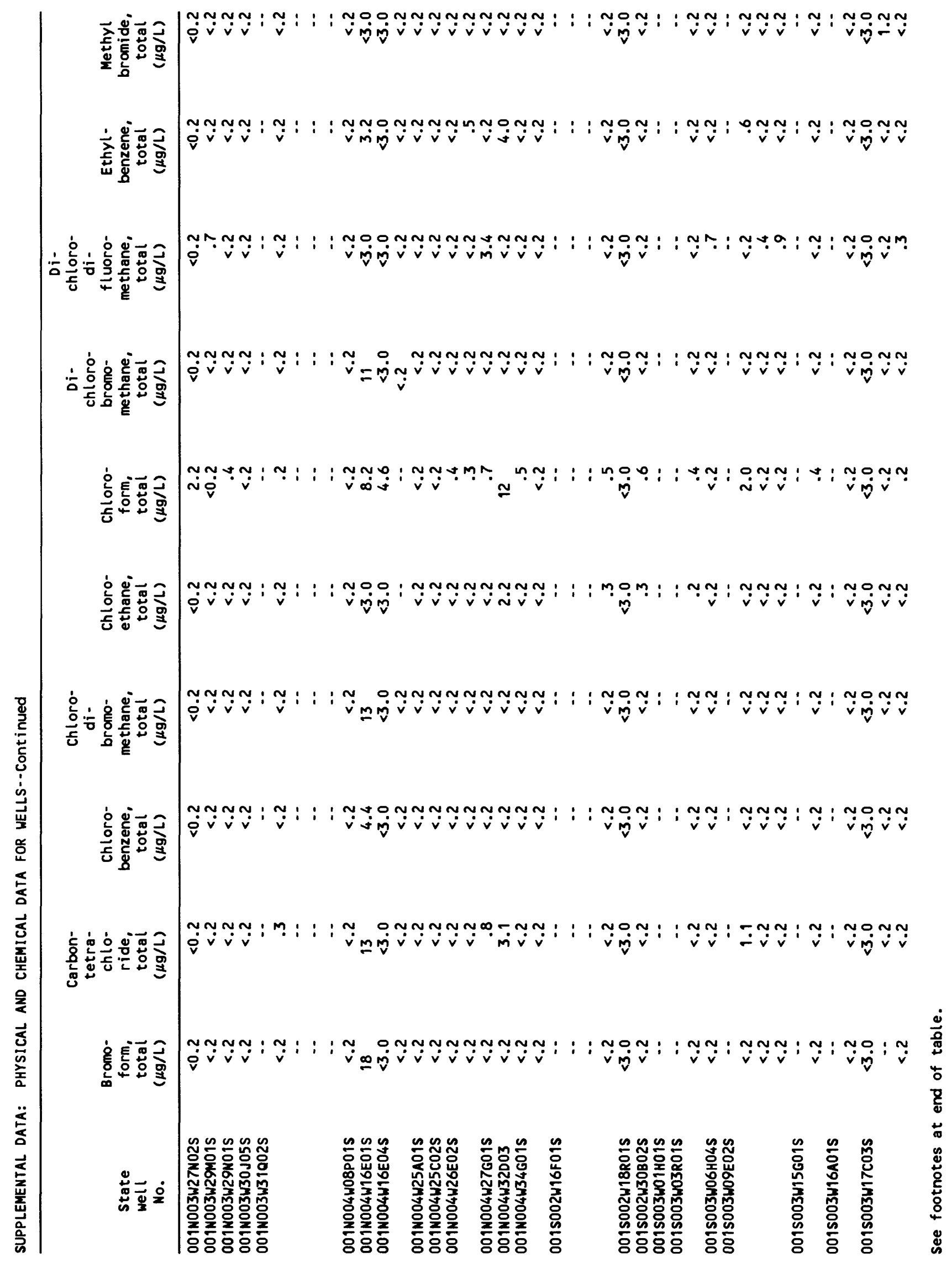




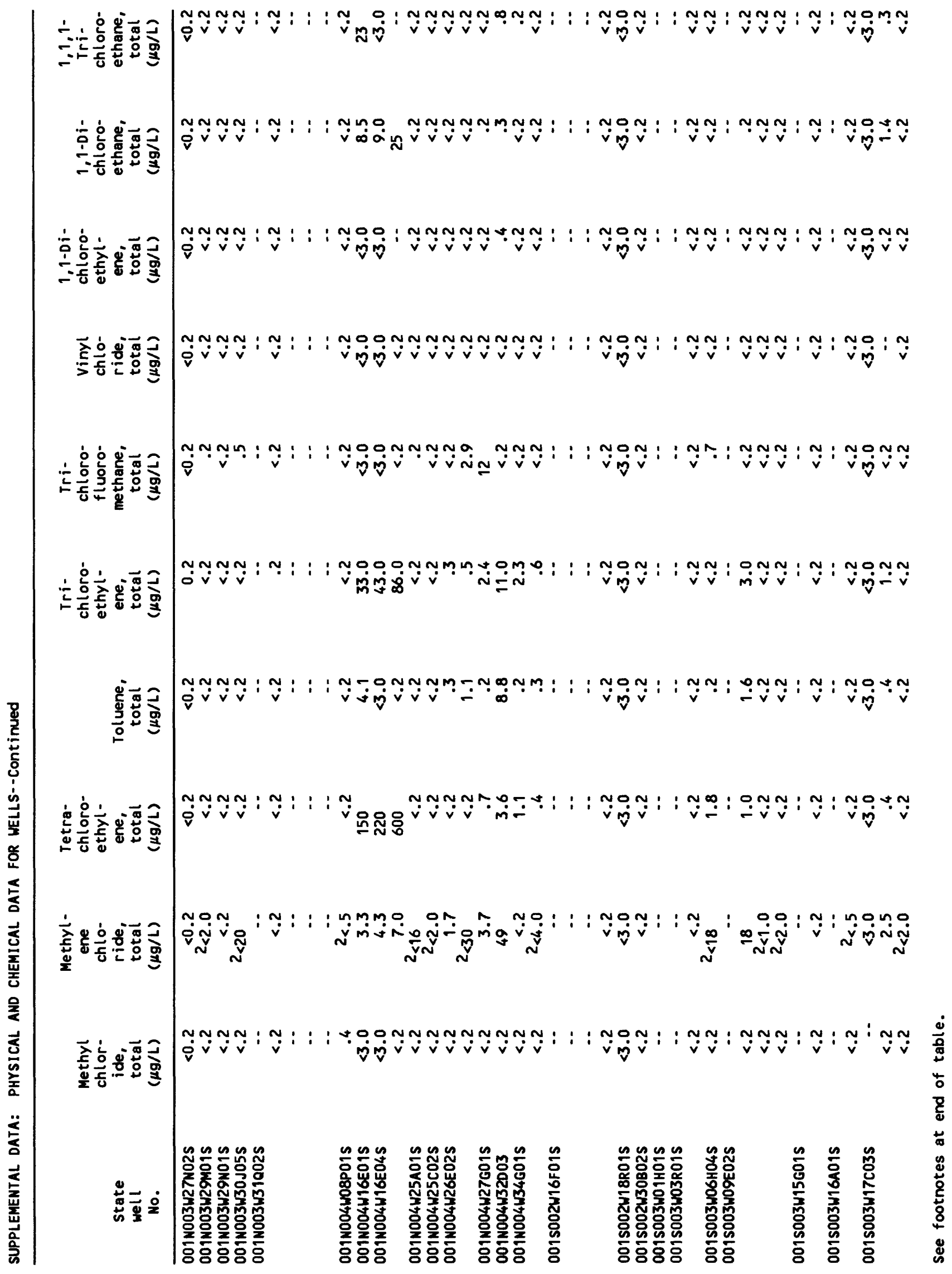




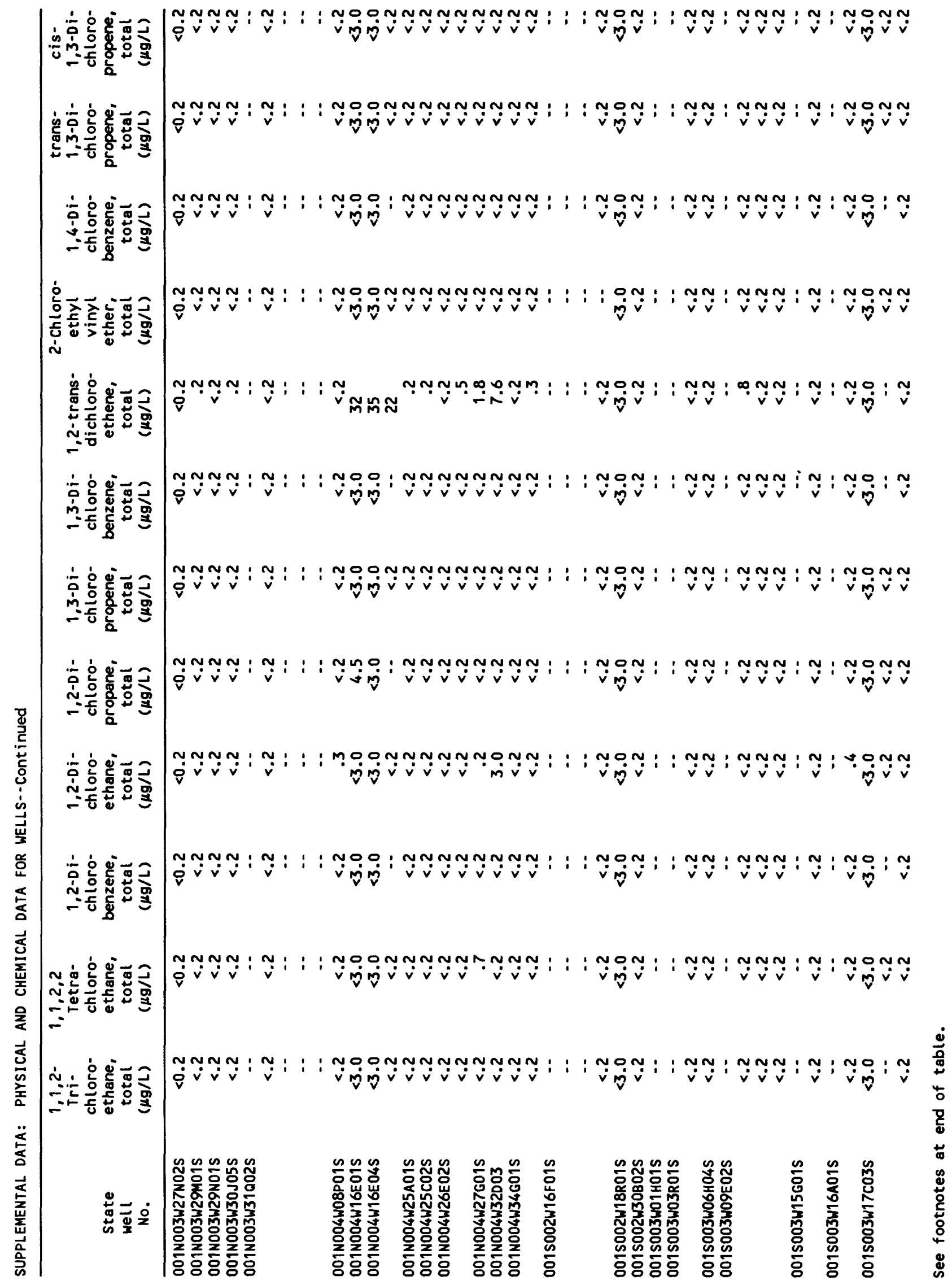




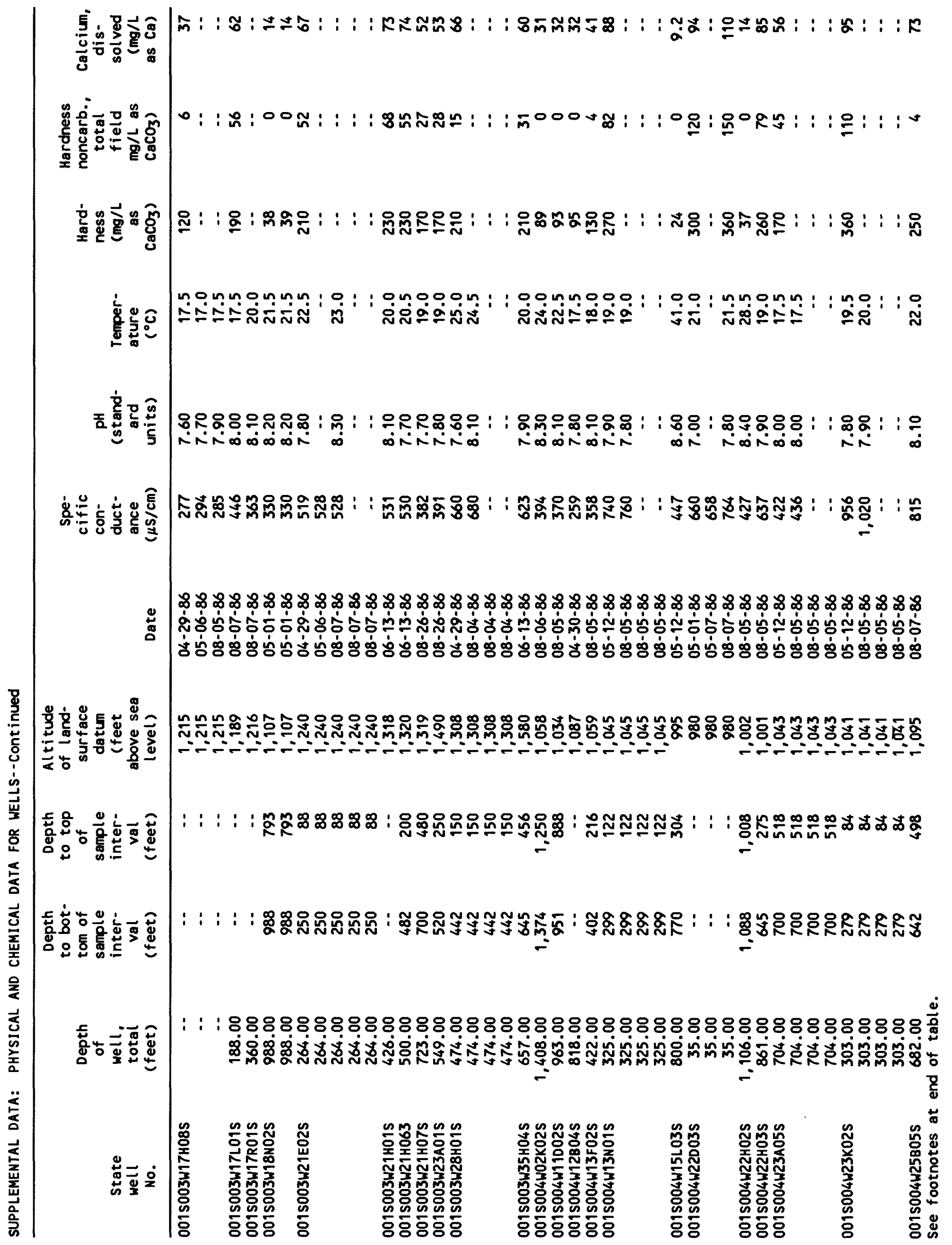




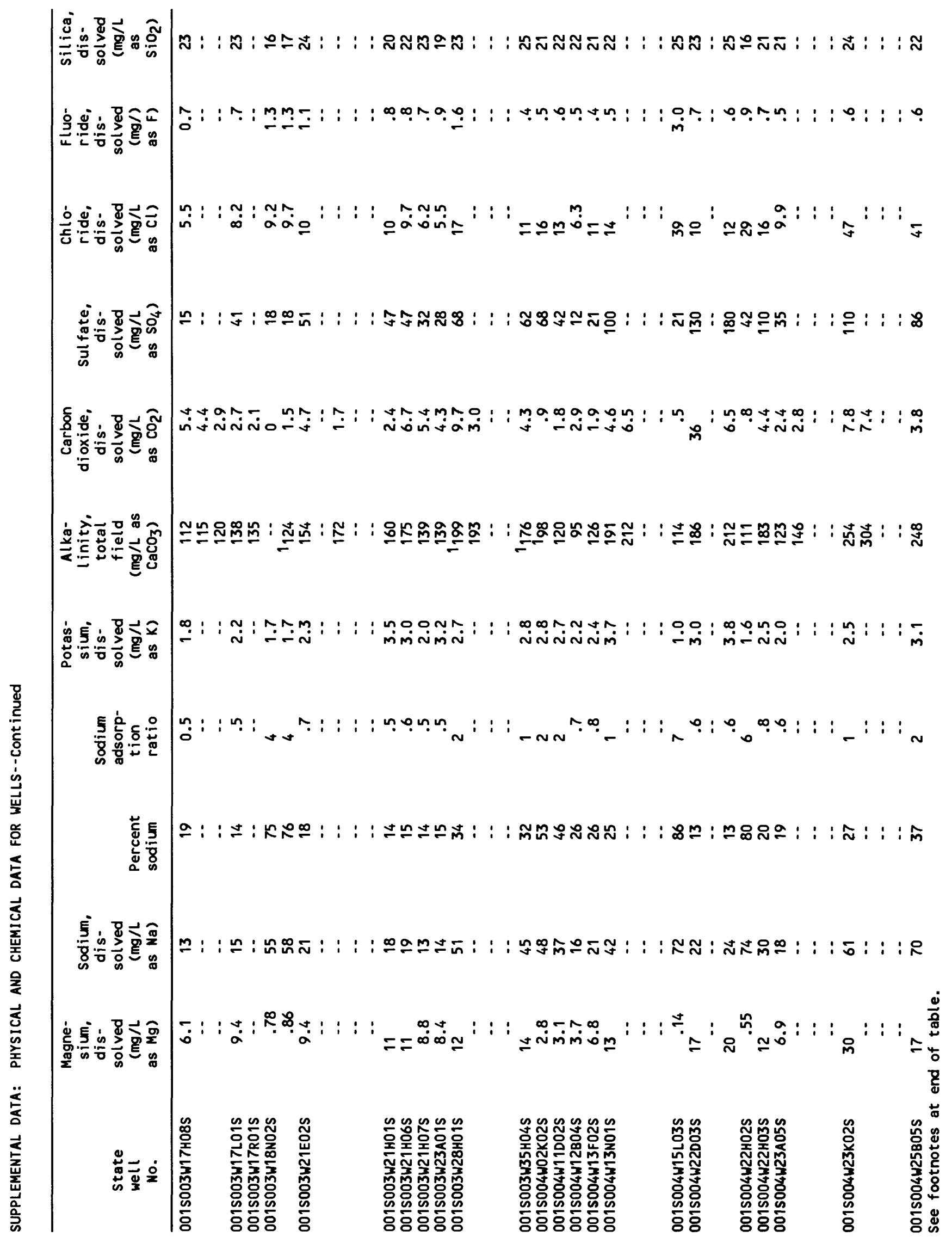




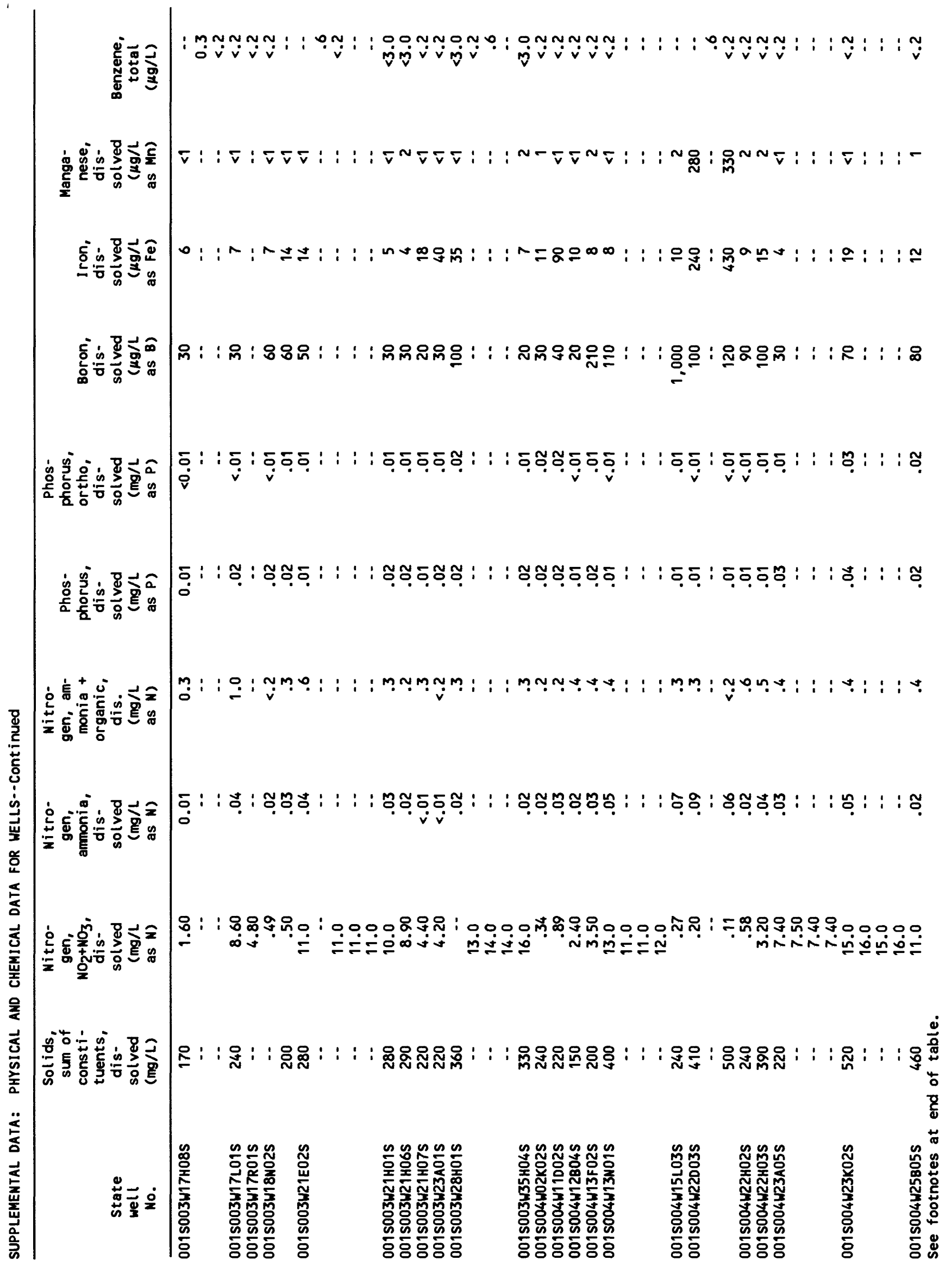




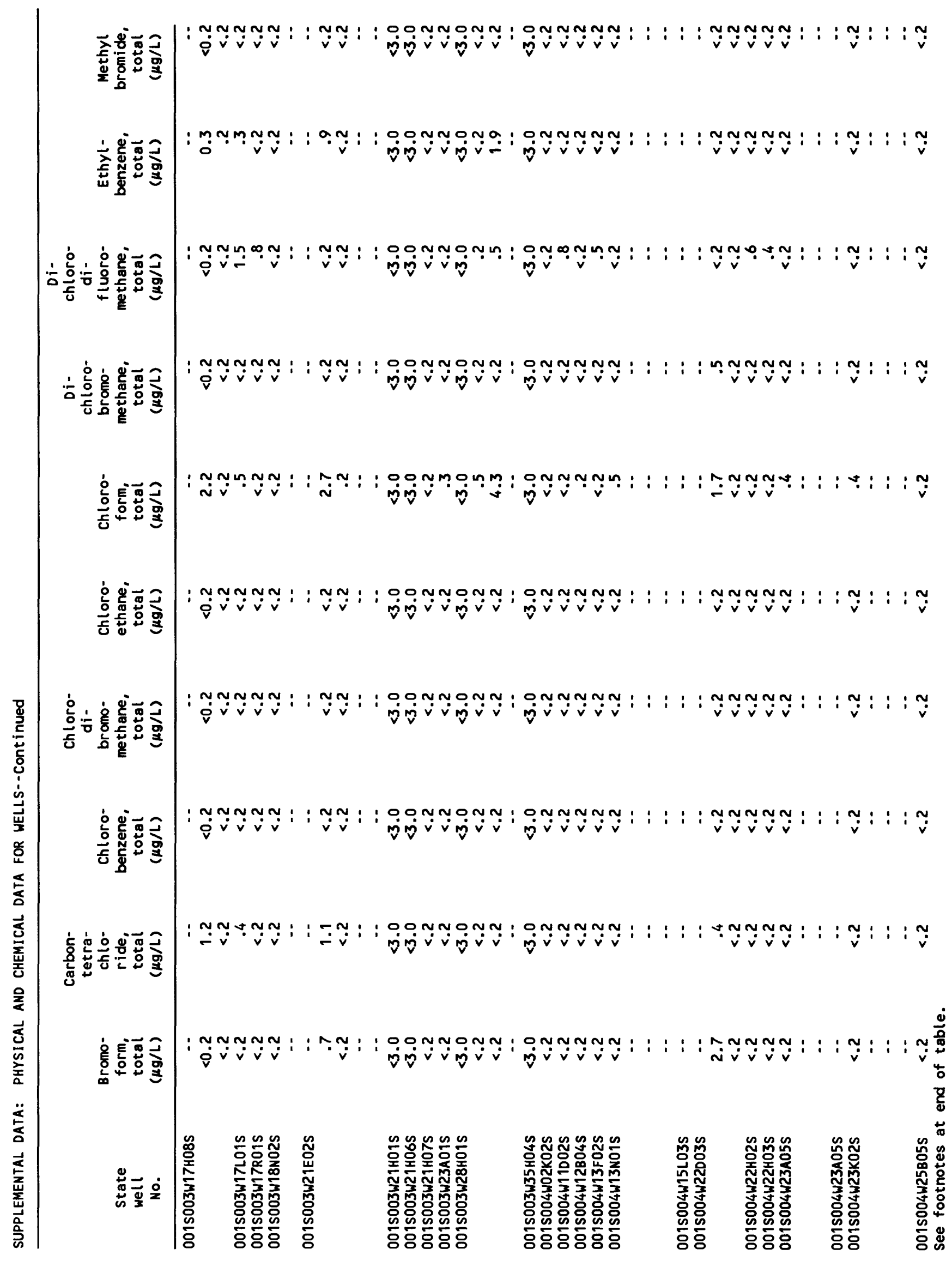




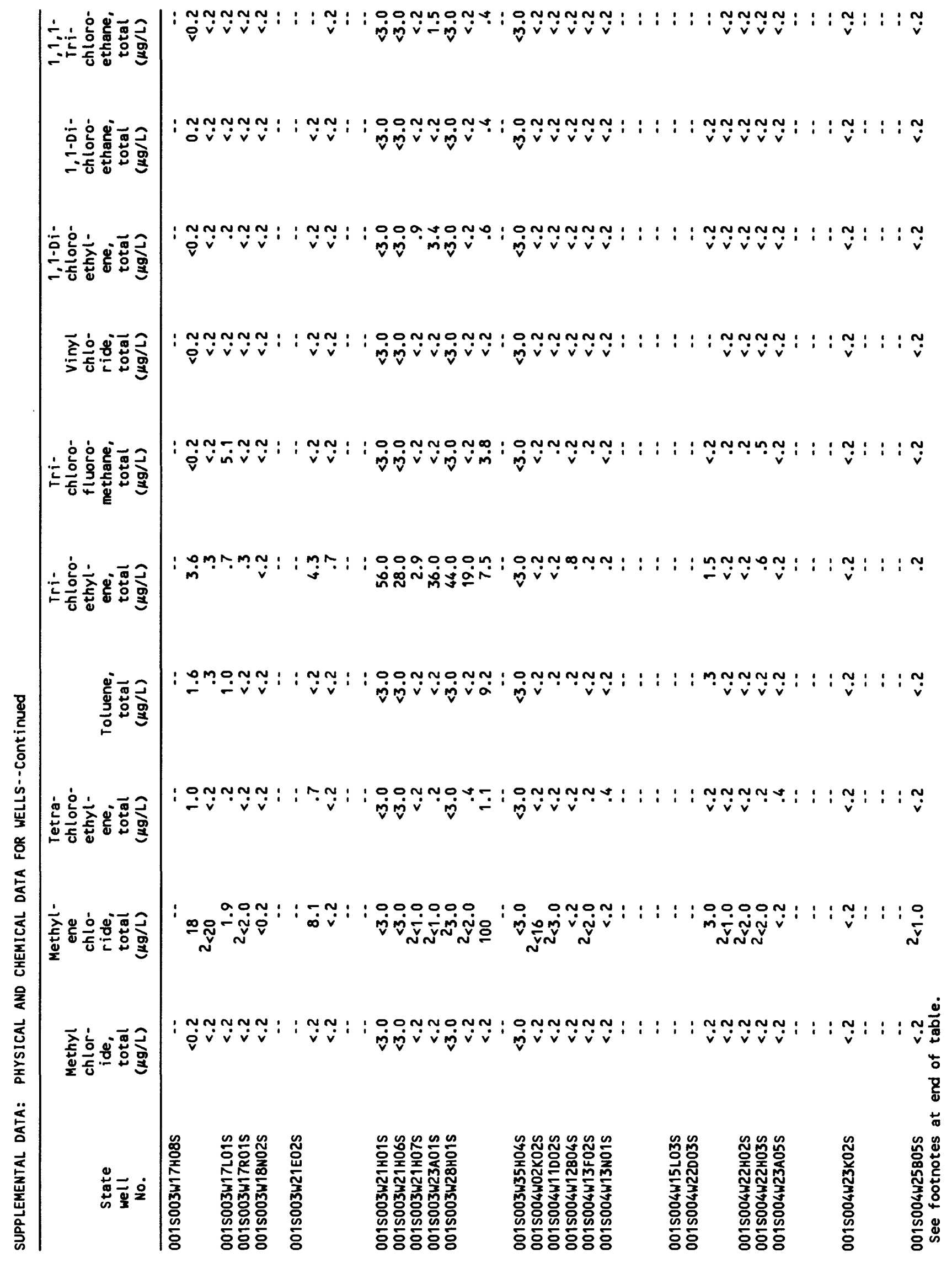

